\author{
Nevada \\ Environmental \\ Restoration \\ Project
}

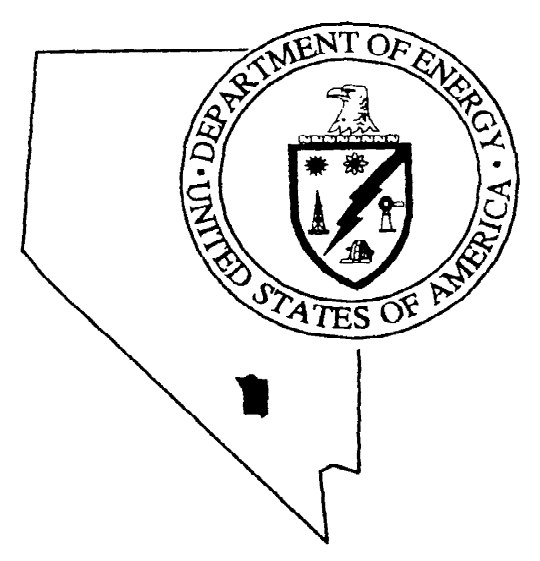

\title{
Recompletion Report for Well UE-10j
}

May 2000

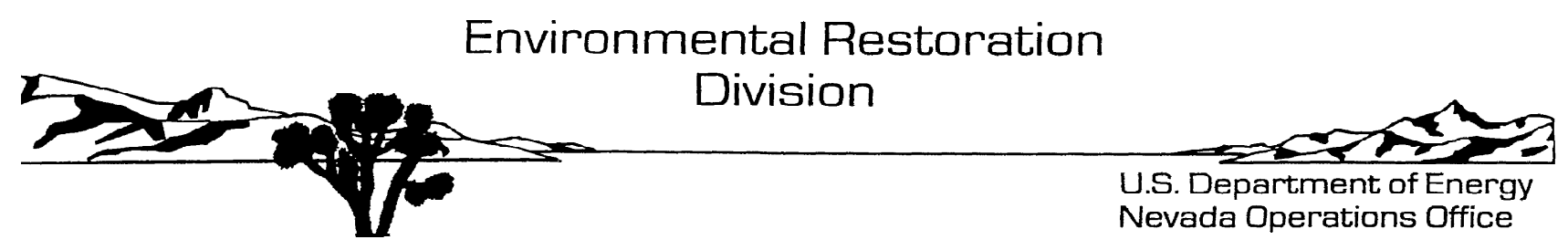




\section{DISCLAIMER STATEMENT}

Reference herein to any specific commercial product, process, or service by trade name, trademark, manufacturer, or otherwise, does not necessarily constitute or imply its endorsement, recommendation, or favoring by the U.S. Government or any agency thereof or its contractors or subcontractors.

\section{AVAILABILITY STATEMENT}

Available for sale to the public from:

U.S. Department of Commerce

National Technical Information Service

5285 Port Royal Road

Springfield, VA, 22161-0002

Telephone: $800-553-6847$ or 703-605-6000

Fax: 703-605-6900

E-mail: orders@ntis.fedworld.gov

Online ordering: http://www.ntis.gov/ordering.htm

Available electronically at http://www.doe.gov/bridge

Available for a processing fee to U.S. Department of Energy and its contractors, in paper, from:

U.S. Department of Energy

Office of Scientific and Technical Information

P.O. Box 62

Oak Ridge, TN, 37831-0062

Telephone: 865-576-8401

Fax: 865-576-5728

E-mail: reports@adonis.osti.gov 


\title{
Recompletion Report for Well UE-10j
}

\author{
Prepared for: \\ U. S. Department of Energy \\ Nevada Operations Office \\ Las Vegas, Nevada \\ Prepared by: \\ Bechtel Nevada \\ Geotechnical Services \\ Las Vegas, Nevada
}

May 2000

Work performed under Contract No. DE-AC08-96NV11718 
This page intentionally left blank. 
DOE/NV/11718--414

\section{RECOMPLETION REPORT FOR WELL UE-10j}

Approved by: Robent M. Bangesters In.

Date: $5 / 30 / 00$

Robert M. Bangerter, Project Manager,

Underground Test Area Project

Approved by: Reusee Shyedy

Date: $5 / 30 / 00$

Environmental Restoration Division 
This page intentionally left blank. 


\title{
Recompletion Report for Well UE-10j \\ DOE/NV/11718--414
}

\begin{abstract}
Existing Well UE-10j was deepened and recompleted for the U.S. Department of Energy, Nevada Operations Office in support of the Nevada Environmental Restoration Project at the Nevada Test Site, Nye County, Nevada. The well was originally drilled to a total depth of 725.4 meters in 1965 for use as a hydrologic test hole in the northern portion of Yucca Flat in Area 8 of the Nevada Test Site. The well is located up-gradient of the Yucca Flat underground test area and penetrates deep into the Paleozoic rocks that form the lower carbonate aquifer of the NTS and surrounding areas. The original 24.4-centimeter-diameter borehole was drilled to a depth of 725.4 meters and left uncompleted. Water-level measurements were made periodically by the U.S. Geological Survey, but access to the water table was lost between 1979 and 1981 due to hole sloughing. In 1993, the hole was opened to 44.5 centimeters and cased off to a depth of 670.0 meters. The hole diameter was then decreased to 31.1 centimeters for drilling to a total depth of 796.4 meters. The depth to water in the open borehole was measured at 658.7 meters on March 18, 1993.
\end{abstract}

One completion string with six external packers and three screened intervals (with sliding sleeves), connected via a wye to a pumping riser, was installed in the well. The TAM ${ }^{\text {TM }}$ Combination Tool was used to inflate the packers and to emplace cement between screened intervals. This first-time use of the TAM ${ }^{\mathrm{TM}}$ process at the Nevada Test Site was only partially successful, though the well was successfully recompleted and now provides access to three completion zones in the lower carbonate aquifer for future testing.

Detailed stratigraphic and lithologic logs are included in the report. The well penetrated Quaternary/Tertiary-age alluvium deposited on Tertiary-age bedded and partially welded ashflow tuffs of the Volcanics of Big Dome and the Volcanics of Oak Spring Butte. The basal Tertiary unit overlies Cambrian-age dolomite and shale of the Nopah Formation, which appears conformably to overlie carbonate rocks of the Bonanza King Formation. The lowest 150 meters of the borehole penetrated dolomite of the Banded Mountain Member. This unit is part of the lower carbonate aquifer and is the main water-producing unit in the well. 
This page intentionally left blank. 


\section{Table of Contents}

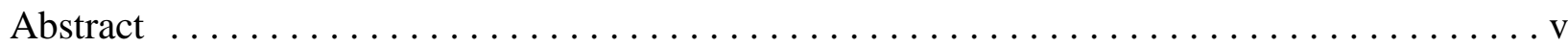

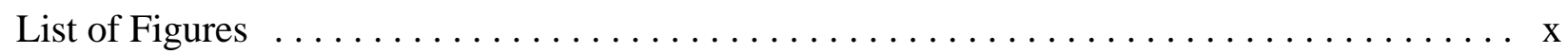

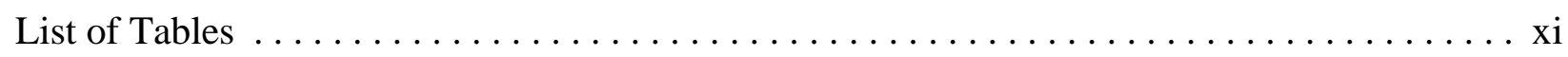

List of Acronyms and Abbreviations $\ldots \ldots \ldots \ldots \ldots \ldots \ldots \ldots \ldots \ldots \ldots \ldots \ldots$

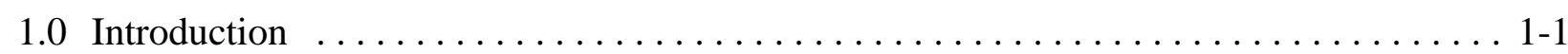

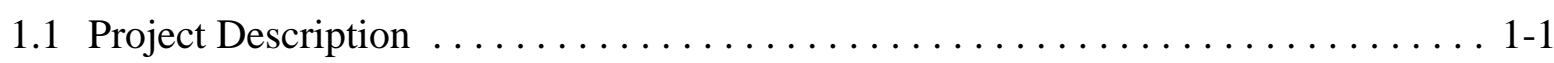

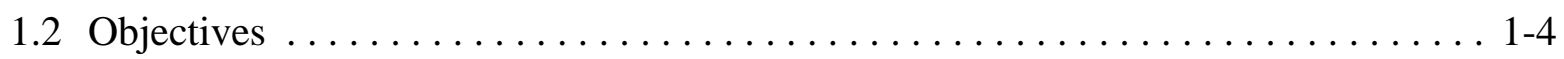

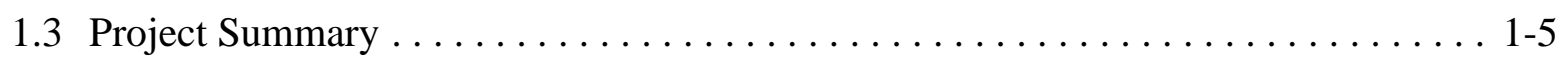

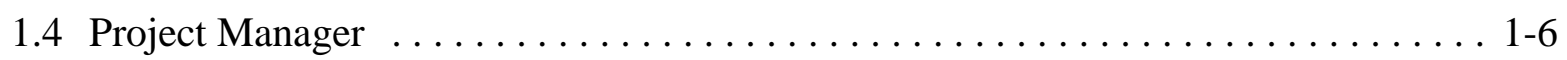

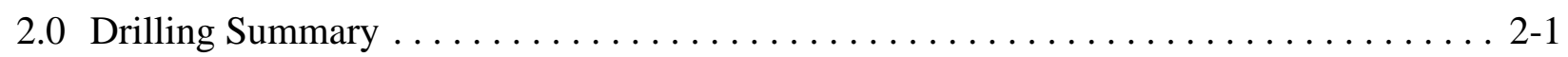

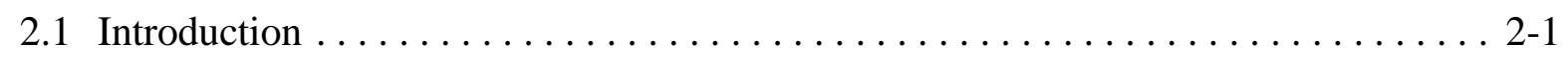

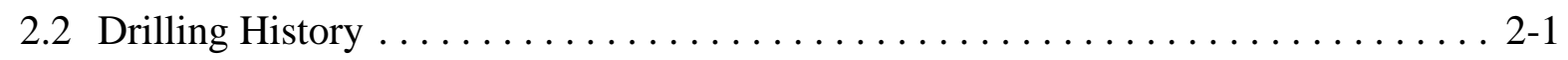

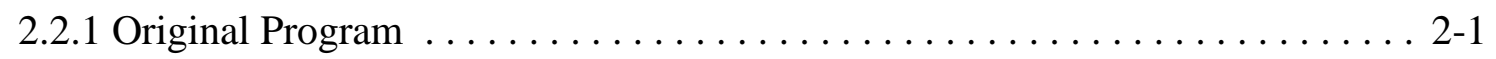

2.2.2 Recompletion Drilling . . . . . . . . . . . . . . . .

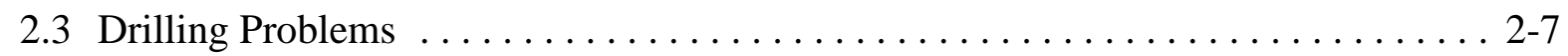

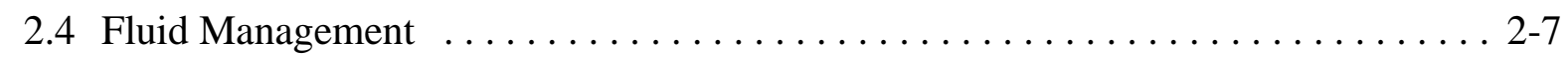

3.0 Geologic Data Collection $\ldots \ldots \ldots \ldots \ldots \ldots \ldots \ldots \ldots \ldots \ldots \ldots \ldots \ldots \ldots \ldots \ldots \ldots \ldots \ldots$

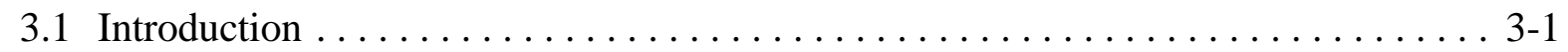

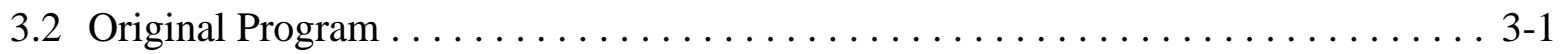

3.3 Collection of Drill Cuttings during Deepening of Well UE-10j . . . . . . . . 3-1

3.4 Sidewall Core Samples . . . . . . . . . . . . . . . . . . . . . . . . 3-1

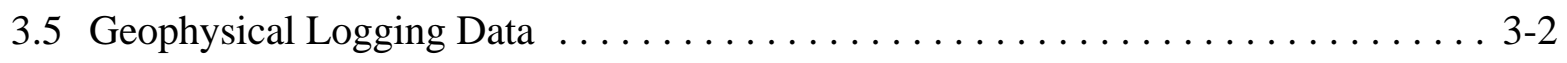

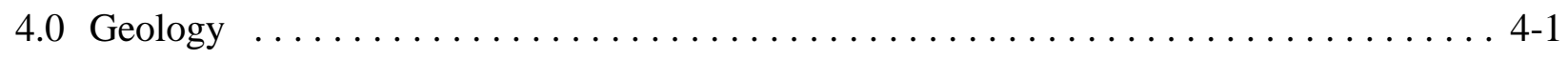




\section{Table of Contents (Continued)}

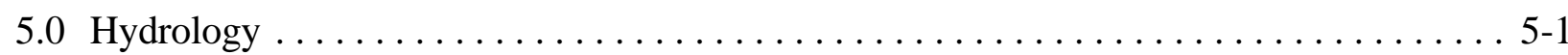

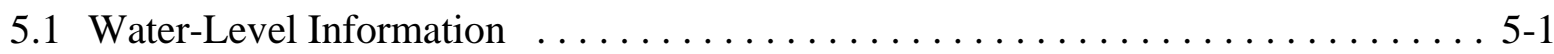

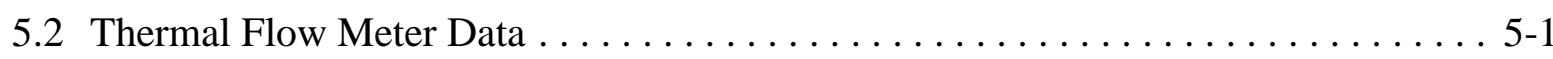

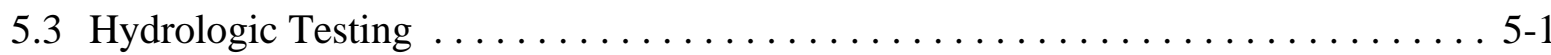

6.0 Precompletion and Open-Hole Development ...................... 6-1

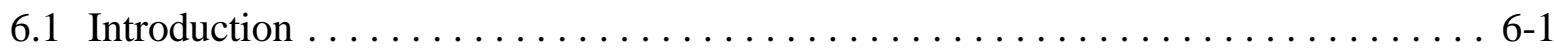

6.2 Well-Development Methods .......................... 6-1

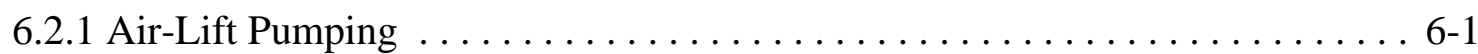

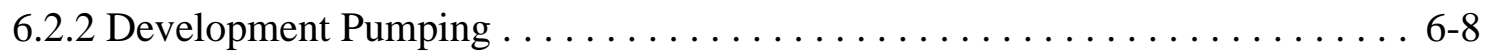

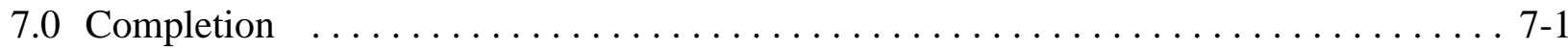

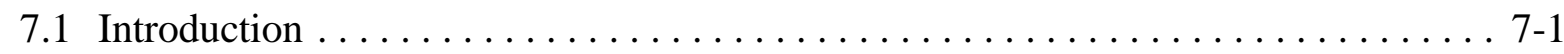

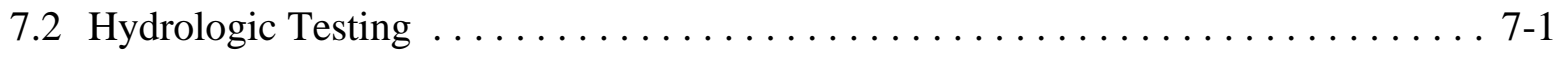

7.3 Well Completion Design .......................... $7-5$

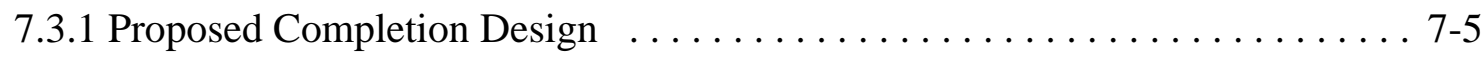

7.3.2 Actual Completion Design ........................ 7-5

7.3.3 Rationale for Differences between Actual and Proposed Well Design ..... . . 7-9

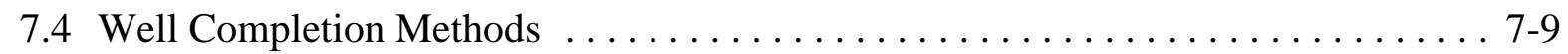

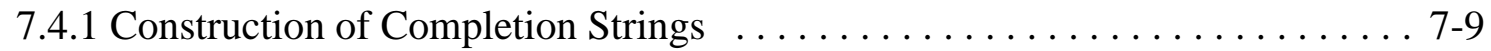

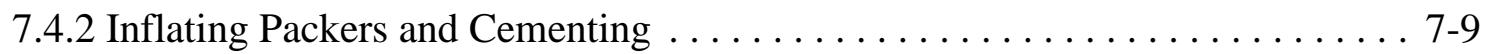

7.4.3 Discussion ..................................... 7-11

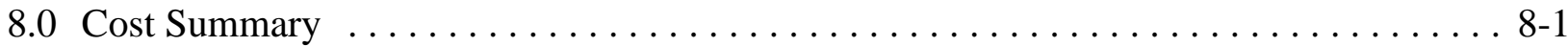

9.0 Summary, Recommendations, and Lessons Learned $\ldots \ldots \ldots \ldots \ldots \ldots \ldots$. $9-1$

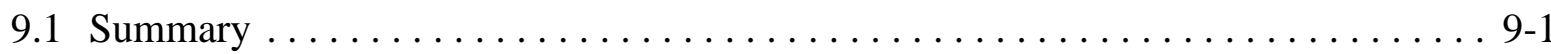

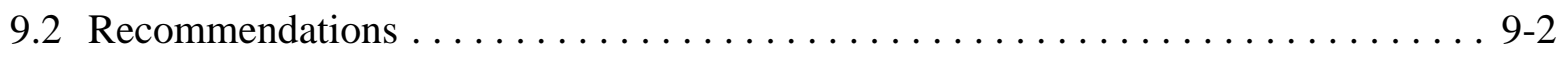

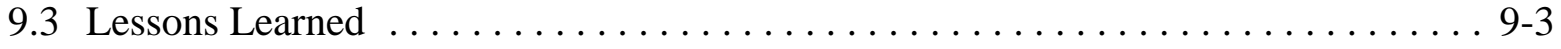

9.3.1 Drilling and Development Procedures . . . . . . . . . . . . . . . . . 9-3

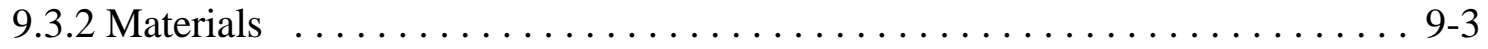

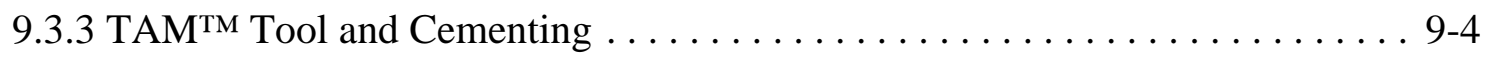

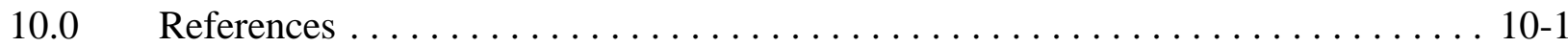




\section{Table of Contents (Continued)}

Appendix A Drilling Data

A-1 List of Records of Verbal Communication for Well UE-10j

A-2 Drilling Parameter Logs for Well UE-10j

A-3 Casing and Tubing Data for Well UE-10j

A-4 Well UE-10j Drilling Fluids, Additives, and Cement Composition

Appendix B-F - Fluid Management Data

Appendix C-Stratigraphic and Lithologic Logs

Appendix D- Geophysical Logs

Distribution List 


\section{List of Figures}

Number

Title

Page

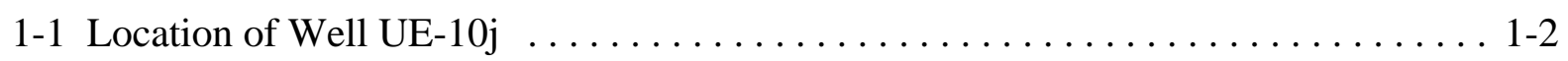

1-2 Map Showing Drill Holes and Surface Features in the Vicinity of

Well UE-10j ....................................... 1-3

2-1 Well UE-10j Recompletion History $\ldots \ldots \ldots \ldots \ldots \ldots \ldots \ldots \ldots \ldots \ldots \ldots \ldots \ldots \ldots$

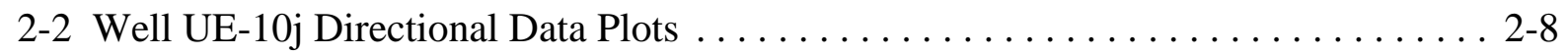

4-1 Predicted and Actual Stratigraphy of Well UE-10j $\ldots \ldots \ldots \ldots \ldots \ldots \ldots \ldots$ 4-3

6-1 Well UE-10j Recompletion Hydrologic Testing History $\ldots \ldots \ldots \ldots \ldots \ldots \ldots$ 6-3

6-2 Schematic for Well UE-10j Showing Washout Zones Selected

for Development . ................................. 6-5

6-3 Diagram of Dipstick (Air-Lift) Method of Development with Caliper Log for Well UE-10j ................................. 6-7

7-1 As-Built Schematic of Well UE-10j Completion String $\ldots \ldots \ldots \ldots \ldots \ldots \ldots$ 7-2

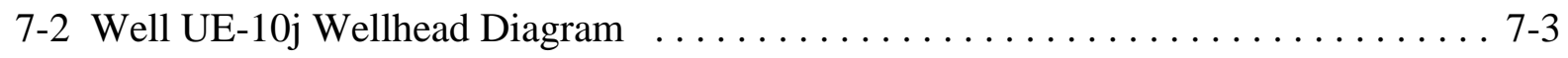

7-3 Construction Detail of Completion String of Well UE-10j $\ldots \ldots \ldots \ldots \ldots \ldots$ 7-7

$7-4$ Simplified Drawing of $\mathrm{TAM}^{\mathrm{TM}}$ Combination Tool $\ldots \ldots \ldots \ldots \ldots \ldots \ldots \ldots \ldots \ldots \ldots \ldots$

8-1 Planned versus Actual Costs for Drilling and Developing Well UE-10j ....... 8-2

8-2 Planned versus Actual Costs for Recompletion of Well UE-10j $\ldots \ldots \ldots \ldots \ldots$ 8-3 


\section{List of Tables}

Number

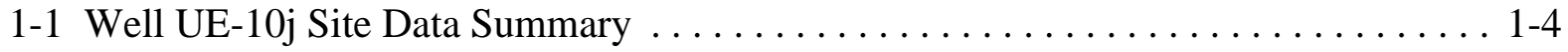

2-1 Abridged Drill Hole Statistics for Well UE-10j .................... 2-5

3-1 Well UE-10j Summary of Sidewall Core Samples .................. 3-2

3-2 Well UE-10j Geophysical Log Summary . . . . . . . . . . . . . . . . 3-4

7-1 Well UE-10j Drill-Stem (Straddle Packer) Test Results $\ldots \ldots \ldots \ldots \ldots \ldots \ldots$ 7-4

7-2 Well UE-10j Construction Material Summary $\ldots \ldots \ldots \ldots \ldots \ldots \ldots \ldots \ldots \ldots \ldots$

8-1 Well UE-10j Projected versus Actual Costs $\ldots \ldots \ldots \ldots \ldots \ldots \ldots \ldots \ldots$ 8-1

C-1 Drilling and Recovery Data for Ten Cores Cut in Well UE-10j in 1965 . . . . . . . C-6

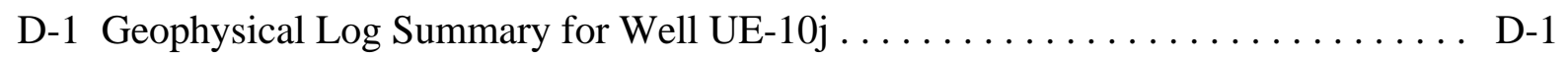

D-2 Summary of Geophysical Logs Run in Well UE-10j, 1965 to 1983 .......... D-2 


\section{List of Acronyms and Abbreviations}

$\begin{array}{ll}\text { cm } & \text { centimeter } \\ \text { DOE } & \text { U.S. Department of Energy } \\ \mathrm{E} & \text { East } \\ \mathrm{ft} & \text { foot } \\ \text { gal } & \text { gallon } \\ \text { gpm } & \text { gallon per minute } \\ \text { in. } & \text { inch } \\ \text { IT } & \text { IT Corporation } \\ \text { LLNL } & \text { Lawrence Livermore National Laboratory } \\ \mathrm{m} & \text { meter } \\ \mathrm{m}^{3} & \text { cubic meter } \\ \mathrm{m}^{3} / \mathrm{min} & \text { cubic meter per minute } \\ \text { MPa } & \text { megapascals } \\ \mathrm{N} & \text { North } \\ \mathrm{NTS} & \text { Nevada Test Site } \\ \text { od } & \text { outside diameter } \\ \text { PAIL } & \text { photon annulus investigation log } \\ \text { psi } & \text { pounds per square inch } \\ \text { RSN } & \text { Raytheon Services Nevada } \\ \text { TD } & \text { total depth } \\ \text { TFM } & \text { thermal flow meter } \\ \text { UGTA } & \text { Underground Test Area } \\ \text { USGS } & \text { U.S. Geological Survey } \\ & \end{array}$




\subsection{Introduction}

\subsection{Project Description}

The Well UE-10j recompletion project was conducted for the U.S. Department of Energy (DOE), Nevada Operations Office, in support of the Nevada Environmental Restoration Project at the Nevada Test Site (NTS), Nye County, Nevada. The Well UE-10j recompletion project is part of the DOE's Underground Test Area (UGTA) project at the NTS. The goals of the UGTA project include evaluating the nature and extent of contamination in groundwater due to underground nuclear testing, and establishing a long-term groundwater monitoring network. As part of the UGTA project, scientists are developing computer models to predict groundwater flow and contaminant migration within and near the NTS. To develop and test these models it is necessary to collect geologic, geophysical, and hydrologic data from new and existing wells to define groundwater pathways, migration rates, and quality. Another major objective of the Well UE-10j project was to introduce the use of innovative well-cementing and completion techniques not typically used at the NTS. The well will become part of the UGTA monitoring well network.

Well UE-10j is located in northern Yucca Flat in Area 8 of the NTS (Figure 1-1) The well was originally drilled in 1965 as a hydrologic test hole. Static water-level data were obtained regularly from the well, but sometime between 1979 and 1981, access to the water table was lost due to hole sloughing or bridging above the water table.

Well UE-10j was selected for recompletion for two main reasons: 1) it is located up-gradient of the Yucca Flat underground test area, and 2) it penetrates deep into the Paleozoic rocks that form the lower carbonate aquifer of the NTS and surrounding areas (Winograd and Thordarson, 1975). The closest underground nuclear test to the UE-10j site is located approximately 469 meters (m) (1,539 feet [ft]) southwest of the well. Figure 1-2 shows the locations of drill holes and surface features near Well UE-10j.

The Nevada State Planar Coordinates of the well collar are North (N) 887,035.1 and East (E) 670,453.4ft; the Universal Transverse Mercator coordinates are N 4,115,545.2, E 581,526.6 m. The ground surface elevation at the wellhead is $1,394.0 \mathrm{~m}(4,573.4 \mathrm{ft})$. Additional site summary and survey information is provided in Table 1-1. 


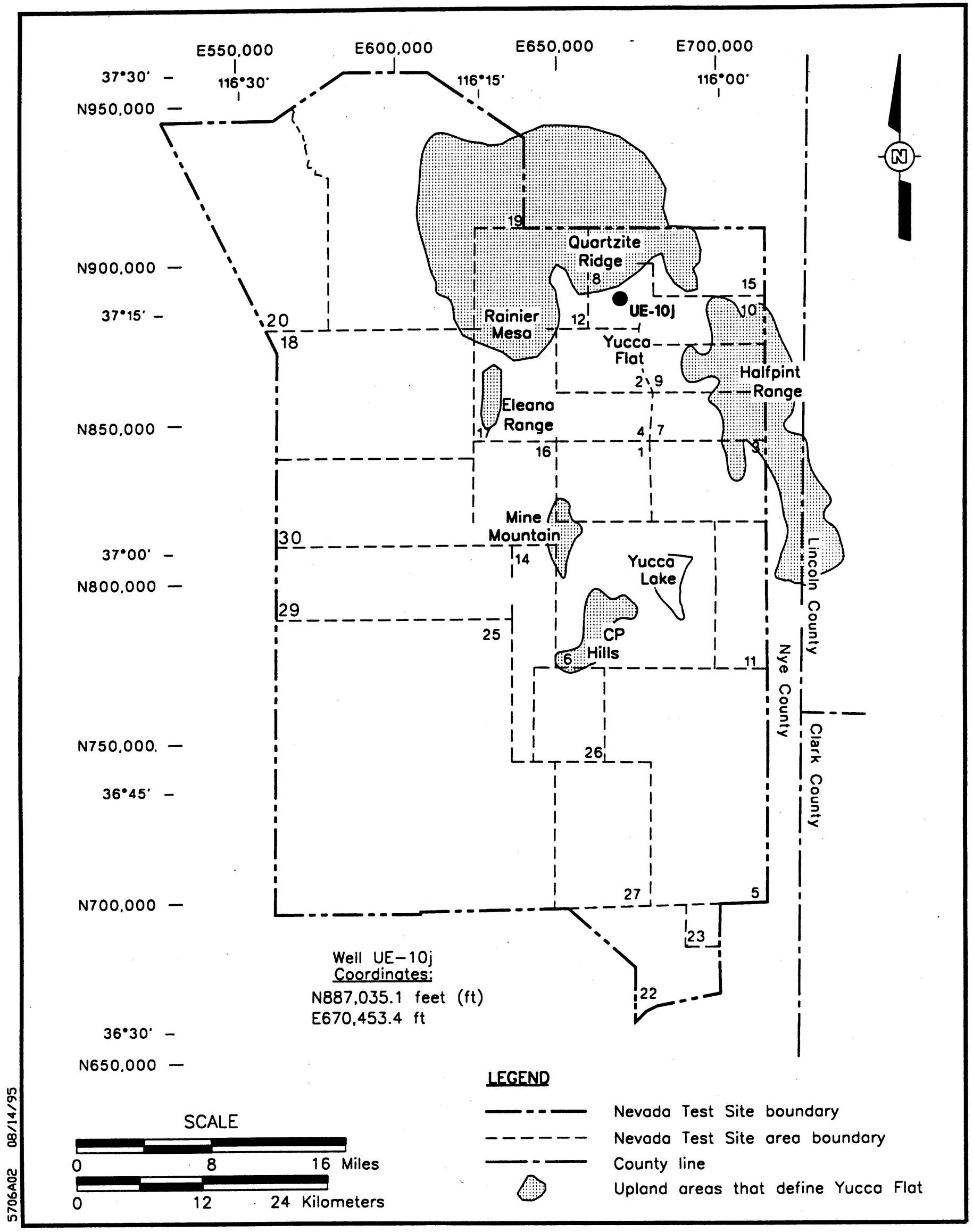

Figure 1-1

Location of Well UE-10j 


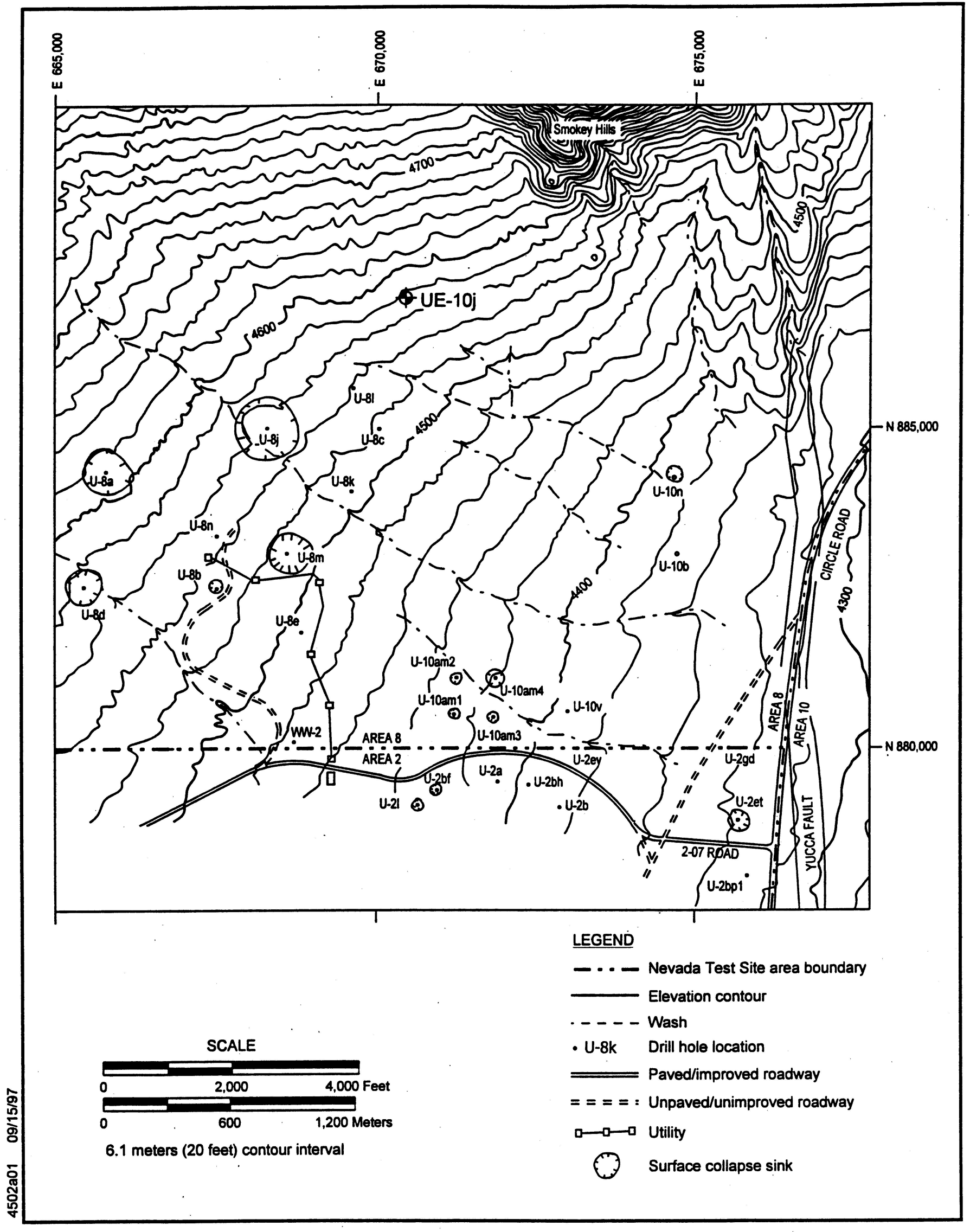

Figure 1-2

Map Showing Drill Holes and Surface Features in the Vicinity of Well UE-10j 


\section{Table 1-1 \\ Well UE-10j Site Data Summary}

\begin{tabular}{|c|c|c|}
\hline \multicolumn{2}{|c|}{ Hole Designation } & UE-10j \\
\hline \multicolumn{2}{|c|}{ Site Coordinates ${ }^{a}$} & $\begin{array}{c}\text { Central Nevada State Planar: } \\
\text { N 887,035.1, E 670,453.4 feet }(\mathrm{ft}) \\
\text { Universal Transverse Mercator (Zone 11): } \\
\text { N 4,115,545.2, E 581,526.6 meters (m) }\end{array}$ \\
\hline \multicolumn{2}{|c|}{ Surface Elevation ${ }^{b}$} & $1,394.0 \mathrm{~m}(4,573.4 \mathrm{ft})$ \\
\hline \multirow{2}{*}{ Drilled Depth } & Original (1965) & $725.4 \mathrm{~m}(2,380 \mathrm{ft})$ \\
\hline & Recompletion (1993) & $796.4 \mathrm{~m}(2,613 \mathrm{ft})$ \\
\hline \multicolumn{2}{|c|}{ Fluid-Level Depth (open borehole) } & $658.7 \mathrm{~m}(2,161 \mathrm{ft})$ \\
\hline \multicolumn{2}{|c|}{ Fluid-Level Elevation (open borehole) } & $735.3 \mathrm{~m}(2,412 \mathrm{ft})$ \\
\hline
\end{tabular}

a 1927 North American Datum. Measurement made by RSN Survey.

b 1929 North American Vertical Datum. Measurement made by RSN Survey.

IT Corporation (IT) was the principal environmental contractor for the project. The roles and responsibilities of IT and other contractors involved in the project are described in the Raytheon Services Nevada (RSN) Drilling and Completion Programs (RSN, 1992; 1993a).

This document presents construction data and summarizes scientific data gathered during the recompletion drilling and well-installation phases of the investigation. The drilling history, geotechnical data collection, and well-installation design are summarized herein, and the lithologic log is provided in final form. Information on precompletion development can be found in the Precompletion Hydrologic Testing Documentation Package for Well UE-10j (IT, 1995). Additional information on water levels, aquifer testing, and groundwater sampling will be provided after any well testing is done. Additional data on results of any geologic and geophysical investigations will be presented in one or more analysis and interpretation reports.

\subsection{Objectives}

The primary purpose of recompleting Well UE-10j was to provide additional hydrologic and stratigraphic data for the lower carbonate aquifer. Individual objectives, as discussed in Recompletion Criteria for Well UE-10j (IT, 1992), include the following:

- Obtain water-level data to evaluate the magnitude of vertical gradients.

- Obtain subsurface stratigraphic and structural geology data.

- Obtain geophysical and geologic data to evaluate the rock hydraulic properties. 
- Obtain hydrologic data from testing to evaluate the in-situ rock hydraulic properties.

- Obtain water-chemistry data to determine local groundwater chemistry.

- Evaluate well-cementing and completion techniques not traditionally used at the NTS.

\subsection{Project Summary}

Well UE-10j was drilled in 1965 as an exploratory hole to obtain geologic and hydrologic data. The 24.4-centimeter (cm) (9e -inch [in.]) hole was drilled (from under a 20-in. surface conductor

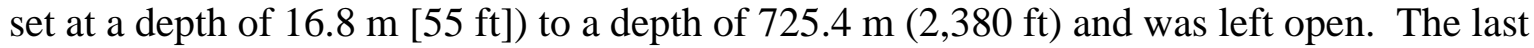
measurement made in the hole before access to the water table was lost due to hole sloughing indicated a static water level at a depth of $657.8 \mathrm{~m}(2,158 \mathrm{ft})$ in 1976 . Several geophysical $\operatorname{logs}$ were run in the hole between 1965 and 1983.

Recompletion activities began in January 1993 when Well UE-10j was reamed to $670.6 \mathrm{~m}$

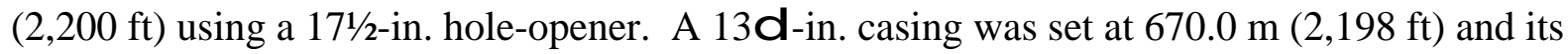
annulus was cemented to the surface. Cement was emplaced inside the casing to a depth of $580.3 \mathrm{~m}(1,904 \mathrm{ft})$, and drilling continued through the cement with a 121/4-in. bit to the total depth (TD) of the hole at $796.4 \mathrm{~m}$ (2,613 ft). Recompletion drilling at Well UE-10j was conducted using direct circulation; Davis Mix was used above the water table and air-foam was used below

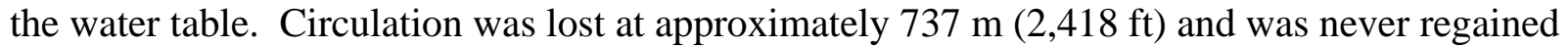
despite all efforts. Several wash-out zones were encountered during recompletion drilling, and drilling was finally halted because of increasing difficulty in keeping the hole free of fill. The hole was left with $22.6 \mathrm{~m}$ (74 ft) of fill, resulting in a working depth in the well of $773.9 \mathrm{~m}$ $(2,539 \mathrm{ft})$.

No drill cuttings were collected from Well UE-10j because of lost circulation. However, rotary sidewall core samples were collected at 13 locations. Geophysical logs were run periodically during drilling to aid in drilling and construction of the well and after drilling was completed to aid in verification of the geology and the hydrologic characteristics of the rocks. Recompletion drilling penetrated only Paleozoic-age carbonate rocks.

Precompletion open-hole development was conducted immediately after the conclusion of drilling. The fluid level in the borehole was $658.7 \mathrm{~m}(2,161 \mathrm{ft})$, as measured in the open borehole in March 1993. Operations at Well UE-10j were suspended for five months, and then completion activities began in October 1993 with well-purging, oxygen-activation flow logging, and drill-stem testing. The results of these tests were used to select zones for screening, and on November 3, 1993, installation of two connected completion strings was begun. A 51/2-in. 
outside-diameter (od) casing containing six external packers and three screened intervals (with sliding sleeves) was landed near the bottom of the hole at $773.0 \mathrm{~m}(2,536.1 \mathrm{ft})$. This string was connected to a pumping riser made of $4 \frac{1}{2} 2$-in. od casing. The completion assembly was positioned such that the crossover wye connecting the two strings is located at the depth of

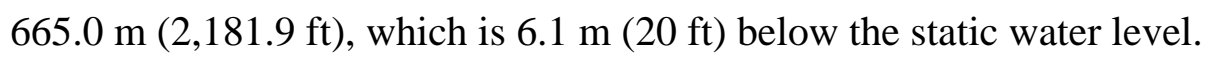

Screened intervals that provide access to three completion zones are located at the following depths: \#1) 765.0 to $773.0 \mathrm{~m}$ (2,510.0 to 2,536.1 ft); \#2) 732.3 to $740.1 \mathrm{~m}(2,402.5$ to 2,428.3 ft); and \#3) 691.1 to $699.0 \mathrm{~m}$ (2,267.4 to 2,293.2 ft). Six rubber packers are located in the string, one above and one below each sliding sleeve to isolate the three completion zones. The packers were inflated with water using the $\mathrm{TAM}^{\mathrm{TM}}$ Combination Tool, and two packer intervals were selected for cementing. The interval 704.4 to $718.4 \mathrm{~m}$ (2,311 to 2,357 ft), planned to separate completion zones \#2 and \#3, was successfully cemented using the $\mathrm{TAM}^{\mathrm{TM}}$ tool, but the procedure was unsuccessful in the second cement interval, above the uppermost packer. Thus, only one packer is present above zone \#3 to serve as a hydraulic barrier. Completion zones \#1 and \#2 are separated by three packers.

Because drilling of Well UE-10-j was stopped $117.7 \mathrm{~m}$ (386 ft) shallower than the planned depth of $914.4 \mathrm{~m}(3,000 \mathrm{ft})$, and because no cuttings were collected, less geologic data than desired was obtained from the hole. However, the innovative completion methods planned for testing on this well were successfully implemented, though a few problems were encountered with the TAM $^{\mathrm{TM}}$ cementing process. Well UE-10j was successfully completed, providing access to the three planned completion zones in the lower carbonate aquifer for future testing.

\subsection{Project Manager}

Inquiries regarding the Well UE-10j recompletion project should be directed to the UGTA Project Manager:

Environmental Restoration Division U.S. Department of Energy, Nevada Operations Office Post Office Box 98518 Las Vegas, Nevada 89193-8518 


\subsection{Drilling Summary}

\subsection{Introduction}

Drilling requirements for the Well UE-10j recompletion were outlined in the RSN Drilling Program (RSN, 1992) and changes to the program were documented in RSN Records of Verbal Communication (Appendix A-1). The following summary was compiled from the RSN daily rig reports, field notes prepared by the IT Field Representative, and from the Fenix \& Scisson Well UE-10j hole history (F\&S, 1965, with Additional Work sheets), where complete details of drilling activities can be found. Figure 2-1 is a chart of the recompletion drilling and construction history for Well UE-10j. A summary of drilling statistics for Well UE-10j can be found in Table 2-1.

\subsection{Drilling History}

\subsubsection{Original Program}

Well UE-10j was drilled as an exploratory hole in 1965 to obtain geologic and hydrologic information (Ege et al., 1965). After drilling of a 66-cm (26-in.) surface hole, Well UE-10j was drilled to a TD of $725.4 \mathrm{~m}(2,380 \mathrm{ft})$ using direct circulation and air-foam with a 9 e -in. bit. A

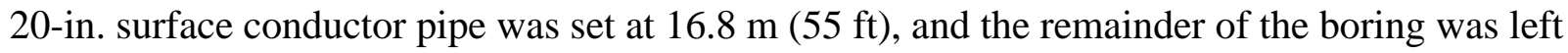
as an open hole. At the start of recompletion activities at Well UE-10j, it was known that the hole had a severe dog-leg between 450.8 and $517.9 \mathrm{~m}(1,479$ to $1,699 \mathrm{ft})$ and that a $9.2-\mathrm{cm}$ by 3.4-m (3e -in. by 11-ft) long geophone had been lost in the hole below approximately $694.9 \mathrm{~m}$ (2,280 ft) during a Vibroseis survey in 1976 (RSN, 1992). On June 24, 1976, the static water level was measured at a depth of $658 \mathrm{~m}(2,158 \mathrm{ft})$. Sometime between logging runs in the borehole conducted in May 1979 and September 1981, borehole sloughing or bridging had occurred such that the borehole was inaccessible below approximately $442.0 \mathrm{~m}(1,450 \mathrm{ft})$. Thus, no additional water-level measurements were possible. The last recorded measurement of the hole depth was $434.6 \mathrm{~m}$ (1,426 ft) on August 4, 1992 (RSN, 1992).

\subsubsection{Recompletion Drilling}

Drilling operations began on January 29, 1993, when the Reynolds Electrical \& Engineering Company, Inc. crew began rigging up a Cardwell 500 (Class II) drill rig. The drill pad had been previously prepared, and a lined sump (another was added during drilling) and an infiltration basin had been constructed. The rat and mouse holes were redrilled, and the bottom of the hole was initially tagged at $435.9 \mathrm{~m}(1,430 \mathrm{ft})$. 
This page intentionally left blank. 


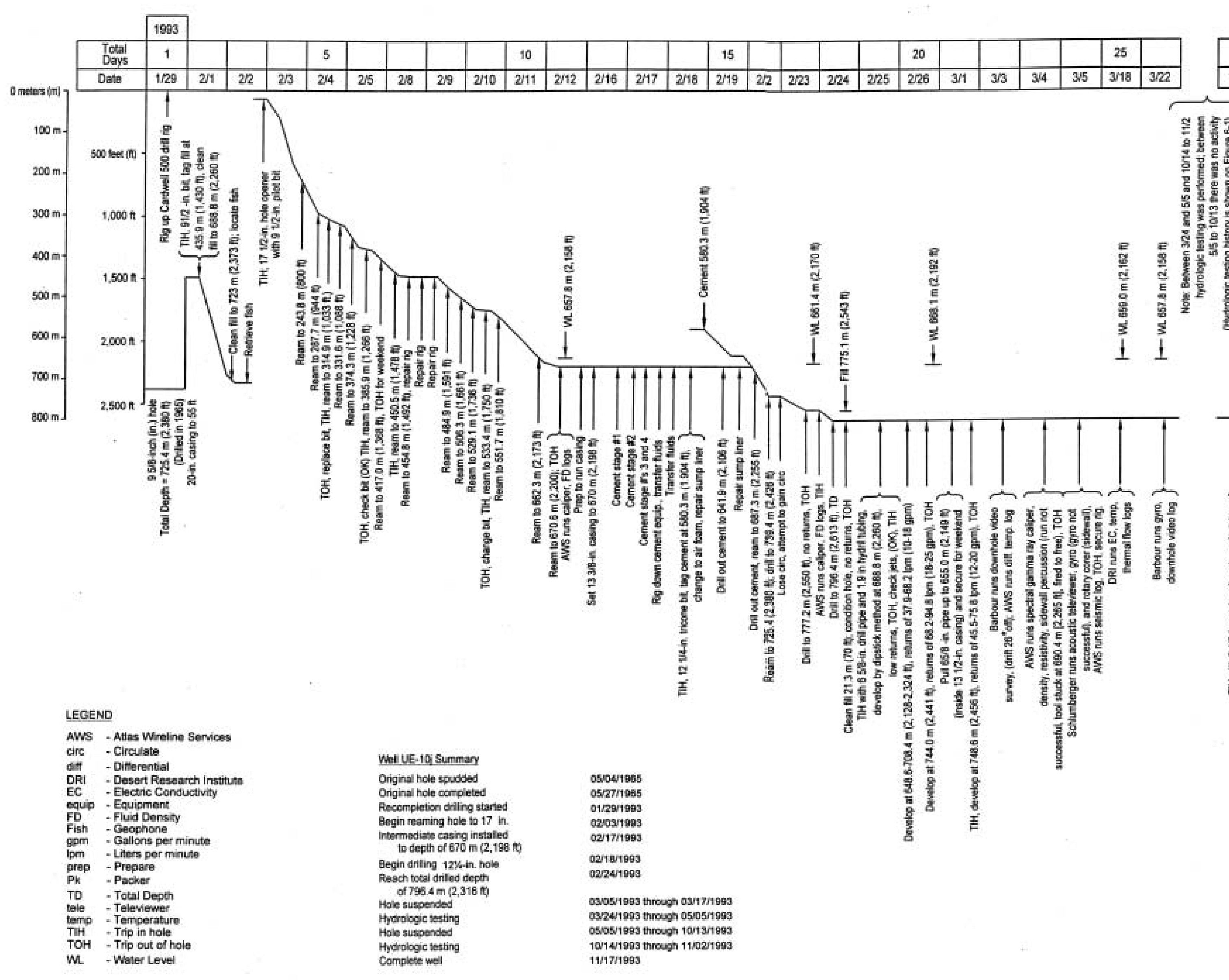

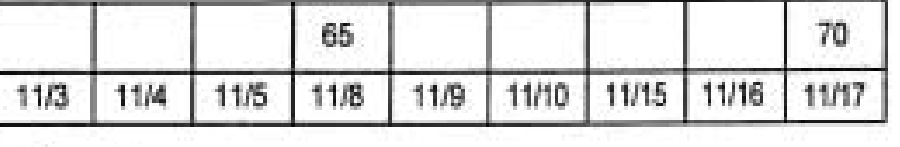
If 政 政 要㶽 娄

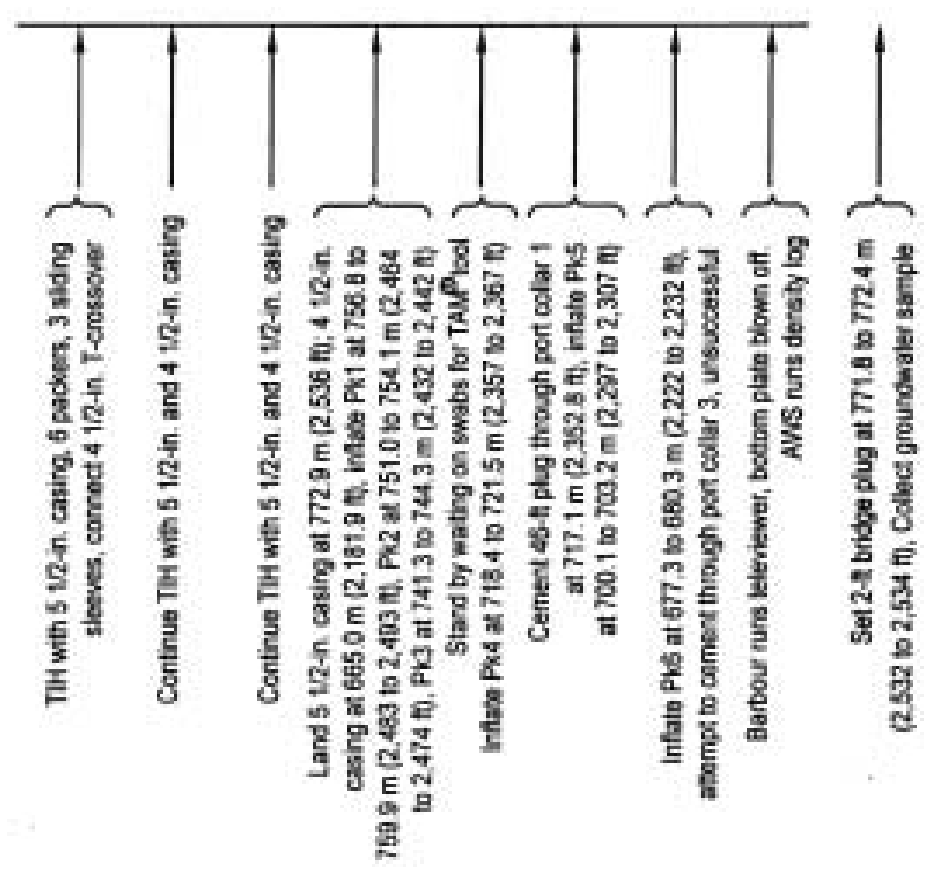

el UE-10; Summ: Hydrologe sesting
Complete wel 
This page intentionally left blank. 
Table 2-1

Abridged Drill Hole Statistics for Well UE-10j

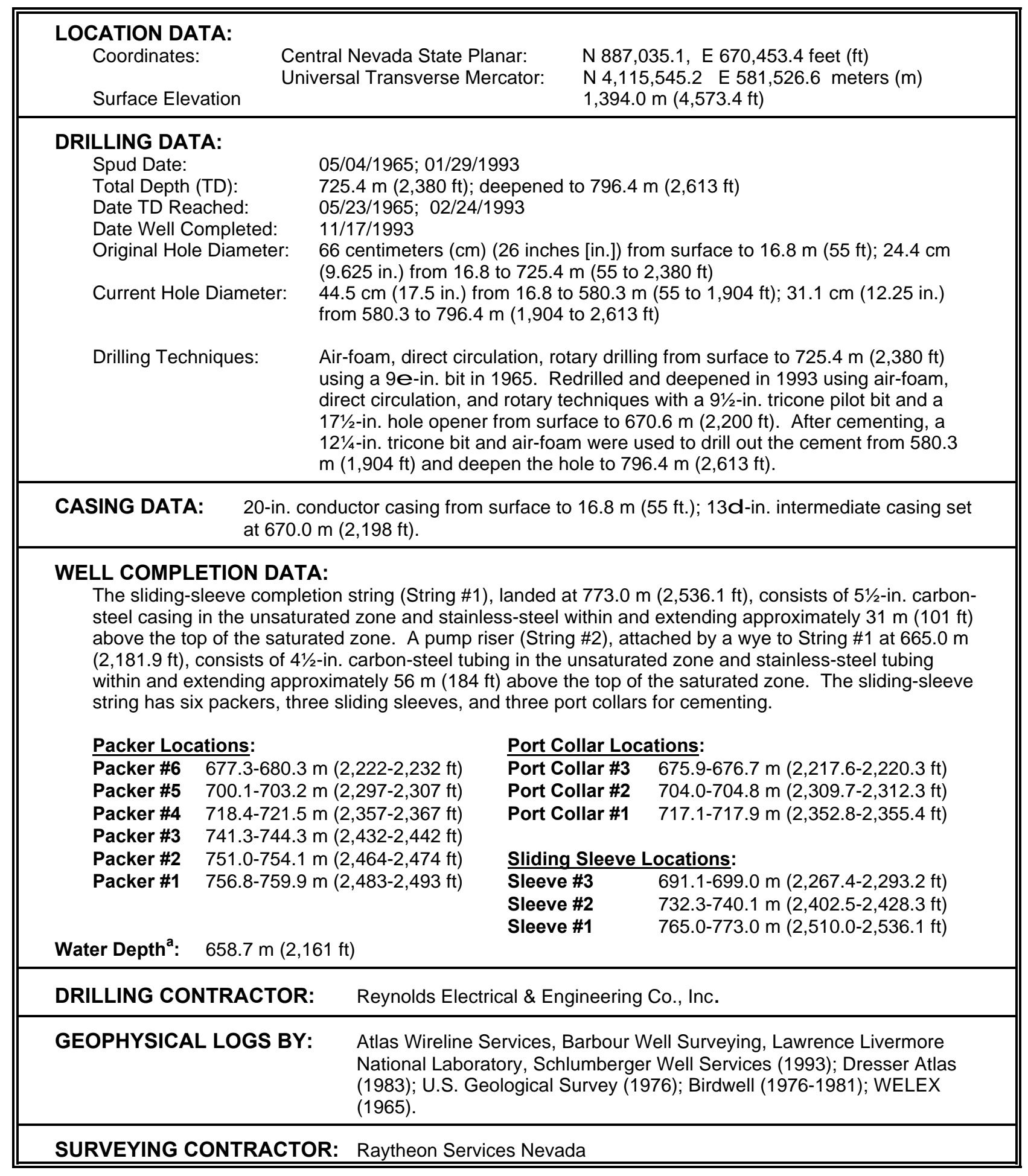

a Fluid level in the open borehole as of March 18, 1993. 
The fill was cleaned out on February 1 and 2, 1993, to $723.3 \mathrm{~m}$ (2,373 ft) using a 91/2-in. tricone bit and a bentonite air-foam drilling fluid (Davis Mix; Appendix A-4), The geophone (the "fish") lost in 1976 was tagged at $723.3 \mathrm{~m}(2,373 \mathrm{ft})$, and the string was tripped out of the hole to replace the bit with a fishing tool. The fishing tool, a $6 f$-in. conventional core barrel equipped with an $8 \frac{1}{2}$-in. cutter bit, was tripped into the hole and washed over the geophone. When the assembly was tripped out, the geophone was recovered.

The drill stem was next retooled with a 171/2-in. hole opener and 91/2-in. tricone pilot bit. Reaming of the 24.4-cm (9e -in.) hole was initiated on February 3, 1993, and continued until

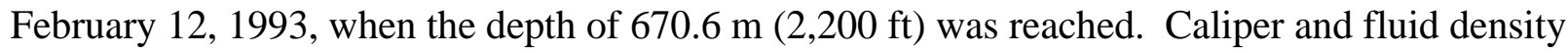
$\operatorname{logs}$ were run and the fluid level was measured at $657.8 \mathrm{~m}(2,158 \mathrm{ft})$. The drillers then installed 1.9-in. tubing for cementing an intermediate casing string. They next ran the $13 \mathrm{~d}$-in. intermediate casing, with a guide shoe and centralizer on the bottom joint, to a depth of $670.0 \mathrm{~m}$ $(2,198 \mathrm{ft})$. Cement was emplaced in one stage through the casing, by using a wiper plug and water to displace the cement, and then bumping the wiper plug with compressed air to 3.4 megapascals (MPa) (500 pounds per square inch [psi]) to shut in the casing and force the cement up the annulus, forming a bottom plug. The rest of the annulus was then cemented to the surface through the 1.9-in. tubing in three more stages on February 17 and 18, 1993. The top of cement inside the casing was tagged at $580.3 \mathrm{~m}(1,904 \mathrm{ft})$.

On February 18, 1993, drilling resumed through the cement in the casing with a 121/4-in. tricone bit and air-foam. After the cement was drilled out from inside the casing, reaming continued to

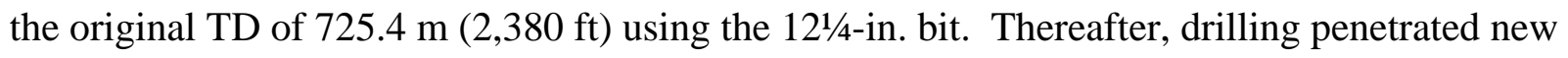
stratigraphy, and the collection of cuttings samples became an essential task. However, circulation was very poor, and only one poor-quality sample was taken, at $729.7 \mathrm{~m}(2,394 \mathrm{ft})$. Circulation was lost altogether at approximately $737.0 \mathrm{~m}$ (2,418 ft), and there were no more returns. For the remainder of the drilling operation, efforts to regain circulation, including the use of four compressors to increase air pressure, were not successful. No lost-circulation material was used in the hole.

Drilling was stopped for logging on February 23, 1993, at a depth of $777.2 \mathrm{~m}$ (2,550 ft). Caliper$\log$ data indicated three wash-out zones, at 763.8 to $766.3 \mathrm{~m}$ (2,506 to $2,514 \mathrm{ft}) ; 737.0$ to $739.4 \mathrm{~m}$ (2,418 to $2,426 \mathrm{ft})$; and 690.1 to $691.9 \mathrm{~m}$ (2,264 to $2,270 \mathrm{ft})$. 
Drilling resumed on February 24, 1993, and TD was reached at $796.4 \mathrm{~m} \mathrm{(2,613} \mathrm{ft)} \mathrm{later} \mathrm{that} \mathrm{day.}$ The decision to stop short of the planned 914.4-m (3,000-ft) depth was made because of increasing difficulty in keeping the hole free of fill. Hole bottom was tagged at $775.1 \mathrm{~m}$ $(2,543 \mathrm{ft})$, indicating about $21.3 \mathrm{~m}(70 \mathrm{ft})$ of fill had accumulated. There were no returns during the final drilling and clean-out. An additional $1.3 \mathrm{~m}(4 \mathrm{ft})$ of fill accumulated before the completion string was installed.

\subsection{Drilling Problems}

The two most serious problems encountered during reaming and deepening of Well UE-10j were loss of circulation and borehole sloughing. The lack of returns resulted in the loss of the geologic data typically available from samples of drill-cuttings. However, geologic data were later obtained from sidewall cores, geophysical logs, and a down-hole camera survey. The three wash-out zones encountered between 690.1 and $766.3 \mathrm{~m}$ (2,264 to 2,514 ft) were probably the main contributors to the fill. These zones are located in the carbonate portion of the hole and are probably related to fractures or solution features within the limestone.

Well UE-10j deviated severely from the vertical during original drilling. This deviation was not corrected during deepening of the hole in 1993, though reaming of the upper part of the hole probably eased the problem to some degree. The resulting dog-leg in the hole made later insertion of geophysical tools, casing, and tubing difficult. Vertical and plan view plots of the hole deviation are shown on Figure 2-2.

\section{$2.4 \quad$ Fluid Management}

A standard bentonite air-foam (Davis Mix) was used to drill the original (1965) hole; Davis Mix and air-foam were used to ream and deepen the hole in 1993. All fluids produced during the Well UE-10j deepening and completion were stored in lined sumps.

The drilling effluent was monitored in accordance with the methods prescribed in Recompletion Criteria for Well UE-10j (IT, 1992), Re-completion Plan for GCP UE-10j (RSN, 1992), and Fluid Management Plan for Saturated-Zone Operations at Well UE-10j (Rev. 3) (IT, 1993a). The results of analyses on samples of drilling fluid collected at Well UE-10j during drilling operations indicate that all fluid quality objectives were met. 


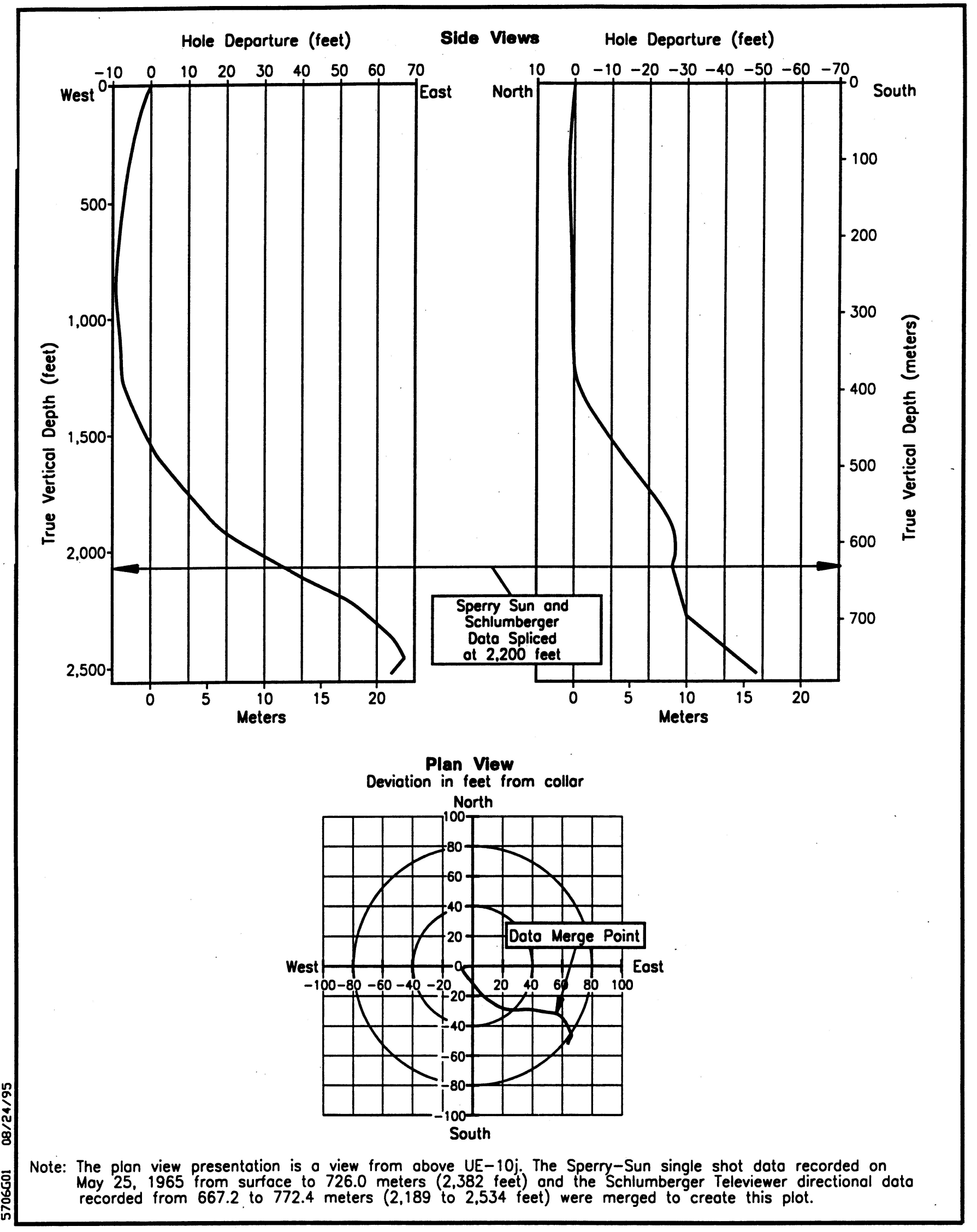

Figure 2-2

Well UE-10j Directional Data Plots 
Appendix B of this report contains the Well UE-10j Fluid Management Status report. The fluid disposition form lists final volumes and data for Stage $V$ well completion. The final volumes of fluids imported to and produced at Well UE-10j were calculated from vacuum-truck delivery tickets and fluid measurements in the lined sumps. The solids produced were calculated using the diameter of the borehole and the depth drilled (at UE-10j, appreciable solids were not produced below the water table). 
This page intentionally left blank. 


\subsection{Geologic Data Collection}

\subsection{Introduction}

This section describes the geologic data available from Well UE-10j and methods of data collection. Geologic data were already available for the upper $725.4 \mathrm{~m}(2,380 \mathrm{ft})$ of Well UE-10j, from the original drilling of the hole. Obtaining geologic data from the deepened portion of the hole was one of the primary objectives of Well UE-10j, to increase the understanding of the lower carbonate aquifer in this portion of the NTS.

\subsection{Original Program}

Exploratory hole UE-10j was originally drilled to a depth of $725.4 \mathrm{~m}(2,380 \mathrm{ft})$ by the Lawrence Radiation Laboratory (now Lawrence Livermore National Laboratory [LLNL]) in 1965. Nine 10.2-cm (4-in.) conventional cores $2.4 \mathrm{~m}(8 \mathrm{ft})$ long were taken between 113 and $657 \mathrm{~m}$ (370 to $2,158 \mathrm{ft})$ during drilling. Fifteen sidewall samples were obtained from $125 \mathrm{~m}(410 \mathrm{ft})$ to $168 \mathrm{~m}$ $(550 \mathrm{ft})$. Information for these samples is given in Appendix $\mathrm{C}$, and the conventional cores are stored in the U.S. Geological Survey (USGS) Core Library in Mercury, Nevada. A preliminary lithologic log was prepared by Ege et al. (1965).

\subsection{Collection of Drill Cuttings during Deepening of Well UE-10j}

The drilling program for the Well UE-10j recompletion called for collection of cuttings at 3.05-m $(10-\mathrm{ft})$ intervals below the depth of $725.4 \mathrm{~m}(2,380 \mathrm{ft})$. However, because of poor returns below $725.4 \mathrm{~m}$ (2,380 ft), drill cuttings were collected at only one depth interval (729.7 m [2,394 ft]). Circulation was lost completely below that depth, and no other samples were collected.

\subsection{Sidewall Core Samples}

A sidewall coring program was implemented as a means of obtaining lithologic data after failure to obtain cuttings samples. Coring locations were chosen based on the greatest chance for successful recovery and the widest range of lithological dissimilarities: caliper logs were examined to avoid washouts and fractures, and compensated density logs and the color video borehole survey provided information on rock densities, fractured areas, and color changes. From this information, 13 core sample locations were chosen between $681.2 \mathrm{~m}(2,235 \mathrm{ft})$ and TD.

After drilling was completed, Atlas Wireline Service attempted to collect percussion-gun sidewall cores but the tool became stuck, and was freed only by firing one of the barrels. 
Schlumberger Wireline Service then brought their rotary (mechanical) sidewall tool on site and obtained 13 samples on March 4, 1993.

The 2.54-cm (1-in.) diameter cores range in length from 1.9 to $4.8 \mathrm{~cm}$ (0.75 to $1.9 \mathrm{in}$.). Information for these samples is listed in Table 3-1. The core samples were collected and packaged by RSN, witnessed by IT, and then delivered by RSN to the USGS Core Library in Mercury, Nevada. The cores were collected, preserved, and transferred in accordance with applicable standard procedures.

Table 3-1

Well UE-10j Summary of Sidewall Core Samples

\begin{tabular}{|c|c|c|c|}
\hline $\begin{array}{c}\text { Core } \\
\text { Number }\end{array}$ & $\begin{array}{l}\text { Sample Depth } \\
\text { meters (feet) }\end{array}$ & $\begin{array}{l}\text { Sample Recovery } \\
\text { centimeters (inches) }\end{array}$ & Sample Description $^{\mathrm{b}}$ \\
\hline 1 & $762.0(2,500)$ & $3.8(1.5)$ & $\begin{array}{c}3.2 \text { centimeters }(\mathrm{cm})(1.25 \text { inches [in.]) solid, } \\
0.6 \mathrm{~cm}(0.25 \text { in.) in fragments }\end{array}$ \\
\hline 2 & $759.0(2,490)$ & $2.5(1.0)$ & All fragments \\
\hline 3 & $758.0(2,487)$ & $4.8(1.9)$ & One piece \\
\hline 4 & $744.6(2,443)$ & $4.4(1.75)$ & Minor fragments \\
\hline 5 & $743.7(2,440)$ & $4.4(1.75)$ & $3.2 \mathrm{~cm}(1.25 \mathrm{in}$.$) solid, 1.3 \mathrm{~cm}(0.5 \mathrm{in}$.$) in fragments$ \\
\hline 6 & $742.8(2,437)$ & $4.6(1.8)$ & Two pieces \\
\hline 7 & $734.6(2,410)$ & $2.5(1.0)$ & Minor fragments \\
\hline 8 & $732.7(2,404)$ & $1.9(0.75)$ & All fragments \\
\hline 9 & $718.1(2,356)$ & $3.2(1.25)$ & One piece \\
\hline 10 & $713.8(2,342)$ & $3.8(1.5)$ & $3.2 \mathrm{~cm}$ (1.25 in.) solid, $0.6 \mathrm{~cm}$ (0.25 in.) in fragments \\
\hline 11 & $705.3(2,314)$ & $3.2(1.25)$ & Small and large fragments \\
\hline 12 & $694.3(2,278)$ & $3.8(1.5)$ & Small and large fragments \\
\hline 13 & $681.2(2,235)$ & $4.4(1.75)$ & $2.5 \mathrm{~cm}$ (1 in.) solid, $1.9 \mathrm{~cm}$ (0.75 in.) in fragments \\
\hline
\end{tabular}

Samples taken by Schlumberger Wireline Service using a slim-hole rotary sidewall corer.

a Depth below ground level. Measurements from logging truck odometer.

b All samples are dolomite from the Banded Mountain Member of the Bonanza King Formation.

\subsection{Geophysical Logging Data}

Geophysical logs were run at various stages of drilling and recompletion to characterize the lithology, structure, and hydrogeologic properties of the rocks. In addition, logs were run to check hole conditions, to determine fluid levels and the extent of caving, and to monitor the completion process. All geophysical logs run in Well UE-10j during recompletion are listed in 
Table 3-2. Geophysical logs run during the original drilling of Well UE-10j and prior to recompletion (1965 through 1983) are listed in Appendix D.

Logging operations were conducted in three phases. The first phase was conducted after drilling to $670.6 \mathrm{~m}(2,200 \mathrm{ft})$ and during the placement of the $13 \mathrm{~d}$-in. casing. The next phase, after reaching TD at $796.4 \mathrm{~m}(2,613 \mathrm{ft})$, included hydrologic testing logs. The final phase of logging took place just prior to well completion and during well construction activities.

Overall, the quality of the geophysical data was acceptable. Enlarged portions of the borehole caused a marked decrease in the data quality for those logging tools that required contact with the borehole. Preliminary geophysical data from the caliper, compensated density, compensated neutron, spectral gamma ray, and differential temperature logs are presented as a composite log in Appendix D.

All geophysical logs from Well UE-10j are available from Bechtel Nevada in Mercury, Nevada. Copies of the logs obtained during recompletion activities are also available in files maintained by IT in Las Vegas, Nevada. 
Table 3-2

Well UE-10j Geophysical Log Summary

(Page 1 of 2)

\begin{tabular}{|c|c|c|c|c|c|c|}
\hline Geophysical Logs & Log Purpose & $\begin{array}{l}\text { Logging } \\
\text { Service }\end{array}$ & $\begin{array}{l}\text { Date } \\
\text { Logged }\end{array}$ & Run Number & $\begin{array}{l}\text { Top of Logged } \\
\text { Interval a } \\
\text { meters (feet) }\end{array}$ & $\begin{array}{l}\text { Bottom of Logged } \\
\text { Interval } \\
\text { meters (feet) }\end{array}$ \\
\hline Borehole Seismic Analysis (Vibroseis) & Lithologic determination & AWS $^{b}$ & $03 / 05 / 93$ & SGG-1 & $27.4(90)$ & $770.5(2,528)$ \\
\hline Borehole Acoustic Televiewer with Gyro & $\begin{array}{l}\text { Directional survey to measure } \\
\text { borehole deviation }\end{array}$ & sWS $^{c}$ & 03/05/93 & BHTV-1 & $667.5(2,190)$ & $774.2(2,540)$ \\
\hline Caliper & $\begin{array}{l}\text { Determine hole conditions, } \\
\text { cement volumes }\end{array}$ & $\begin{array}{l}\text { AWS } \\
\text { AWS } \\
\text { AWS }\end{array}$ & $\begin{array}{l}02 / 12 / 93 \\
02 / 23 / 93 \\
10 / 27 / 93\end{array}$ & $\begin{array}{l}\text { CA6-4 } \\
\text { CA6-5 } \\
\text { CA6-6 }\end{array}$ & $\begin{aligned} 0 & (0) \\
654.1 & (2,146) \\
657.8 & (2,158)\end{aligned}$ & $\begin{array}{ll}607.2 & (1,992) \\
770.5 & (2,528) \\
772.4 & (2,534)\end{array}$ \\
\hline Cement Top Nuclear & Determine top of cement & $\begin{array}{l}\text { AWS } \\
\text { AWS }\end{array}$ & $\begin{array}{l}02 / 16 / 93 \\
02 / 17 / 93\end{array}$ & $\begin{array}{l}\text { CTN-1 } \\
\text { CTN-2 }\end{array}$ & $\begin{array}{c}0(0) \\
133.8(439)\end{array}$ & $\begin{array}{l}656.2(2,153) \\
574.2(1,884)\end{array}$ \\
\hline $\begin{array}{l}\text { Compensated Densilog/Compensated } \\
\text { Neutron/Gamma Ray }\end{array}$ & $\begin{array}{l}\text { Lithologic determination/water } \\
\text { content/stratigraphic correlation }\end{array}$ & AWS & 03/04/93 & $\begin{array}{c}\text { GR-4/ } \\
\text { CN-1/CDL-1 }\end{array}$ & $652.3(2,140)$ & $773.6(2,538)$ \\
\hline Differential Temperature & Groundwater temperature & $\begin{array}{l}\text { AWS } \\
\text { AWS } \\
\text { AWS } \\
\text { AWS }\end{array}$ & $\begin{array}{l}03 / 03 / 93 \\
04 / 14 / 93 \\
11 / 15 / 93 \\
11 / 16 / 93\end{array}$ & $\begin{array}{l}\text { TL-1 } \\
\text { TL-2 } \\
\text { TL-4 } \\
\text { TL-5 }\end{array}$ & $\begin{array}{ll}630.9 & (2,070) \\
641.6 & (2,105) \\
667.5 & (2,190) \\
608.7 & (1,997)\end{array}$ & $\begin{array}{ll}738.8 & (2,424) \\
774.2 & (2,540) \\
731.5 & (2,400) \\
771.1 & (2,530)\end{array}$ \\
\hline Digital Spectralog & $\begin{array}{l}\text { Stratigraphic correlation, } \\
\text { mineralogy, natural radiation }\end{array}$ & AWS & 03/04/93 & SGR-2 & $660.8(2,168)$ & $773.6(2,538)$ \\
\hline $\begin{array}{l}\text { Downhole-Oriented Color Video (narrative } \\
\text { of video available from IT }{ }^{d} \text {, Las Vegas, } \\
\text { Nevada) }\end{array}$ & $\begin{array}{l}\text { Borehole examination for } \\
\text { fractures, lithology, and fluid flow }\end{array}$ & $\begin{array}{l}\text { BWS }^{e} \\
\text { BWS } \\
\text { BWS }\end{array}$ & $\begin{array}{l}03 / 03 / 93 \\
03 / 03 / 93 \\
03 / 22 / 93\end{array}$ & $\begin{array}{l}\text { TV-1 } \\
\text { TV-2 } \\
\text { TV-3 }\end{array}$ & $\begin{aligned} 0 & (0) \\
30.5 & (100) \\
0 & (0)\end{aligned}$ & $\begin{array}{ll}774.2 & (2,540) \\
774.2 & (2,540) \\
774.2 & (2,540)\end{array}$ \\
\hline Dual Laterolog/Gamma Ray & $\begin{array}{l}\text { Water saturation (sat. zone)/ } \\
\text { stratigraphic correlation }\end{array}$ & AWS & 03/04/93 & DLL-1/GR-3 & $664.5(2,180)$ & $771.4(2,531)$ \\
\hline
\end{tabular}


Table 3-2

Well UE-10j Geophysical Log Summary

(Page 2 of 2)

\begin{tabular}{|c|c|c|c|c|c|c|}
\hline Geophysical Logs & Log Purpose & $\begin{array}{l}\text { Logging } \\
\text { Service }\end{array}$ & $\begin{array}{l}\text { Date } \\
\text { Logged }\end{array}$ & Run Number & $\begin{array}{l}\text { Top of Logged } \\
\text { Interval a }^{\text {a }} \\
\text { meters (feet) }\end{array}$ & $\begin{array}{c}\text { Bottom of Logged } \\
\text { Interval } \\
\text { meters (feet) }\end{array}$ \\
\hline Fluid Density & Depth to fluid & $\begin{array}{l}\text { AWS } \\
\text { AWS } \\
\text { AWS } \\
\text { AWS } \\
\text { AWS } \\
\text { AWS }\end{array}$ & $\begin{array}{l}08 / 04 / 92 \\
02 / 12 / 93 \\
02 / 23 / 93 \\
11 / 10 / 93 \\
11 / 10 / 93 \\
11 / 10 / 93\end{array}$ & $\begin{array}{c}\text { DF-5 } \\
\text { DF-6 } \\
\text { DF-7 } \\
\text { DF-8 } \\
\text { DF-9 } \\
\text { DF-10 }\end{array}$ & $\begin{array}{cl}420.6 & (1,380) \\
651.4 & (2,137) \\
642.5 & (2,108) \\
12.8(42) \\
43.0(141) \\
637.6(2,092)\end{array}$ & $\begin{aligned} 434.3 & (1,425) \\
673.0 & (2,208) \\
674.5 & (2,213) \\
33.8 & (111) \\
65.2 & (214) \\
662.9 & (2,175)\end{aligned}$ \\
\hline Photon Annulus Investigation Log & $\begin{array}{l}\text { Omni-directional density (check } \\
\text { for cement and/or fluid location) }\end{array}$ & $\begin{array}{l}\text { AWS } \\
\text { AWS } \\
\text { AWS } \\
\text { AWS }\end{array}$ & $\begin{array}{l}11 / 08 / 93 \\
11 / 09 / 93 \\
11 / 10 / 93 \\
11 / 15 / 93\end{array}$ & $\begin{array}{c}\text { AIN-1 } \\
\text { AIN-2, } 3 \\
\text { AIN-4, } 5 \\
\text { AIN-6 }\end{array}$ & $\begin{array}{ll}638.9 & (2,096) \\
665.4 & (2,183) \\
645.6 & (2,118) \\
670.0 & (2,198)\end{array}$ & $\begin{array}{ll}764.7 & (2,509) \\
718.7 & (2,358) \\
716.0 & (2,349) \\
714.4 & (2,344)\end{array}$ \\
\hline Preliminary Collar Locator & Locate casing collar & $\begin{array}{l}\text { AWS } \\
\text { AWS }\end{array}$ & $\begin{array}{l}11 / 05 / 93 \\
11 / 17 / 93\end{array}$ & $\begin{array}{l}\text { CCL-1 } \\
\text { CCL-2 }\end{array}$ & $\begin{array}{ll}576.7 & (1,892) \\
670.6 & (2,200)\end{array}$ & $\begin{array}{ll}754.1 & (2,474) \\
769.3 & (2,525)\end{array}$ \\
\hline Sidewall Mechanical Coring Tool & $\begin{array}{l}\text { Geologic samples, geophysical } \\
\text { log correlation }\end{array}$ & SWS & 03/04/93 & MCT-1 & $681.2(2,235)$ & $762.0(2,500)$ \\
\hline Spinner/Temperature & $\begin{array}{l}\text { Determine fluid flow/ } \\
\text { temperatures under pumping } \\
\text { conditions }\end{array}$ & SWS & $10 / 26 / 93$ & $\begin{array}{l}\text { SPINR-1/ } \\
\text { TL-3 }\end{array}$ & $686.7(2,253)$ & $771.7(2,532)$ \\
\hline $\begin{array}{l}\text { Thermal Flow (Electrical Conductivity, } \\
\text { Temperature) }\end{array}$ & $\begin{array}{l}\text { Determine rate/direction of } \\
\text { groundwater flow within the } \\
\text { borehole }\end{array}$ & $\mathrm{DRI}^{\dagger}$ & 03/18/93 & 2 & $659.9(2,165)$ & $767.5(2,518)$ \\
\hline Water Flow (Oxygen Activation) & $\begin{array}{l}\text { Measure vertical fluid velocities } \\
\text { under pumping conditions }\end{array}$ & SWS & $10 / 25 / 93$ & WF-1 & $686.7(2,253)$ & $774.8(2,542)$ \\
\hline
\end{tabular}

\footnotetext{
a Depth below ground surface

b Atlas Wireline Services

c Schlumberger Wireline Services

d IT Corporation

e Barbour Well Surveying

$f$ Desert Research Institute
} 
This page intentionally left blank. 


\subsection{Geology}

The geology of Well UE-10j was originally described by the USGS in 1965 (Ege et al.,1965), and later revised by LLNL (McArthur, 1979). For the recompletion, samples from the upper part of the hole were not redescribed: only the stratigraphic nomenclature and some lithologic unit depths were revised from these sources. The geology of the deepened portion of the well was described using rotary sidewall cores and geophysical logs, as only one poor drill cuttings sample was available. The following is a discussion of the geology of UE-10j from the surface to the recompletion TD, and thus, is a compilation of the geologic information from the original well and the recompleted well. Stratigraphic and lithologic logs for Well UE-10j can be found in Appendix C of this report.

Well UE-10j is located in extreme northern Yucca Flat just south of the Smoky Hills (Figure 1-2). The surface geology at Well UE-10j consists of Quaternary/Tertiary-age alluvial deposits composed of debris shed from the surrounding mountains. The well penetrated $32 \mathrm{~m}$ (106 ft) of Quaternary/Tertiary-age alluvium, $280 \mathrm{~m}$ (918 ft) Tertiary-age volcanic rocks, and $484 \mathrm{~m}(1,589 \mathrm{ft})$ of Cambrian-age sedimentary rocks. The Cambrian-age sedimentary rocks encountered are part of the hydrostratigraphic unit known as the lower carbonate aquifer (Winograd and Thordarson, 1975).

Well UE-10j penetrated alluvium consisting of sandy gravel from the surface to $32 \mathrm{~m}$ (106 ft). This alluvium overlies $77 \mathrm{~m}(252 \mathrm{ft})$ of bedded tuff assigned to the Tunnel Formation which was penetrated from 32 to $109 \mathrm{~m}$ (106 to $358 \mathrm{ft}$ ). This unit in turn overlies peralkaline bedded tuff of the Tub Spring Tuff which was penetrated from 109 to $116 \mathrm{~m}$ (358 to $381 \mathrm{ft}$ ). Seventy-four meters $(242 \mathrm{ft})$ of bedded tuff assigned to the informal tunnel beds units 1 and 2 were penetrated below the Tub Spring Tuff from 116 to 190 m (381 to $623 \mathrm{ft}$ ). The Redrock Valley Tuff, a partially welded ash-flow tuff $20 \mathrm{~m}$ (66 ft) thick, directly underlies tunnel beds 1 and 2 at Well UE-10j, and was penetrated from 190 to $210 \mathrm{~m}$ (623 to $689 \mathrm{ft}$ ). Below the Redrock Valley Tuff, $18 \mathrm{~m}(59 \mathrm{ft})$ of undifferentiated bedded tuff was penetrated from 210 to $228 \mathrm{~m}$ (689 to $748 \mathrm{ft})$. This bedded tuff overlies $82 \mathrm{~m}$ (269 ft) of partially welded ash-flow tuff assigned to the tuff of Twin Peaks which was penetrated from 228 to $310 \mathrm{~m}$ (748 to 1,017 ft). Directly underlying the tuff of Twin Peaks is $2 \mathrm{~m}(7 \mathrm{ft})$ of undifferentiated argillized bedded tuff, which was penetrated from 310 to $312 \mathrm{~m}$ (1,017 to 1,024 ft). This relatively thin unit forms the basal Tertiary volcanic unit in Well UE-10j. 
The basal Tertiary unit unconformably overlies Cambrian-age dolomite of the Smoky Member of the Nopah Formation. The Smoky Member is $176 \mathrm{~m}$ (576 ft) thick in Well UE-10j and was penetrated from 312 to $488 \mathrm{~m}$ (1,024 to 1,600 ft). The Halfpint Member of the Nopah Formation was penetrated below the Smoky Member, from 488 to $590 \mathrm{~m}$ (1,600 to 1,936 ft) for a thickness of $102 \mathrm{~m}$ ( $336 \mathrm{ft}$ ). This Cambrian-age dolomite overlies $56 \mathrm{~m}$ (183 ft) of the Dunderberg Shale Member of the Nopah Formation which was penetrated from 590 to $646 \mathrm{~m}$ (1,936 to 2,119 ft). The Dunderberg Shale Member is the lower member of the Nopah Formation and appears to conformably overlie the Banded Mountain Member of the Bonanza King Formation. Well UE-10j reached TD in the Banded Mountain Member after penetrating $150 \mathrm{~m}$ (494 ft) of the unit between the depths of 646 and $796 \mathrm{~m}$ (2,119 to 2,613 ft). The Banded Mountain Member consists of interbedded dolomite and limestone in the upper part and dolomite in the lower part. The unit appears to be pervasively fractured, especially below approximately $722 \mathrm{~m}$ $(2,370 \mathrm{ft})$ where several large fracture-induced borehole breakouts are present.

The geology encountered during the deepening of Well UE-10j from its original TD of $725 \mathrm{~m}$ (2,380 ft) to $796 \mathrm{~m}(2,613 \mathrm{ft})$ was as predicted prior to recompletion operations. The hole originally bottomed in the Banded Mountain Member of the Bonanza King Formation after penetrating $79 \mathrm{~m}$ ( $260 \mathrm{ft}$ ) of the unit. The Banded Mountain Member can be up to $744 \mathrm{~m}$ (2,440 ft) thick (Barnes et al., 1963), thus it was predicted that the recompleted well would remain in the Banded Mountain Member and also bottom in this unit even if the hole had reached

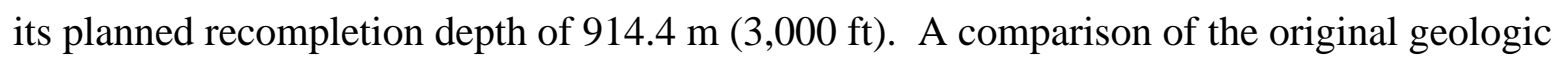
interpretation of the upper part of the hole and the predicted geology of the deepened portion with the revised geologic interpretation of the entire recompleted well is shown in Figure 4-1. 


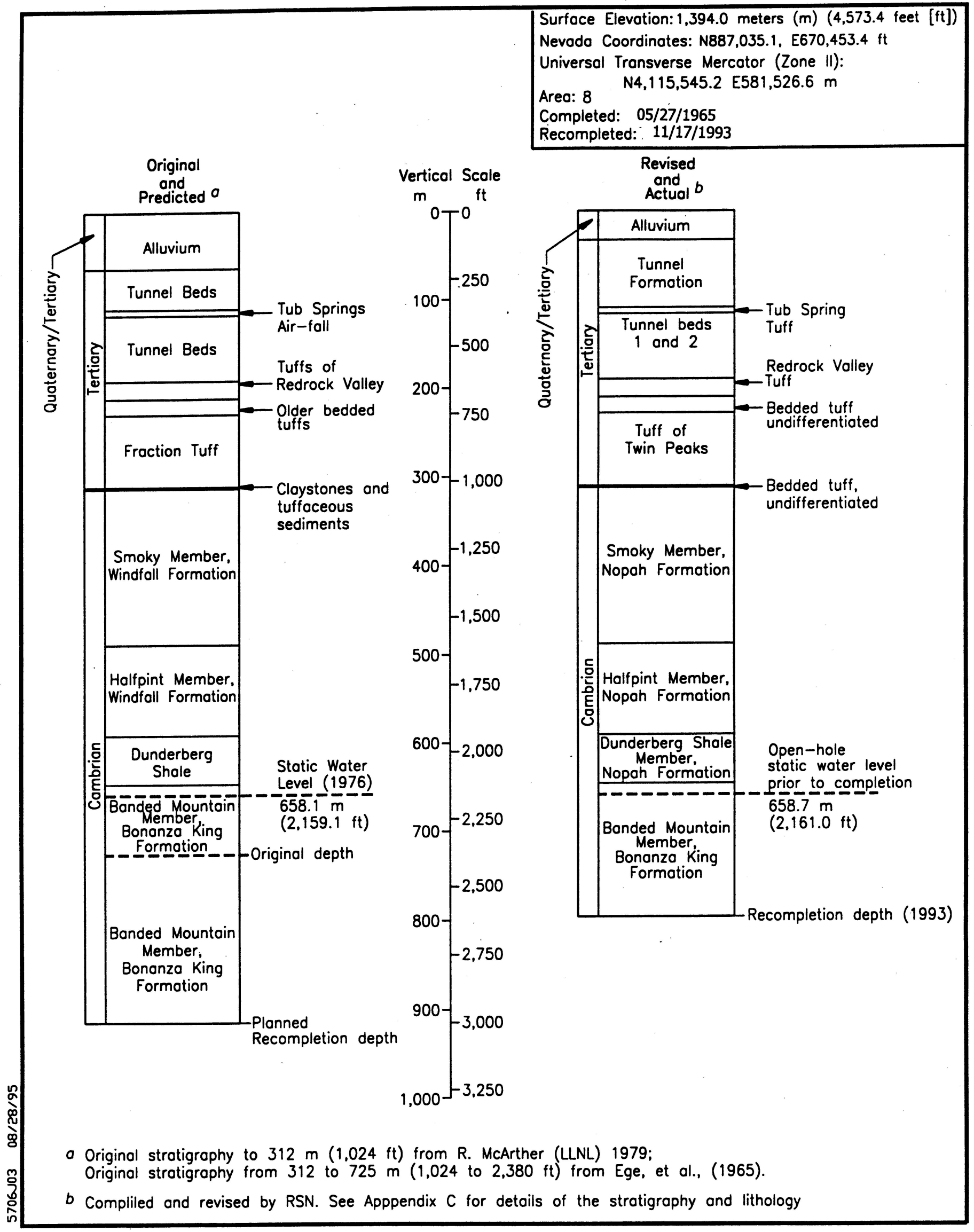

Figure 4-1

Predicted and Actual Stratigraphy of Well UE-10j 
This page intentionally left blank. 


\subsection{Hydrology}

\subsection{Water-Level Information}

Well UE-10j was drilled originally to gain geologic and hydrologic information on the lower carbonate aquifer in northern Yucca Flat. At least seven open-hole water-level measurements were made by the USGS between 1965 and 1976, and all these measurements indicated depth to water between 657.9 and $659.6 \mathrm{~m}$ (2,158.4 and 2,164.0 ft) (IT, 1995). The last measurement made in the hole before access to the water table was lost due to borehole sloughing or bridging indicated a static water level at a depth of $657.8 \mathrm{~m}(2,158 \mathrm{ft})$ in 1976 . A fluid-level measurement made in the open borehole during recompletion drilling indicated a depth to water of $657.8 \mathrm{~m}$ $(2,158 \mathrm{ft})$ on February 12, 1993. Measurements made in the open borehole after drilling and before development indicated depths to water of 658.7 and $657.8 \mathrm{~m}(2,161$ and 2,158 ft) on March 18 and 22, 1993, respectively (IT, 1995).

\subsection{Thermal Flow Meter Data}

Thermal flow meter (TFM) data, along with temperature, electrical conductivity, and $\mathrm{pH}$ measurements can characterize borehole fluid variability, which may indicate inflow and outflow zones. Desert Research Institute personnel developed a fluid-diversion packer for use with their flow meter and made TFM measurements at seven discrete depths in Well UE-10j after drilling was completed and prior to open-hole development. The results of their tests indicated relatively uniform, low upward flow from the bottom of the hole to approximately $716 \mathrm{~m}(2,349 \mathrm{ft})$, increased flow that correlates with an observed fracture at $705 \mathrm{~m}(2,312 \mathrm{ft})$, and a zone of outflow between 695 and $705 \mathrm{~m}$ (2,280 and 2,312 ft) that correlates with an interval of potentially fractured rock. A detailed discussion of the TFM method, equipment used, and UE-10j results, is given in Lyles (written communication, 1993).

\subsection{Hydrologic Testing}

Precompletion, open-hole development was conducted at Well UE-10j, followed by hydrologic testing. Hydrologic testing at Well UE-10j included pumping tests, oxygen-activation flow logging, and straddle-packer testing. The results of these tests and discussions of the well hydrology are provided in the Precompletion Hydrologic Testing Documentation Package for Well UE-10j (IT, 1995). 
This page intentionally left blank. 


\subsection{Precompletion and Open-Hole Development}

\subsection{Introduction}

Open-hole development of Well UE-10j was initiated immediately after TD was reached in an effort to restore the hydrologic system to its predrilling condition. The development process, which includes cleaning and purging the well of drilling fluids and stabilizing water quality parameters, is thought to repair damage to the formation from drilling and improve the hydraulic efficiency of the formation immediately around the borehole. In addition, it was thought that development would help establish pumping rates for later hydrological testing.

Air-lifting was specified for development in the Re-Completion Plan for GCP UE-10j (RSN, 1992) and the Recompletion Criteria for Well UE-10j (IT, 1992). However, because of low production during this process, development was continued by means of pumping concurrently with the subsequent hydrologic testing. The drilling history illustrated in Figure 2-1 shows the timing of air-lift development relative to drilling and completion activities; the hydrologic testing history is charted in Figure 6-1.

The initial development of the well was performed on three zones between February 25 and March 1, 1993. The zones encompassed wash-outs that had been identified from caliper and density logs and from the televiewer log:

- Zone $1-690.1$ to $691.9 \mathrm{~m}(2,264$ to $2,270 \mathrm{ft})$

- Zone 2 - 737.0 to $739.4 \mathrm{~m}(2,418$ to $2,426 \mathrm{ft})$

- Zone $3-763.8$ to $766.3 \mathrm{~m}(2,506$ to $2,514 \mathrm{ft})$

Figure 6-2 shows the configuration of Well UE-10j at the time of open-hole development and the locations of the selected development intervals.

\subsection{Well-Development Methods}

\subsubsection{Air-Lift Pumping}

The air-lift, or "dipstick," method of development (Driscoll, 1986) uses compressed air delivered down an air-line to lift water up an eductor pipe. The method, as practiced on Well UE-10j, is 
This page intentionally left blank. 


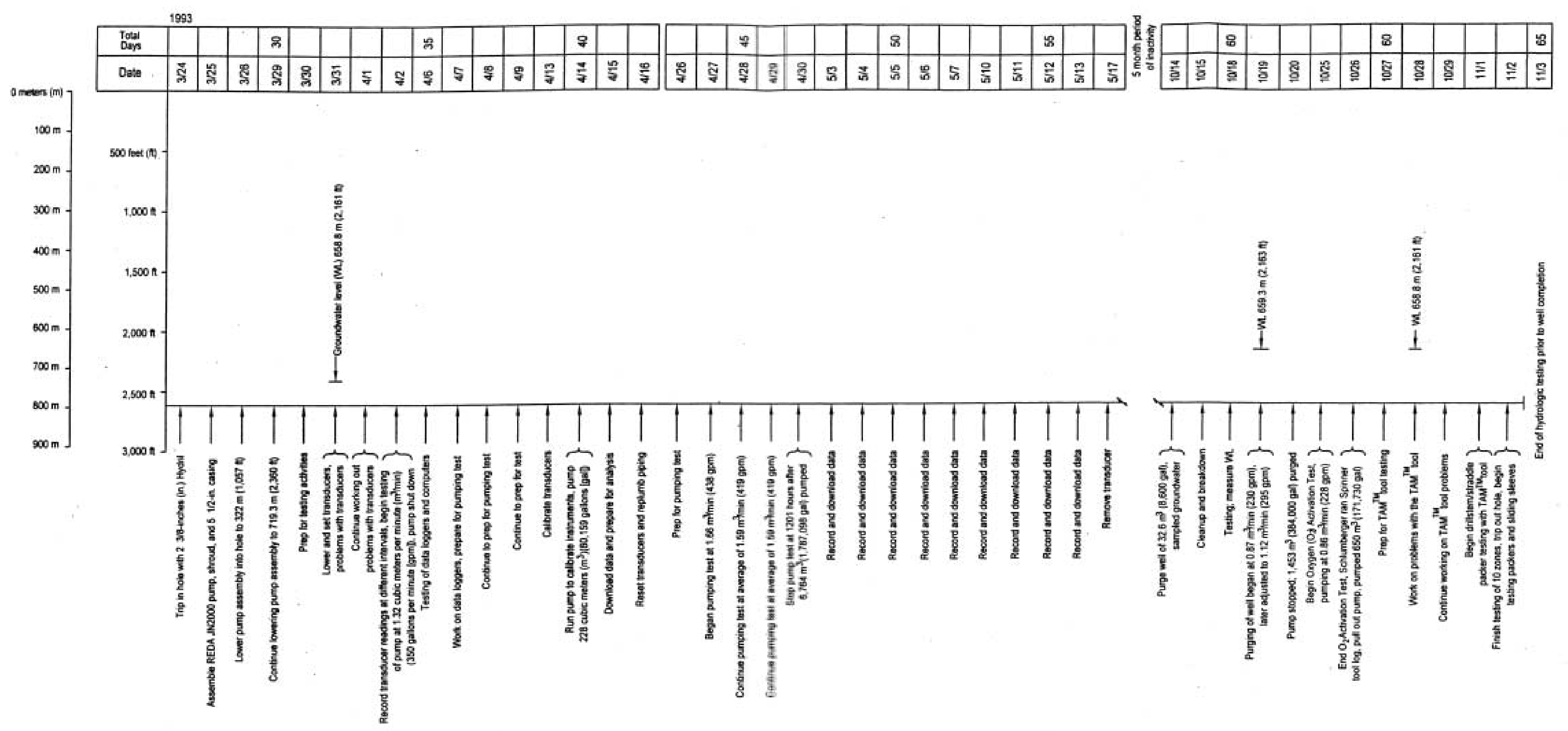

FIGURE 6-1 
This page intentionally left blank. 


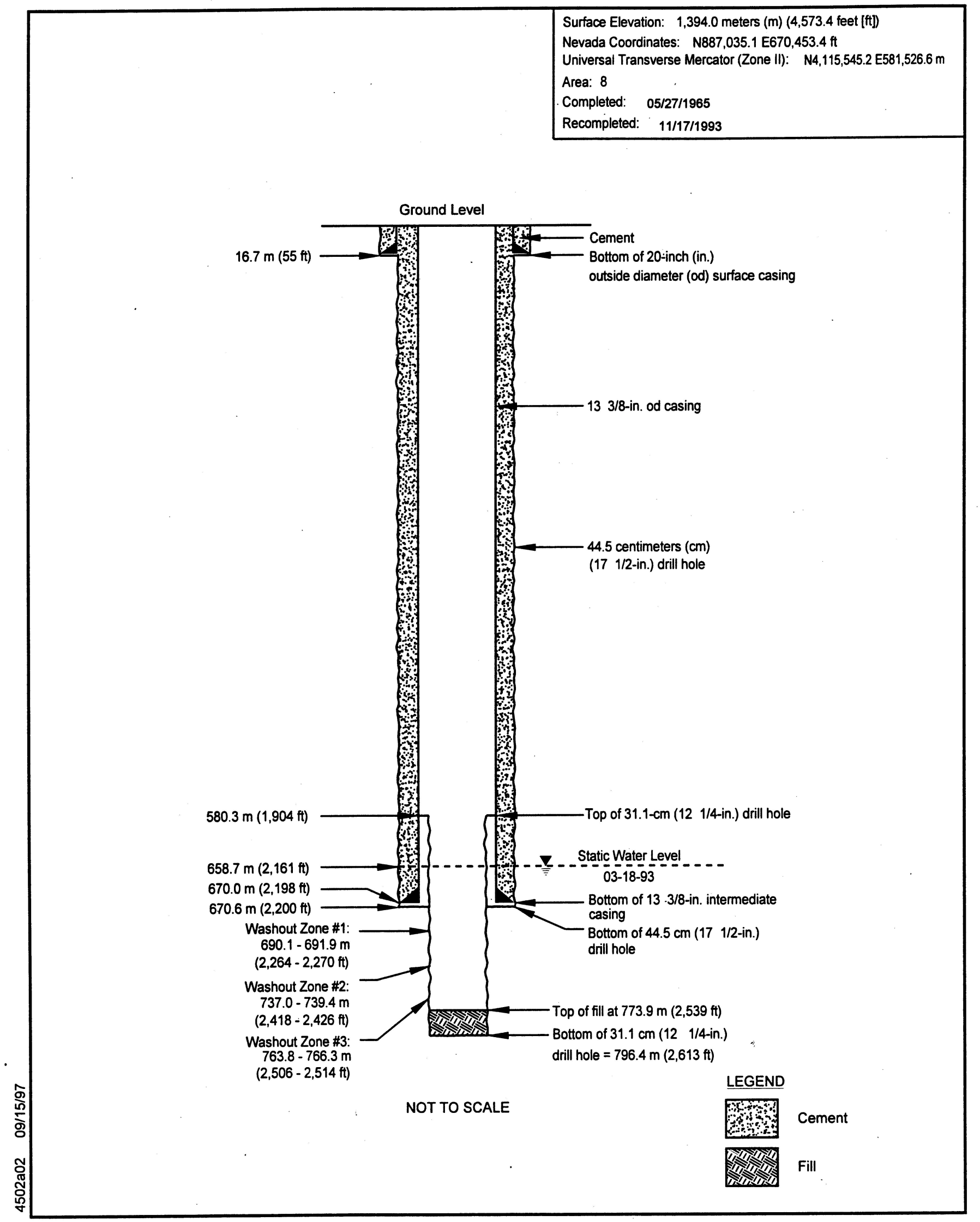

Figure 6-2

Schematic for Well UE-10j Showing Washout Zones Selected for Development 
schematically illustrated in Figure 6-3. The following equipment was used during the air-lift process:

- Two air compressors capable of producing $2.3 \mathrm{MPa}$ (340 psi)

- $6 e$-in. drilling pipe used as the eductor (water-discharge) pipe

- 1.9-in. Hydril tubing with 0.04-cm (d -in.) diameter slots at the bottom, used as the air-line

- An air separator at the water discharge location

The dipstick assembly, consisting of the air-line and the eductor pipe (as illustrated in Figure 6-3), was raised and lowered to develop different intervals. The actual level being developed at any one time is at the bottom of the air-line, represented by the "Z" in Figure 6-3. The requirements for successful air-lifting depend on the total lift (fluid level to land surface), percentage submergence (fluid level to air-line discharge level), area of the annulus (between airline and eductor pipe), and the capacity of the air compressor. The critical factor at Well UE-10j was the percentage submergence. In wells where lift is greater than $61 \mathrm{~m}(200 \mathrm{ft})$, good results usually require a percentage submergence of 30 percent or greater, though acceptable results can be attained at submergences as low as 10 percent. In Well UE-10j, the percent submergence ranged from 4.6 percent in Interval 1 to 14.6 percent in Interval 3, which probably explains why there were no returns while developing Interval 1.

Development started at Interval 1 with the bottom of the dipstick assembly set at $688.8 \mathrm{~m}$ $(2,260 \mathrm{ft})$. Very few returns were produced from this zone. The assembly was then lowered to $695.2 \mathrm{~m}(2,281 \mathrm{ft})$ to develop Interval 2. The assembly was lowered to $707.1 \mathrm{~m}(2,320 \mathrm{ft})$ where the discharge rate was 0.04 cubic meters per minute $\left(\mathrm{m}^{3} / \mathrm{min}\right)$ (10 gallons per minute) [gpm]). Production increased to 0.07 to $0.1 \mathrm{~m}^{3} / \mathrm{min}$ (17.5 to $25 \mathrm{gpm}$ ) when the assembly level was lowered to $744 \mathrm{~m}(2,441 \mathrm{ft})$. The assembly was raised and lowered to find the best production depth, and the 744-m (2,441-ft) level proved to be the optimal depth.

For development of Interval 3, the assembly was lowered to $755 \mathrm{~m}(2,477 \mathrm{ft})$ with the bottom of the eductor pipe at $771.1 \mathrm{~m}(2,530 \mathrm{ft})$. Optimal production was obtained by raising the assembly to $748.6 \mathrm{~m}(2,456 \mathrm{ft})$. The discharge rate ranged from 0.05 to $0.08 \mathrm{~m}^{3} / \mathrm{min}$ (11.8 to $\left.20 \mathrm{gpm}\right)$ during development of Interval 3. The groundwater was described as clean but soapy during the last eight hours of development.

The initial development produced 105.6 cubic meters $\left(\mathrm{m}^{3}\right)$ (27,902 gallons [gal]) of groundwater, which was transferred into lined sump \#1. The water eventually evaporated. 


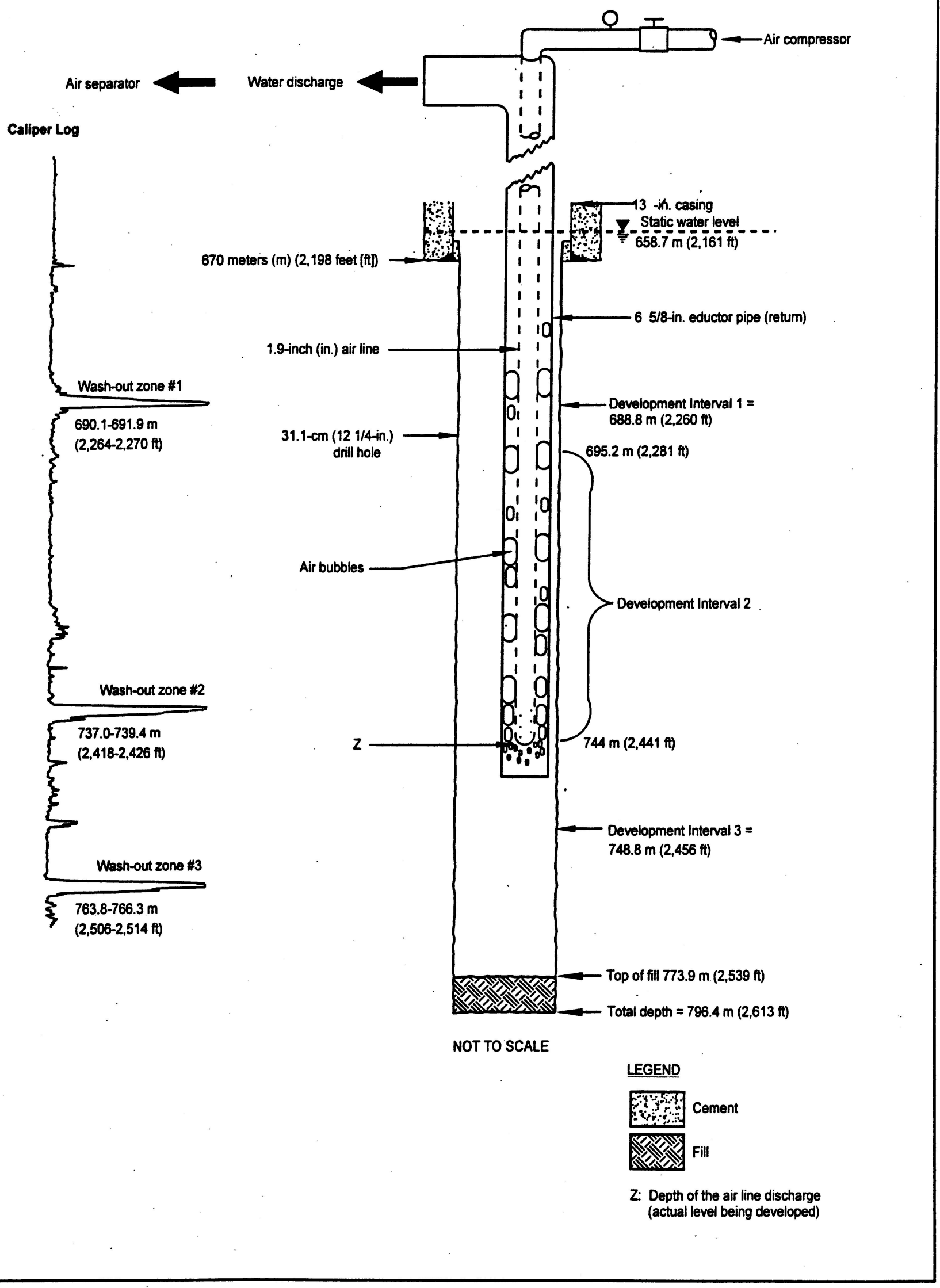

Figure 6-3

Diagram of Dipstick (Air-Lift) Method of Development With Caliper Log for Well UE-10j 


\subsubsection{Development Pumping}

Between March 31 and May 5, 1993, a submersible pump was set in the well and hydrological tests were conducted (Figure 6-1) The pump used was a REDA JN2000 submersible pump with the intake at $716.3 \mathrm{~m}(2,350 \mathrm{ft})$. The pump was tested at pumping rates from 1.32 to $1.60 \mathrm{~m}^{3} / \mathrm{min}$ (350 to 415 gpm). A 72-hour pumping test was conducted from April 27 through April 30, 1993, at a pumping rate of approximately $1.59 \mathrm{~m}^{3} / \mathrm{min}(420 \mathrm{gpm})$. A total of $6,764 \mathrm{~m}^{3}(1,787,098 \mathrm{gal})$ of groundwater was pumped from the well. All effluent was discharged into the sump and infiltration basin. A sample of the groundwater was taken at the end of the test and sent to a laboratory for a full suite of analyses. The hydrological testing results and water-chemistry data can be found in the Precompletion Hydrologic Testing Doumentation Package for Well UE-10j (IT, 1995).

After the pumping tests at Well UE-10j were completed in May 1993, recompletion operations were suspended until October 1993. 


\subsection{Completion}

\subsection{Introduction}

The objective of well completion is to hydraulically isolate water-producing zones within a borehole in order to collect potentiometric and water-chemistry data from the selected producing zones. Completion activities at Well UE-10j began on October 14, 1993, five months after the conclusion of drilling and testing. A completion string, designed with sliding sleeves and attached to a separate pumping string, was installed after purging of the hole and initial hydrologic testing. Access to the aquifer through the sliding sleeves will allow measurement of vertical gradients in the lower carbonate aquifer within the selected depth range. Completion activities were concluded on November 17, 1993. Figure 7-1 is a schematic of the final wellcompletion design for Well UE-10j and Figure 7-2 shows a plan view and profile of the wellhead surface completion. The recompletion and hydrologic testing histories are shown in Figures 2-1 and 6-1, respectively. Data for this section were obtained from IT field records, RSN daily drilling and tubing records, and from the hole history for Well UE-10j (F\&S, 1965).

\subsection{Hydrologic Testing}

Hydrologic testing at Well UE-10j resumed on October 14, 1993, and continued until November 2, 1993. Well purging, oxygen-activation flow logging (both using the REDA JN2000 pump installed in March 1993), and drill-stem testing took place during that time period. The purging produced $1,453 \mathrm{~m}^{3}$ (383,989 gal) at an average pumping rate of $1.11 \mathrm{~m}^{3} / \mathrm{min}$ (294 gpm). The oxygen-activation flow logging was conducted on October 25 and 26, 1993, during which groundwater was pumped from the well at a rate of $0.86 \mathrm{~m}^{3} / \mathrm{min}$ (228 gpm). Pumpage totaled $650 \mathrm{~m}^{3}(171,649 \mathrm{gal})$. Drill-stem testing was conducted in the open hole on November 1 and 2, 1993.

The details and results of the oxygen-activation logging and the drill-stem testing are presented in Precompletion Hydrologic Testing Documentation Package for Well UE-10j (IT, 1995). However, the drill-stem test results are discussed briefly here, as they provided important information for the final design of the well.

The drill-stem (straddle packer) tests were conducted using a TAM $^{\mathrm{TM}}$ Combination Tool equipped with two external packers and three transducers. The distance between the packers (the testing interval) was adjusted using pup joints. For each test, water was added to the drill stem and then released into the interval between the external packers. Pressure transducers recorded the 


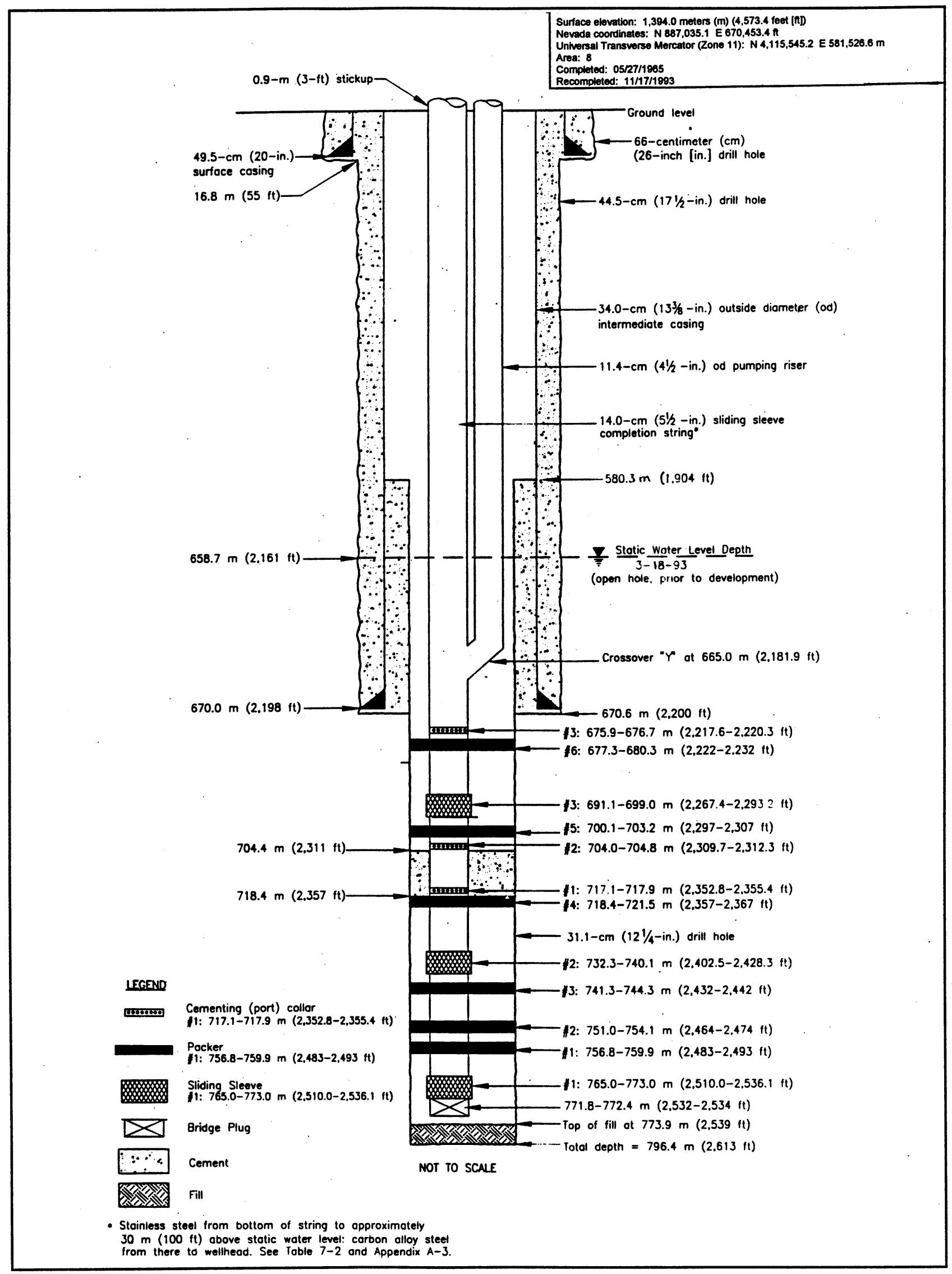

Figure 7-1

As-Built Schematic of Well UE-10j Completion String 


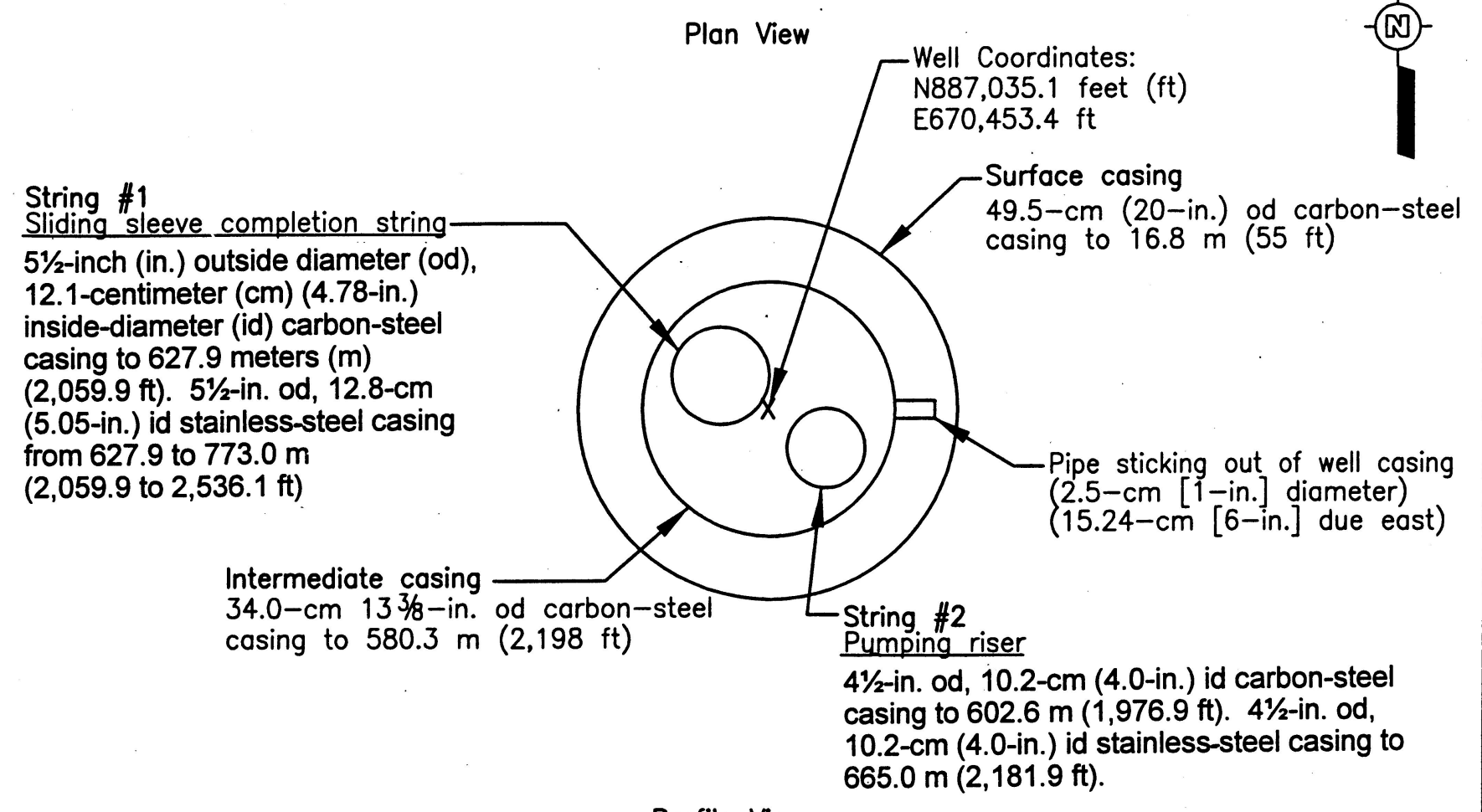

Profile View

String \#1

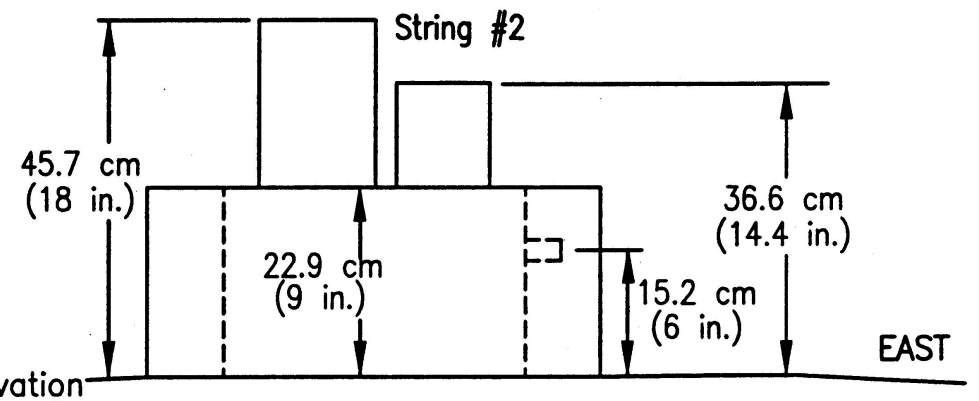

WEST Ground surface elevation $1,394.0 \mathrm{~m}(4,573.4 \mathrm{ft})$

String \#1

stick-up height $45.7 \mathrm{~cm}$ (18 in.) above ground surface, $22.8 \mathrm{~cm}$ (9 in.) above top of surface casing.

\section{SCALE}

String \#2

stick-up height $36.6 \mathrm{~cm}$ (14.4 in.) above ground surface, $21.4 \mathrm{~cm}$ (8.4 in.) above top of surface casing.

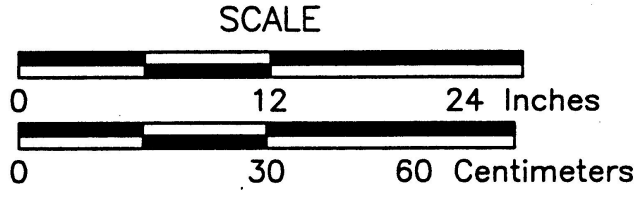

Figure 7-2

Well UE-10j Wellhead Diagram 
pressure differentials at three locations. The rate of pressure decay within the packers gives an indication of permeability of the surrounding formation.

Drill-stem tests were conducted at ten different intervals, and the results are given in Table 7-1. Areas of lower permeability (indicated by longer pressure-equalization times) were considered as potential locations for cementing and the placement of external packers on the completion string.

Table 7-1

Well UE-10j Drill-Stem (Straddle Packer) Test Results

\begin{tabular}{|c|c|c|c|c|c|}
\hline \multirow{2}{*}{$\begin{array}{c}\text { Test } \\
\text { Number }\end{array}$} & \multicolumn{2}{|c|}{ Interval Tested } & \multirow{2}{*}{$\begin{array}{l}\text { Length of } \\
\text { Interval } \\
\text { m (ft) }\end{array}$} & \multirow{2}{*}{$\begin{array}{l}\text { Time to } \\
\text { Equalize } \\
\text { Pressure } \\
\text { minutes }\end{array}$} & \multirow{2}{*}{$\begin{array}{c}\text { Area Tested } \\
\text { (see Figure 6-3 for } \\
\text { these zones) }\end{array}$} \\
\hline & meters (m) & feet $(\mathrm{ft})$ & & & \\
\hline 10 & 683.1 to 687.0 & 2,241 to 2,254 & $4.0(13)$ & 17 & $\begin{array}{c}\text { Above Wash-out } \\
\text { Zone \#1 }\end{array}$ \\
\hline 7 & 688.2 to 696.8 & 2,258 to 2,286 & $8.5(28)$ & 5 & Wash-out Zone \#1 \\
\hline 5 & 705.3 to 713.8 & 2,314 to 2,342 & $8.5(28)$ & 190 & $\begin{array}{c}\text { Just below Wash-out } \\
\text { Zone \#1 }\end{array}$ \\
\hline 4 & 711.4 to 719.9 & 2,334 to 2,362 & $8.5(28)$ & 300 & $\begin{array}{l}\text { Below Wash-out } \\
\text { Zone \#1 }\end{array}$ \\
\hline 6 & 719.3 to 727.9 & 2,360 to 2,388 & $8.5(28)$ & 6 & $\begin{array}{l}\text { Above Wash-out } \\
\text { Zone \#2 }\end{array}$ \\
\hline 9 & 730.0 to 733.9 & 2,395 to 2,408 & $4.0(13)$ & 3.5 & $\begin{array}{c}\text { Just above Wash-out } \\
\text { Zone \#2 }\end{array}$ \\
\hline 3 & 735.2 to 743.7 & 2,412 to 2,440 & $8.5(28)$ & 5 to 6 & Wash-out Zone \#2 \\
\hline 2 & 747.9 to 756.5 & 2,454 to 2,482 & $8.5(28)$ & 8 & $\begin{array}{l}\text { Small wash-out or } \\
\text { fault zone }\end{array}$ \\
\hline 8 & 757.4 to 761.4 & 2,485 to 2,498 & $4.0(13)$ & 30 & $\begin{array}{c}\text { Just above Wash-out } \\
\text { Zone \#3 }\end{array}$ \\
\hline 1 & 759.6 to 768.1 & 2,492 to 2,520 & $8.5(28)$ & 9 & Wash-out Zone \#3 \\
\hline
\end{tabular}

Notes: See Figure 6-2 for locations of the three main wash-out zones.

Data Sources: IT, 1993c, 1993d. 


\subsection{Well Completion Design}

\subsubsection{Proposed Completion Design}

The original design for the recompletion of Well UE-10j as stated in the Recompletion Criteria for Well UE-10j (IT, 1992) called for the following:

- The bottom zone to be isolated with external casing packers, with a sliding sleeve for access, a cement port for gravel pack emplacement, and silica sand for gravel pack material

- Cementing through a cementing port to fill the void between the two external packers above the lower screened interval

- Three additional screened intervals with sliding sleeves and gravel packs above the lower zones separated by cemented impervious zones.

\subsubsection{Actual Completion Design}

The revisions to the completion criteria are described in detail in Well UE-10j Completion, Testing, and Sampling Criteria, Revision 2 (IT, 1993b) and in Re-Completion Program for UGTA RI/FS Well UE-10j, Revision 1 (RSN, 1993a).

The well was designed to access those areas of the formation with maximum permeability. The three wash-out zones identified by caliper log and televiewer, 690.1 to $691.9 \mathrm{~m}(2,264$ to 2,270 ft), 737.0 to $739.4 \mathrm{~m}$ (2,418 to $2,426 \mathrm{ft})$, and 763.8 to $766.3 \mathrm{~m}$ (2,506 to $2,514 \mathrm{ft}$ ) (Figure 6-2), were obvious choices for screened intervals, as confirmed by the drill-stem tests. Well UE-10j was completed with a 51/2-in. string (String \#1) containing three sliding sleeves, three cement ports, and six external packers. A 41/2-in. string (String \#2) attached to String \#1 will house the pump. A schematic of the completion string is presented in Figure 7-1. The string compositions summarized here are listed in Table 7-2, and the tubing materials are listed in

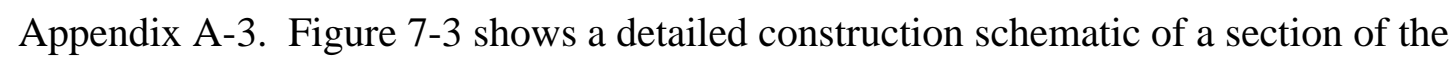
completion zone.

String \#1 is 51/2-in. stainless-steel tubing to approximately $31 \mathrm{~m}(101 \mathrm{ft})$ above the open-hole static water level (based on a static water level in the hole of approximately $658.7 \mathrm{~m}[2,161 \mathrm{ft}]$ ).

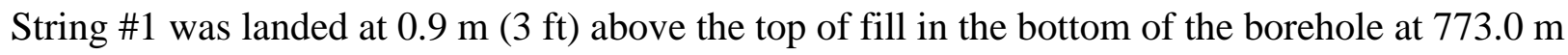
$(2,536.1 \mathrm{ft})$. The bottom $0.6 \mathrm{~m}(2 \mathrm{ft})$ of the string is a Baker bridge plug, which was set to replace the original bullnose welded to the bottom of the casing. It is thought the bullnose was blown off as the result of several cycles of "reversing out" cement in the $\mathrm{TAM}^{\mathrm{TM}}$ tool. 
Table 7-2

Well UE-10j Construction Material Summary

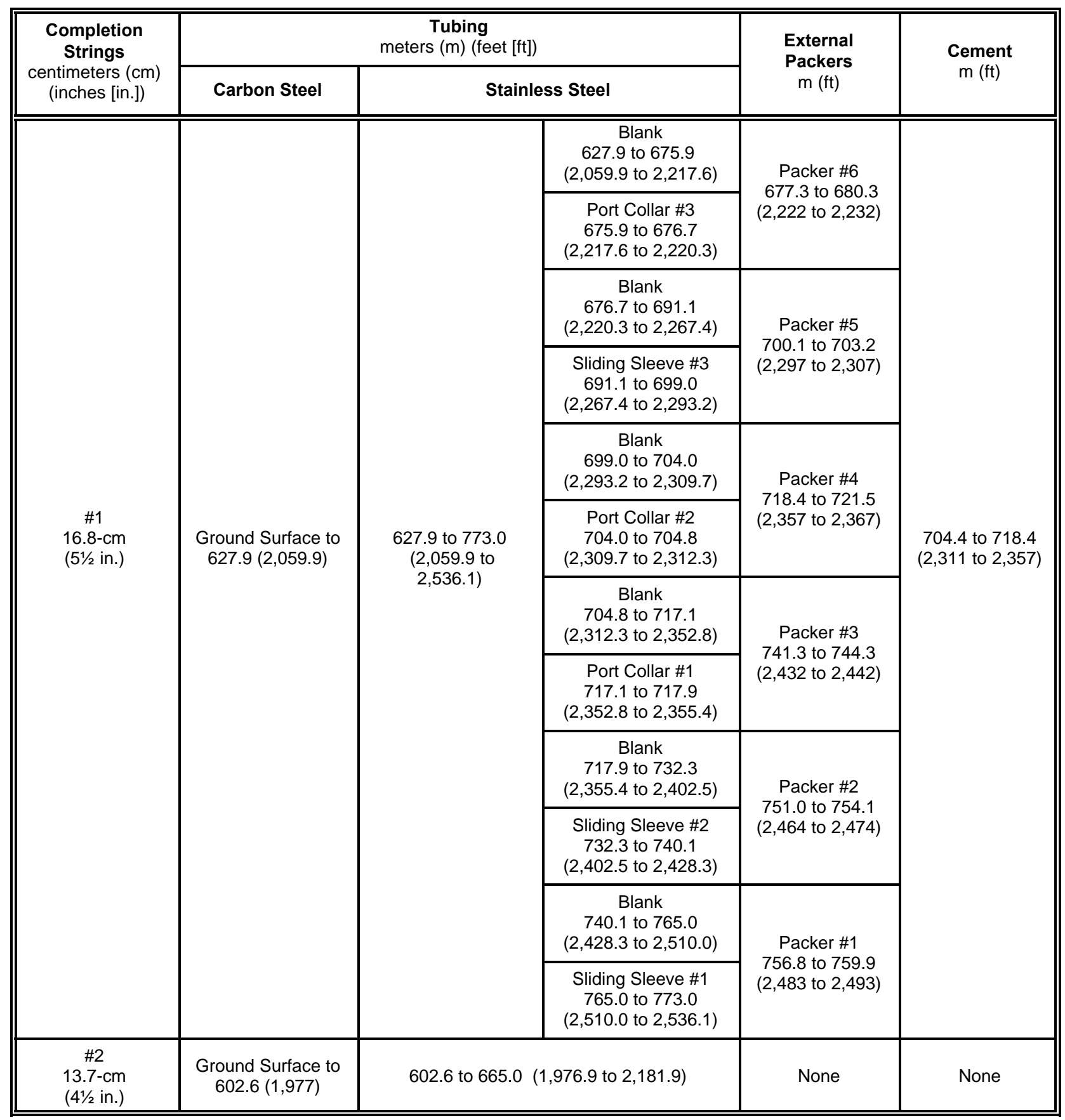

Notes: 1. No sand or gravel were emplaced in Well UE-10j.

2. Measured depths to water:

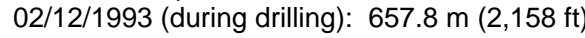

03/18/1993 (open borehole, before development): $658.7 \mathrm{~m}(2,161 \mathrm{ft})$

10/25/1993 (open borehole, prior to resumed hydrologic testing): $658.7(2,161 \mathrm{ft}$ ) 


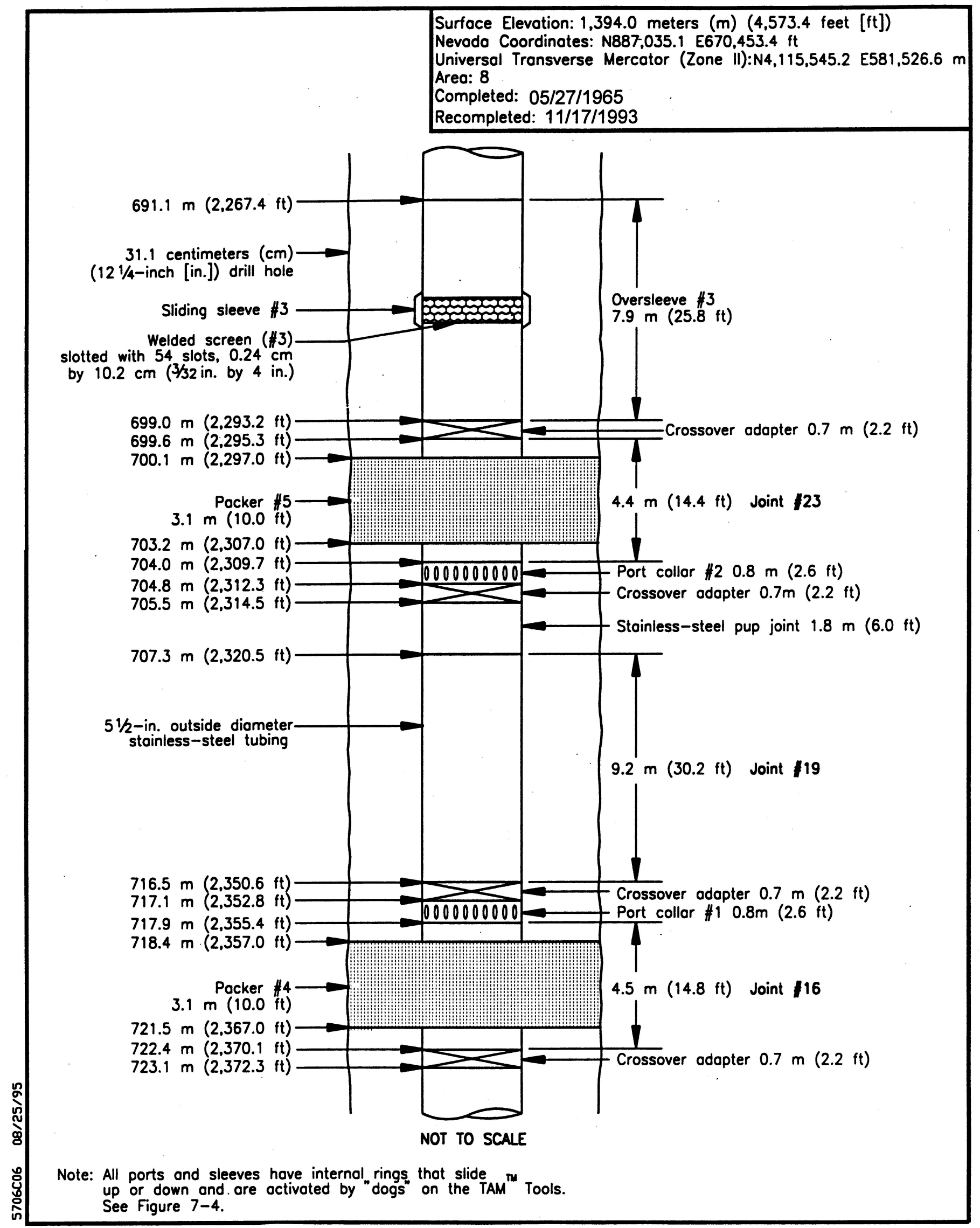

Figure 7-3

Construction Detail of Completion String of Well UE-10j 
"Reversing out" was accomplished by pumping potable, lithium-bromide-tagged water down the 51/2-in. casing; once sufficient pressure was built up in the casing, a choke opened on the bottom of the $\mathrm{TAM}^{\mathrm{TM}}$ tool, allowing the water to clean cement from the tool and tubing.

Sliding sleeve \#1 is positioned at the depth of 765.0 to $773.0 \mathrm{~m}(2,510.0$ to $2,536.1 \mathrm{ft})$ followed by a blank section $24.9 \mathrm{~m}(81.7 \mathrm{ft})$ long. Sliding sleeve \#2 is located at 732.3 to $740.1 \mathrm{~m}$

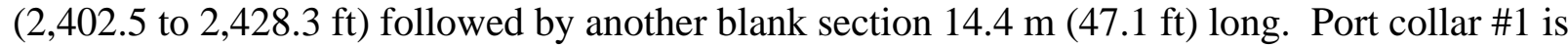
located above this blank section at the depth of 717.1 to $717.9 \mathrm{~m}(2,352.8$ to $2,355.4 \mathrm{ft})$, followed by another blank section $12.3 \mathrm{~m}(40.5 \mathrm{ft})$ long. Port collar \#2 is located at 704.0 to $704.8 \mathrm{~m}$ $(2,309.7$ to $2,312.3 \mathrm{ft})$, followed by another blank section $5.0 \mathrm{~m}$ (16.5 ft) long. Sliding sleeve \#3, the uppermost screened section, is located at the depth of 691.1 to $699.0 \mathrm{~m}(2,267.4$ to 2,293.2 ft) followed by a blank section $14.4 \mathrm{~m}(47.1 \mathrm{ft})$ long. The uppermost port collar, \#3, is located at the depth of 675.9 to $676.7 \mathrm{~m}$ (2,217.6 to $2,220.3 \mathrm{ft})$, and the remaining stainless-steel tubing is blank. Above the depth of $628.7 \mathrm{~m}(2,059.9 \mathrm{ft})$, the 51/2-in. string is made of carbon-steel tubing to the surface.

Each sliding sleeve assembly on String \#1 is $104.8 \mathrm{~cm}$ (41.25 in.) long with a maximum od of $16.0 \mathrm{~cm}$ (6.3 in.) and a maximum internal diameter of $12.7 \mathrm{~cm}$ (5.01 in.). Fifty-four slots, each 0.24 by $10.2 \mathrm{~cm}$ (0.09375 by 4 in.), provide access to the aquifer in each screened interval. An

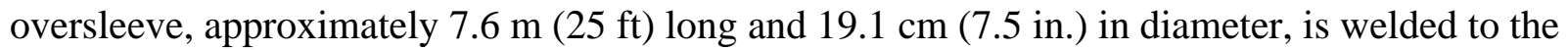
sliding sleeve casing. The oversleeves are intended to provide protection for the sliding sleeve assemblies and can be opened as needed for testing and sampling using the $\mathrm{TAM}^{\mathrm{TM}}$ Combination Tool.

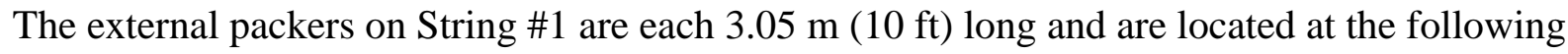
intervals:

Packer \#1: 756.8 to $759.9 \mathrm{~m}(2,483$ to $2,493 \mathrm{ft})$

Packer \#2: 751.0 to $754.1 \mathrm{~m}(2,464$ to $2,474 \mathrm{ft})$

Packer \#3: 741.3 to $744.3 \mathrm{~m}(2,432$ to $2,442 \mathrm{ft})$

Packer \#4: 718.4 to $721.5 \mathrm{~m}(2,357$ to $2,367 \mathrm{ft})$

Packer \#5: 700.1 to $703.2 \mathrm{~m}$ (2,297 to $2,307 \mathrm{ft})$

Packer \#6: 677.3 to $680.3 \mathrm{~m}$ (2,222 to $2,232 \mathrm{ft})$

The packers are made of steel-reinforced rubber and have an estimated life expectancy of 10 to 20 years. 
String \#2, which will be used to house the pump, consists of $4 \frac{1}{2} 2$-in. stainless-steel tubing from the bottom at $665.0 \mathrm{~m}(2,181.9 \mathrm{ft})$ to $602.6 \mathrm{~m}(1,976.9 \mathrm{ft})$, approximately $56.1 \mathrm{~m}(184.1 \mathrm{ft})$ above the static water level. A crossover wye connects the two strings at the bottom of the $4 \frac{1}{2}$-in. string, and this connection was strengthened by a gusset. String \#2 consists of $4 \frac{1}{2}-\mathrm{in}$. carbonsteel tubing from $602.6 \mathrm{~m}(1,976.9 \mathrm{ft})$ to the surface. This string was left open.

Cementing was planned for two intervals: between the fourth and fifth packers and above the sixth packer at the top of the completion string.

\subsubsection{Rationale for Differences between Actual and Proposed Well Design}

The above design was developed after drilling when it became apparent that the fracture zones and wash-outs in the carbonate rocks precluded using sand and gravel packing and cementing. The final well configuration was determined on the basis of the drill-stem test data, caliper and density logs, and the downhole televiewer data.

In addition to not using the standard gravel pack, the most significant change in the program was the addition of more external packers to separate a maximum of three completion zones. Also, a preinstalled tremie pipe was not needed to emplace sand and gravel.

\subsection{Well Completion Methods}

\subsubsection{Construction of Completion Strings}

Well-construction materials were inspected in accordance with relevant procedures before delivery to the drill site. Standard decontamination procedures were employed to prevent the introduction of contaminants into the well. The string was assembled at the wellhead and inserted into the borehole using a Class II drilling rig. The recompletion program for Well UE-10j called for strapping the 41/2-in. and 51/2-in. strings together (RSN, 1993a). However, numerous problems were encountered with this method, so the strings were attached by means of gussets welded onto the strings. After landing the completion string, a collar was welded at the wellhead. The 51/2-in. casing is probably stuck in the hole due to severe dog-legs in the drill hole (see Section 2.3 and Figure 2-2).

\subsubsection{Inflating Packers and Cementing}

Inflation of the packers and cementing of selected intervals in the well were accomplished using a $\mathrm{TAM}^{\mathrm{TM}}$ Combination Tool. Figure 7-4 is a diagram of the $\mathrm{TAM}^{\mathrm{TM}}$ tool showing a cross section 


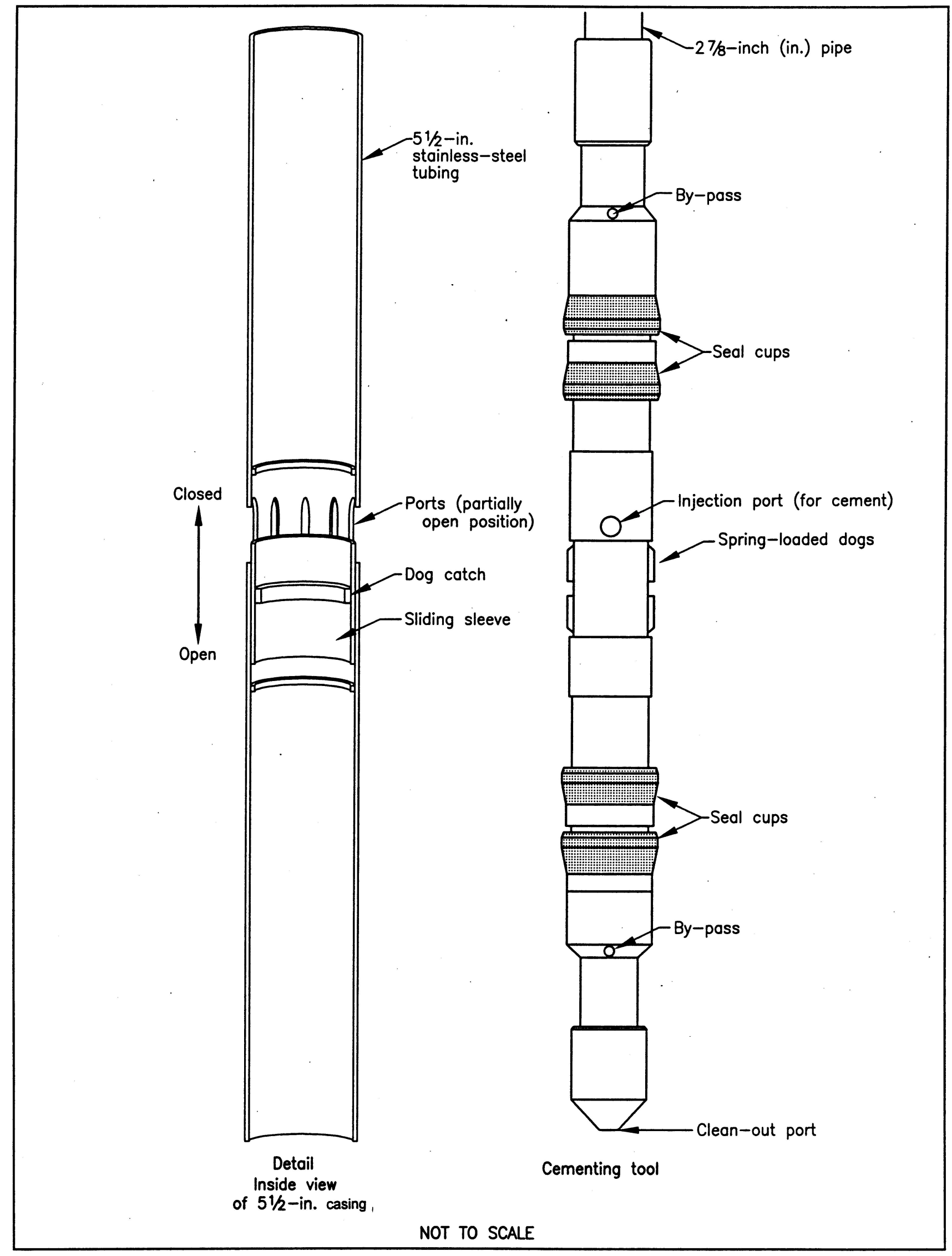

Figure 7-4

Simplified Drawing of TAM ${ }^{\mathrm{TM}}$ Combination Tool

(with detail of inside of $5 \frac{1}{2}$-inch casing and cross section of a cement port) 
of a cement port. The tool is used to open the sliding sleeve at the port, seal off the inside of the casing around the port with cup seals, and deliver the desired fluid to the port.

The six packers were inflated, in order from lowest to highest in the string, using water to a pressure of about $10.3 \mathrm{MPa}(1,500 \mathrm{psi})$.

Two intervals were targeted for cementing: (1) the interval between Packers \#4 and \#5; and (2) the interval above Packer \#6 (Figure 7-1). The initial attempt at cementing the interval between Packers \#4 and \#5 was not successful, but a second attempt delivered $0.85 \mathrm{~m}^{3}$ (30 cubic feet) of cement. A photon annulus investigation log (PAIL) was used to locate the top of the cement outside the casing. Based on the log response, it was determined that the cement rose about $14 \mathrm{~m}$ (46 ft) between the 51/2-in. casing and the borehole wall between Packers \#4 and \#5 on the second attempt. The effort to cement through the uppermost cement port was not successful.

The PAIL tool was used to tag the bottom of the completion string after cementing was completed. This log indicated that the bottom plate had fallen off the $51 / 2$-in. casing, which was later confirmed by a downhole camera survey. A Baker bridge plug packer was installed at the bottom of the casing to replace the bottom plate.

\subsubsection{Discussion}

The drill hole annulus outside each sliding sleeve screen is open directly to the formation. As no gravel/sand packs were emplaced, native fill can, and probably will, accumulate within each of the screened zones, although the oversleeves should prevent accumulation at the sliding sleeve assembly. The 3.05-m (10-ft) long packers are expected to hold the fill effectively and minimize direct hydraulic communication between the completion zones. There are at least two packers emplaced between each completion zone (Figure 7-1)

The cement plug installed between the fourth and fifth packers is expected to serve as an effective hydraulic barrier. Without the cement plug planned for placement above the sixth

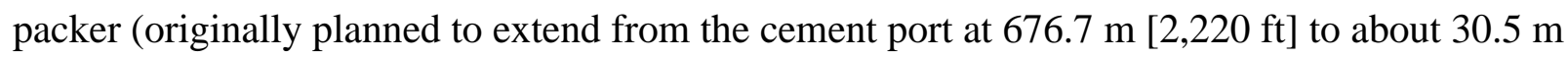
[100 ft] above the water table), there is only one packer above the third completion zone to serve as a hydraulic barrier.

It is not known why the cementing did not work or what happened to the cement in the two failed cementing attempts. Possibly, the cement bypassed the cementing tool seals and entered the 
casing. An explanation for cement loss in the zone above Packer \#6 is that the cement may have fractured the formation and been taken up by the resultant fracture(s). One problem with the tool was that the seals were damaged and had to be replaced several times. The probable cause of this damage was that the inside diameter of the 51/2-in carbon-steel casing was slightly smaller than that of the 51/2-in. stainless-steel casing. 


\subsection{Cost Summary}

The original work-order estimate for Well UE-10j projected that drilling, logging, and development would require 36 days to accomplish (RSN, 1993b, 1993c). The estimate for completion prepared by RSN in October 1993 projected that 19 days would be required to conduct hydrologic testing, additional geophysical logs, and well completion. The actual time spent on drilling and development activities through May 1993 was 60 days, and completion/ hydrologic testing activities (October and November 1993) required only 16 days, for a total of 76 days. The additional time spent on drilling includes approximately 35 one-shift days spent preparing for and conducting a pumping test as well as long-term monitoring.

The planned cost for site preparation, 36 days of drilling, logging, and development was $\$ 886,220$. The planned cost for 19 days of completion, testing, and materials was $\$ 650,478$. The total planned cost for the Well UE-10j recompletion was $\$ 1,536,698$.

The actual cost of the Well UE-10j recompletion project was $\$ 2,052,519$, or approximately 33.6 percent more than the planned cost. Table 8-1 provides a comparison of the actual versus predicted costs. Figure 8-1 is a comparison of the planned versus actual drilling and development costs, and Figure 8-2 is a comparison of the planned versus actual completion costs.

Table 8-1

Well UE-10j Projected versus Actual Costs

\begin{tabular}{||l|c|c|c||}
\hline \multicolumn{1}{|c|}{ Activity } & Planned Cost & Actual Cost & $\begin{array}{c}\text { Percent Difference } \\
\text { Actual versus Planned }\end{array}$ \\
\hline \hline $\begin{array}{l}\text { Drilling, geophysical logging and } \\
\text { development }\end{array}$ & $\$ 886,220$ & $\$ 1,403,275^{\mathrm{b}}$ & +58.3 \\
\hline $\begin{array}{l}\text { Hydrologic testing and } \\
\text { completion }\end{array}$ & $\$ 650,478$ & $\$ 649,244^{\mathrm{d}}$ & -0.2 \\
\hline Total & $\$ 1,536,698$ & $\$ 2,052,519$ & +33.6 \\
\hline
\end{tabular}

\footnotetext{
a Site preparation, drilling, and development activities through May 1993.

b Costs through September 1993 when the costs were closed.

c Activities in October and November 1993.

d Costs through September 1994 when costs were closed.
} 


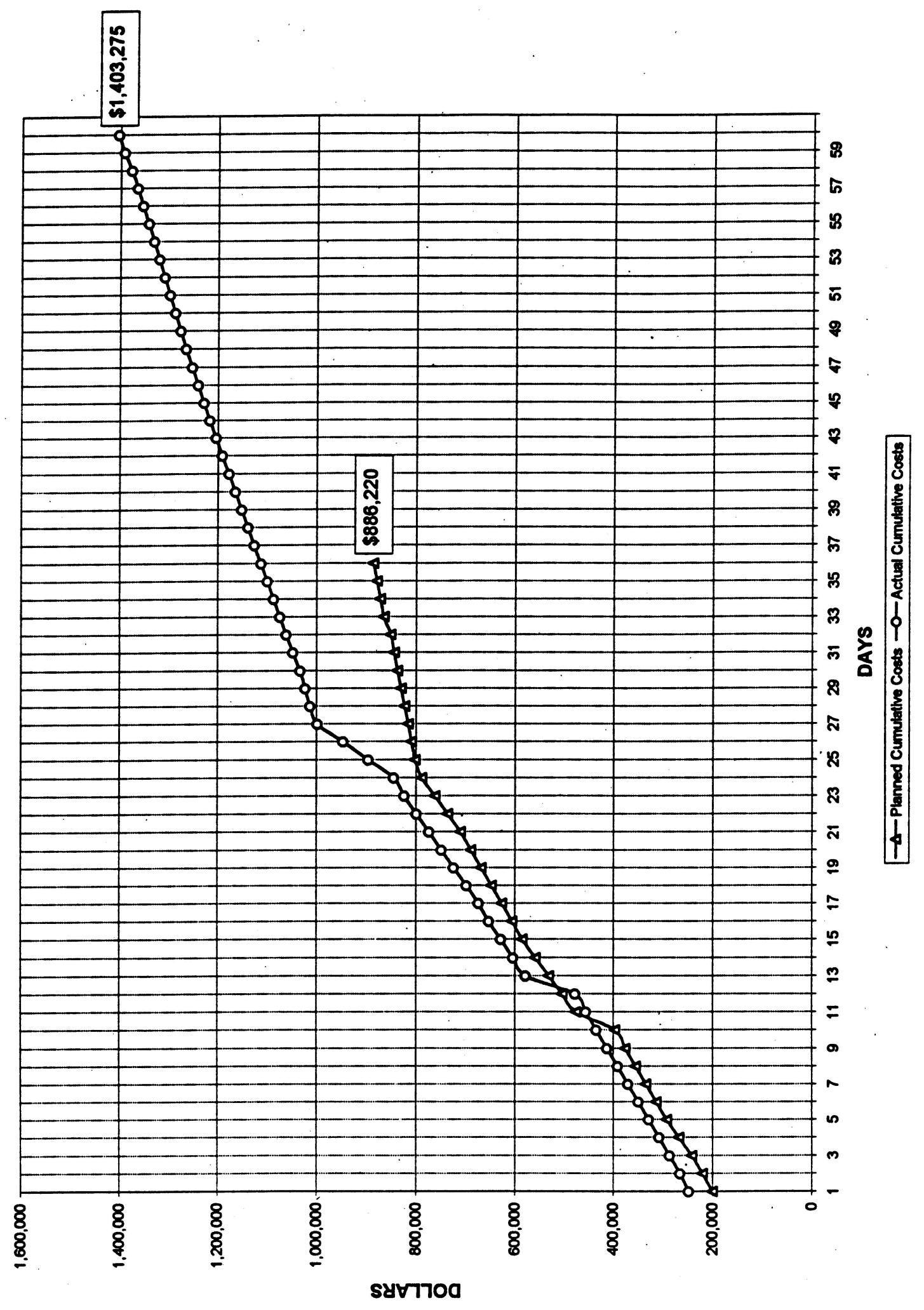

Figure 8-1

Planned versus Actual Costs for Drilling and Developing Well UE-10j 


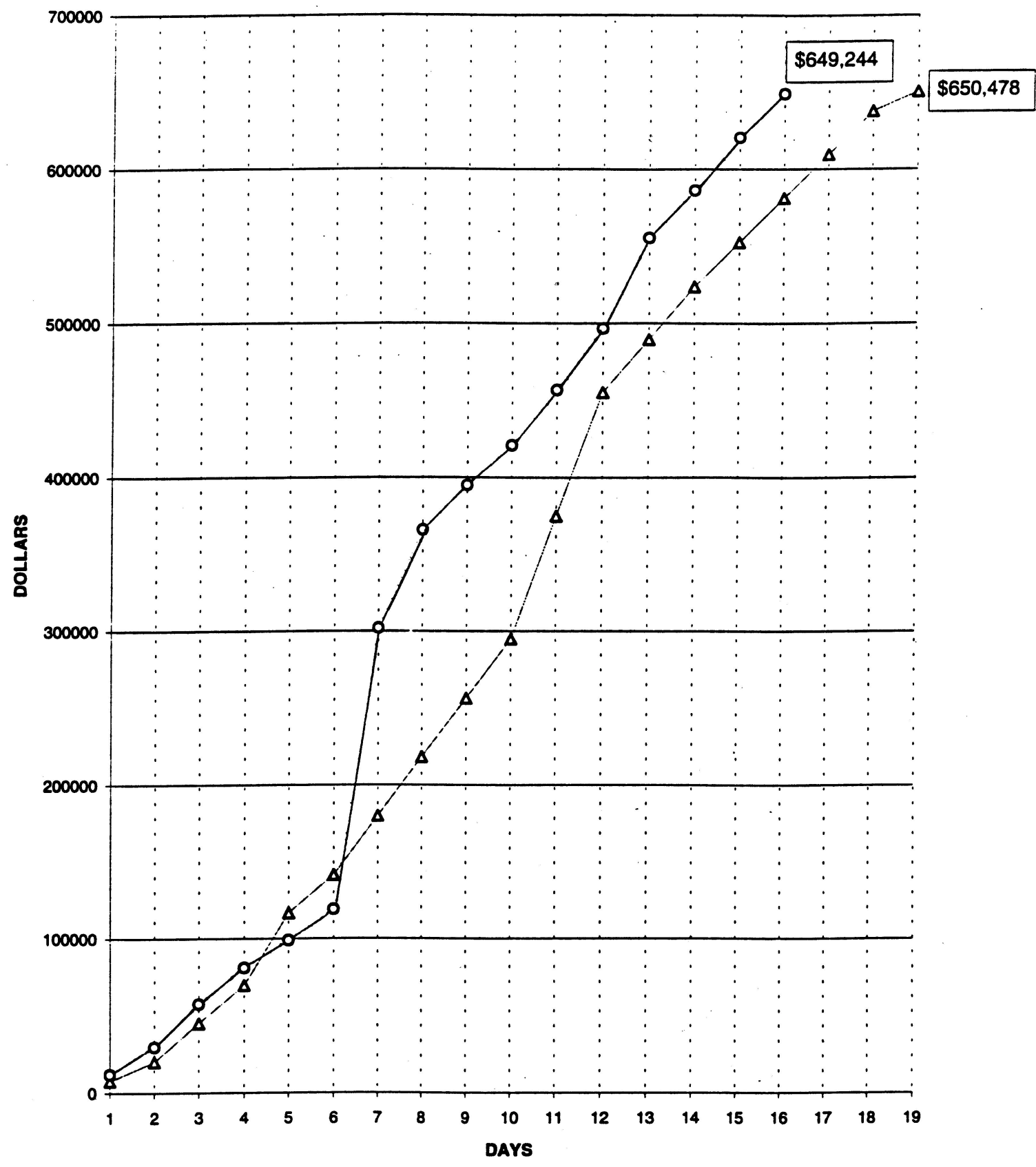

$\triangle$-PLANNED CUMULATIVE COST O ACTUAL CUMULATIVE COST

Figure 8-2

Planned versus Actual Costs for Recompletion of Well UE-10j 
This page intentionally left blank. 


\subsection{Summary, Recommendations, and Lessons Learned}

\subsection{Summary}

Well UE-10j was originally drilled in 1965 to a depth of $725.4 \mathrm{~m}(2,380 \mathrm{ft})$ and was left uncased to serve as a hydrologic test hole. Water level measurements were taken on several occasions until 1976. Interest in the hole reactivated in the late 1970s and early 1980s, when several geophysical logs were run in the hole. In 1981 it was found that due to hole sloughing or bridging the water table was inaccessible.

When recompletion operations began at Well UE-10j on January 27, 1993, the hole was reamed from its original $24.4-\mathrm{cm}$ (9e -in.) size to $44.5 \mathrm{~cm}(171 / 2$ in.) A $13 \mathrm{~d}$-in. casing was set at $670.0 \mathrm{~m}(2,198 \mathrm{ft})$ and the annulus was cemented to the surface. Cement was emplaced inside the casing to a depth of $580.3 \mathrm{~m}(1,904 \mathrm{ft})$, and drilling continued through the cement with a 121/4-in. bit to the total depth of the hole at $796.4 \mathrm{~m}$ (2,613 ft) on February 24, 1993.

Recompletion drilling at Well UE-10j was conducted using direct circulation; Davis Mix was used above the water table and air-foam was used below the water table. Circulation was lost at approximately $737 \mathrm{~m}(2,418 \mathrm{ft})$ and was never regained despite all efforts. Several wash-out zones were encountered during recompletion drilling, and drilling was finally halted because of increasing difficulty in keeping the hole free of fill. The hole was left with $22.6 \mathrm{~m}$ (74 ft) of fill, resulting in a working depth in the well of $773.9 \mathrm{~m}(2,539 \mathrm{ft})$.

Precompletion open-hole development and pump tests were conducted immediately after the conclusion of drilling. A fluid level of $658.7 \mathrm{~m}(2,161 \mathrm{ft})$ was measured in the open borehole in March 1993. Operations at Well UE-10j were suspended for five months, and then completion activities began in October 1993 with well-purging, oxygen-activation flow logging, and drillstem testing. Pumping of the well during purging and hydrologic testing removed almost $9,085 \mathrm{~m}^{3}\left(2.4 \times 10^{6} \mathrm{gal}\right)$ of water. The results of these tests were used to select the zones for well-completion activities, and on November 3, 1993, installation of two connected completion strings was begun. A 51/2-in. od casing containing six external packers and three screened intervals with sliding sleeves was landed near the bottom of the hole at $772.4 \mathrm{~m}(2,534 \mathrm{ft})$. This string is connected to a pumping riser made of $4 \frac{1}{2}$-in. tubing. The completion assembly was positioned such that the crossover wye connecting the two strings is located at the depth of

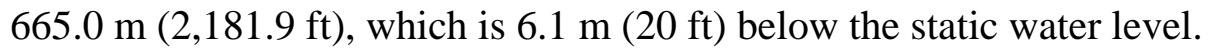


Screened intervals that provide access to three completion zones are located at the following depths: sliding sleeve \#1, 765.0 to $773.0 \mathrm{~m}$ (2,510.0 to 2,536.1 ft); sliding sleeve \#2, 732.3 to $740.1 \mathrm{~m}$ (2,402.5 to 2,428.3 ft); and sliding sleeve \#3, 691.1 to $699.0 \mathrm{~m}$ (2,267.4 to 2,293.2 ft). The six external rubber packers are positioned on the string, one above and one below each sliding sleeve, to isolate the three completion zones. The packers were inflated with water using the $\mathrm{TAM}^{\mathrm{TM}}$ Combination Tool, and two packer intervals were selected for cementing, also using the $\mathrm{TAM}^{\mathrm{TM}}$ tool. The interval 704.4 to $718.4 \mathrm{~m}(2,311$ to $2,357 \mathrm{ft})$, between completion zones \#2 and \#3, was not cemented on the first attempt; however, the second attempt was successful. The procedure was unsuccessful in the second cement interval, above the uppermost packer. Thus, only one packer is present above zone \#3 to serve as a hydraulic barrier. Completion zones \#1 and \#2 are separated by three packers.

Results of chemical analysis of drilling effluents indicated that all fluid-management objectives were met.

During recompletion drilling only one cuttings sample of poor quality was collected from Well UE-10j because of lost circulation below $737.0 \mathrm{~m}(2,418 \mathrm{ft})$. However, rotary sidewall core samples were collected at 13 locations. Geophysical logs were run periodically during drilling to aid in drilling and construction of the well, and after drilling was completed to aid in verification of the geology and the hydrologic characteristics of the rocks. Recompletion drilling penetrated only Paleozoic-age carbonate rocks.

The innovative completion methods planned for testing on this well were successfully implemented, though a few problems were encountered with the $\mathrm{TAM}^{\mathrm{TM}}$ cementing process. Well UE-10j was successfully completed, providing access to the three planned completion zones in the lower carbonate aquifer for future testing.

The total planned cost for the Well UE-10j recompletion was $\$ 1,536,698$. The actual cost was $\$ 2,052,519$, which is approximately 33.6 percent more than the estimated cost.

\subsection{Recommendations}

The following are recommendations for future work at Well UE-10j, required to accomplish the remaining recompletion goals: 
- Open, test, and evaluate the sliding sleeves.

- Install and test a pump in the $4 \frac{1}{2}-$-in. od casing.

- Continue well development, testing, and sampling operations. Develop the three completion zones, and sample the groundwater from each zone for water chemistry and radiological analysis.

- Measure the depth to water in each of the completion zones in the well.

- Implement the hydrological testing program; perform long-term pumping tests to quantify the hydrologic properties of the carbonate aquifer.

\subsection{Lessons Learned}

The following paragraphs describe lessons learned during drilling, testing, and construction of Well UE-10j. These lessons can be applied to other UGTA drilling projects as appropriate, to produce better scientific data at a reduced cost.

\subsubsection{Drilling and Development Procedures}

Future drilling through the Paleozoic rocks might be better facilitated with the use of the dualwall reverse-circulation method. At least three advantages to the dual-wall method can be visualized in this geologic setting: (1) the drill stem can push through voids or highly fractured areas, and circulation can be regained once more competent rocks are encountered; (2) the introduction of drilling muds and other circulation materials into the borehole can be curtailed; and (3) open-hole development could be performed with the drill stem.

The use of the dip-stick method for open-hole development of Well UE-10j was not effective. Development yielded a maximum of only about $0.06 \mathrm{~m}^{3} / \mathrm{min}(20 \mathrm{gpm})$, from a well that easily produced up to $1.6 \mathrm{~m}^{3} / \mathrm{min}(430 \mathrm{gpm})$ during pumping tests with a draw-down of only a few feet. The dip-stick method would be more effective if the well were deeper and more submergence of the dip-stick could be established.

\subsubsection{Materials}

The tubing for the two completion strings was found not to be clean enough when delivered to the drill site, which resulted in the use of unplanned time and transportation resources to take it back to the yard for additional cleaning. It was found that personnel were uncertain about inspection and release requirements. Procedures have now been developed to clarify standards and responsibilities in this area. 
Numerous problems were encountered with the banding method of attaching the two completion strings, so the strings were attached by means of gussets welded on to the strings. Time was lost to repair damaged threads on the wye between the 41/2-in. and 51/2-in. casings. Subs should be used for connections on wyes and spare wyes with subs should be ordered.

Delays and other problems arose as a result of inadequate materials, including the following:

- The plate welded on the bottom of the 51/2-in. casing was probably blown off as the result of "reversing out" the remnant cement in the $\mathrm{TAM}^{\mathrm{TM}}$ tool. It was recommended that the burst pressure rating for the threaded guide shoe on the bottom of casing be the same as that of the casing.

- The inside diameters of the carbon-steel and stainless-steel sections of the $5 \frac{1}{2} 2$-in. casing were different enough that the restriction at the cross-over caused damage to tools run inside the tubing. Weights and inside diameters of tubing should be specified in the program, so that they are within the known ranges of down-hole tools.

\subsubsection{TAM ${ }^{\mathrm{TM}}$ Tool and Cementing}

Two components in the $\mathrm{TAM}^{\mathrm{TM}}$ Combination Tool failed (converter, transducers), resulting in delays while parts were evaluated and replaced. Spares of all such components should be provided with the equipment. Also, components should be tested before going down-hole or while still in the upper portion of the hole to minimize time spent retrieving equipment from the hole.

The pressure cups on the $\mathrm{TAM}^{\mathrm{TM}}$ tool were damaged inside the $51 / 2$-in. casing. Several conditions contributed to this problem, in addition to the presence of gaps and shoulders inside the tubing (Section 9.3.2). Dog-legs in the hole made an already tight fit even more difficult to deal with. The greater-than-usual deviation of the hole was known prior to completion and should have been taken into account during design of completion hardware. In addition, the wrong size pressure cups had been sent. A more thorough review of pipe specifications and other conditions should be made with the vendor to avoid this type of problem.

The first cementing attempt resulted in over-displacement of cement. In the next attempt the balanced plug method was used successfully. The drilling engineer recommended that this method be used when attempting to circulate through cement ports. 
The cement was lost in the third cementing attempt, possibly to the formation through fractures above the port. This type of problem is not predictable, but the drilling engineer recommended that a lightweight, thixotropic cement be investigated for similar jobs in the future. 
This page intentionally left blank. 


\subsection{References}

Barnes, H., F. N. Houser, and F. G. Poole, 1963. Geologic Map of the Oak Spring Quadrangle, Nye County, Nevada, U.S. Geological Survey Map GQ-214, Washington, D.C.

Driscoll, F. G., 1986. Groundwater and Wells, Second Edition, Johnson Division: St. Paul, MN.

Ege, J. R., L. Chase, and F. M. Byers, Jr., 1965. "Preliminary Lithologic Log of Exploratory Hole UE-10j, Yucca Flat, NTS," U.S. Geological Survey Technical Letter NTS-141, Denver, CO.

Fenix \& Scisson, Inc., 1965. UE-10j Hole History, with Additional Work sheets for 1976, 1977, 1981, and 1983. Additional Work sheets included for 1992 and 1993, prepared by Raytheon Services Nevada, Las Vegas, NV.

Ferguson, J. F., A. H. Cogbill, and R. G. Warren. 1994. "A Geophysical-Geological Transect of the Silent Canyon Caldera Complex, Pahute Mesa, Nevada." Journal of Geophysical Research, Vol. 99, No. B3, pp. 4,323 - 4,339. American Geophysical Union: Washington, D.C.

F\&S, see Fenix \& Scisson, Inc.

IT, see IT Corporation.

IT Corporation, 1992. Recompletion Criteria for Well UE-10j, November 1992, Las Vegas, NV.

IT Corporation, 1993a. Fluid Management Plan for Saturated-Zone Operations at Well UE-10j, Revision 3, May 1993, Las Vegas, NV.

IT Corporation, 1993b. Well UE-10j Completion, Testing, and Sampling Criteria, Revision 2, September 29, 1993, Las Vegas, NV.

IT Corporation, 1993c. "UE-10j Wellsite Logbook (Testing)", from March to November 1993, Las Vegas, NV.

IT Corporation, 1993d. Notes from M. O'Hagan, 1993, on Caliper Log by Atlas Wireline Services, October 27, 1993, Las Vegas, NV. 
IT Corporation, 1995. Pre-completion Hydrologic Testing Documentation Package for Well UE-10j, Las Vegas, NV.

Lyles, B. F., 1993. Increased Thermal-Pulse Flowmeter Resolution by Adding a Packer and Computer, Desert Research Institute Report, September 16, Reno, NV.

McArthur, R., 1979. Lithologic Log of UE-10j, Memorandum to Nancy Howard, Lawrence Livermore National Laboratory, November 8, Mercury, NV.

Raytheon Services Nevada, 1992. Re-Completion Plan for GCP UE-10j, November 18, 1992, Drilling Program Number D-009-001, Las Vegas, NV.

Raytheon Services Nevada, 1993a. Re-Completion Program for UGTA RI/FS Well UE-10j, Revision 1, October 14, 1993, Drilling Program Number D-010-001, Las Vegas, NV.

Raytheon Services Nevada, 1993b. Summary Estimate Number 3753-510, November 16, 1992, Las Vegas, NV.

Raytheon Services Nevada, 1993c. Summary Estimate Number 3753-510C, March 17, 1993, Las Vegas, NV.

RSN, see Raytheon Services Nevada.

Winograd, I. J. and W. Thordarson, 1975. Hydrogeologic and Hydrochemical Framework, South-Central Great Basin, Nevada-California, with Special Reference to the Nevada Test Site, U.S. Geological Survey Professional Paper 712-C, Washington, D.C. 


\section{Appendix A Drilling Data}

\footnotetext{
A-1 List of Records of Verbal Communication for Well UE-10j

A-2 Drilling Parameter Logs for Well UE-10j

A-3 Casing and Tubing Data for Well UE-10j

A-4 Well UE-10j Drilling Fluids, Additives, and Cement Composition
} 

Appendix A-1

List of Records of Verbal Communication for Well UE-10j 



\section{A-1 \\ List of Records of Verbal Communication for Well UE-10j \\ (Page 1 of 2)}

\begin{tabular}{|c|c|c|}
\hline RVC\# & Date & Subject \\
\hline RVC-0259 & $01 / 11 / 1993$ & UE-10j Program Change (Item \#6) \\
\hline RVC-0267 & 02/16/1993 & UE-10j Depth Check Run \\
\hline RVC-0269 & 02/04/1993 & UE-10j Drilling Fluids \\
\hline RVC-0270 & 02/03/1993 & UE-10j Program Change (Item \#8) \\
\hline RVC-0271 & 02/10/1993 & UE-10j Additional Reserve Pit Requirement \\
\hline RVC-0272 & 02/19/1993 & $\begin{array}{l}\text { Revision to Drilling Program for GCP Well UE-10j: Liner } \\
\text { Tear }\end{array}$ \\
\hline RVC-0273 & 02/22/1993 & UE-10j Re-Completion Plan - Item \#10 Change \\
\hline RVC-0274 & 02/23/1993 & UE-10j Drilling Plan \\
\hline RVC-0275 & 02/23/1993 & UE-10j Logging Requirement \\
\hline RVC-0277 & 02/25/1993 & UE-10j Re-Completion Program Changes \\
\hline RVC-0285 & 03/18/1993 & UE-10j Pump Requirement \\
\hline RVC-0291 & 04/06/1993 & UE-10j Program Change \\
\hline RVC-0294 & 04/13/1993 & $\begin{array}{l}\text { Revise Re-Completion Program, Rev. 3, for GCP Well } \\
\text { UE-10j (Omit Step Drawdown Test) }\end{array}$ \\
\hline RVC-0297 & 04/14/1993 & $\begin{array}{l}\text { Re-Completion GCP Well UE-10j: Temperature Log } \\
\text { Added }\end{array}$ \\
\hline RVC-0300 & 04/29/1993 & UE-10j Program Change \\
\hline RVC-0333 & 09/29/1993 & UE-10j Cement Ports Modification (TAM) \\
\hline RVC-0334 & $10 / 12 / 1993$ & UE-10j Completion Equipment \\
\hline RVC-0336 & $10 / 27 / 1993$ & UE-10j Completion Requirements \\
\hline RVC-0337 & $11 / 01 / 1993$ & UE-10j Delete and Add Re-Completion Hardware \\
\hline RVC-0338 & $11 / 03 / 1993$ & UE-10j Banding 4-1/2" to 5-1/2" Hardware \\
\hline RVC-0339 & $11 / 09 / 1993$ & UE-10j Fluid Density Log Requirements \\
\hline RVC-0340 & $11 / 15 / 1993$ & UE-10j Borehole TV Camera Requirement \\
\hline RVC-0341 & $11 / 17 / 1993$ & UE-10j Fluid Sample Requirement \\
\hline RVC-0342 & $11 / 17 / 1993$ & UE-10j Bridge Plug Requirement \\
\hline RVC-0343 & $11 / 17 / 1993$ & UE-10j Circulating and Swabbing Requirement \\
\hline L-93-009 & 02/03/1993 & TAM Truck Operation by RSN \\
\hline
\end{tabular}




\section{A-1}

List of Records of Verbal Communication for Well UE-10j

(Page 2 of 2)

\begin{tabular}{||c|c|l||}
\hline RVC\# & Date & \multicolumn{1}{c|}{ Subject } \\
\hline \hline L-93-014 & $03 / 16 / 1993$ & Barbour Corp. Camera Surveys \\
\hline L-93-015 & $03 / 02 / 1993$ & Logging in GCP Well UE-10j \\
\hline L-93-031 & $06 / 22 / 1993$ & Equipment for TAM Truck \\
\hline L-93-034 & $07 / 07 / 1993$ & FY Costs for TAM Truck \\
\hline L-93-045 & $11 / 03 / 1993$ & Oil for Use in TAM Shifting Tool \\
\hline
\end{tabular}


Appendix A-2

\section{Drilling Parameter Logs for Well UE-10j}





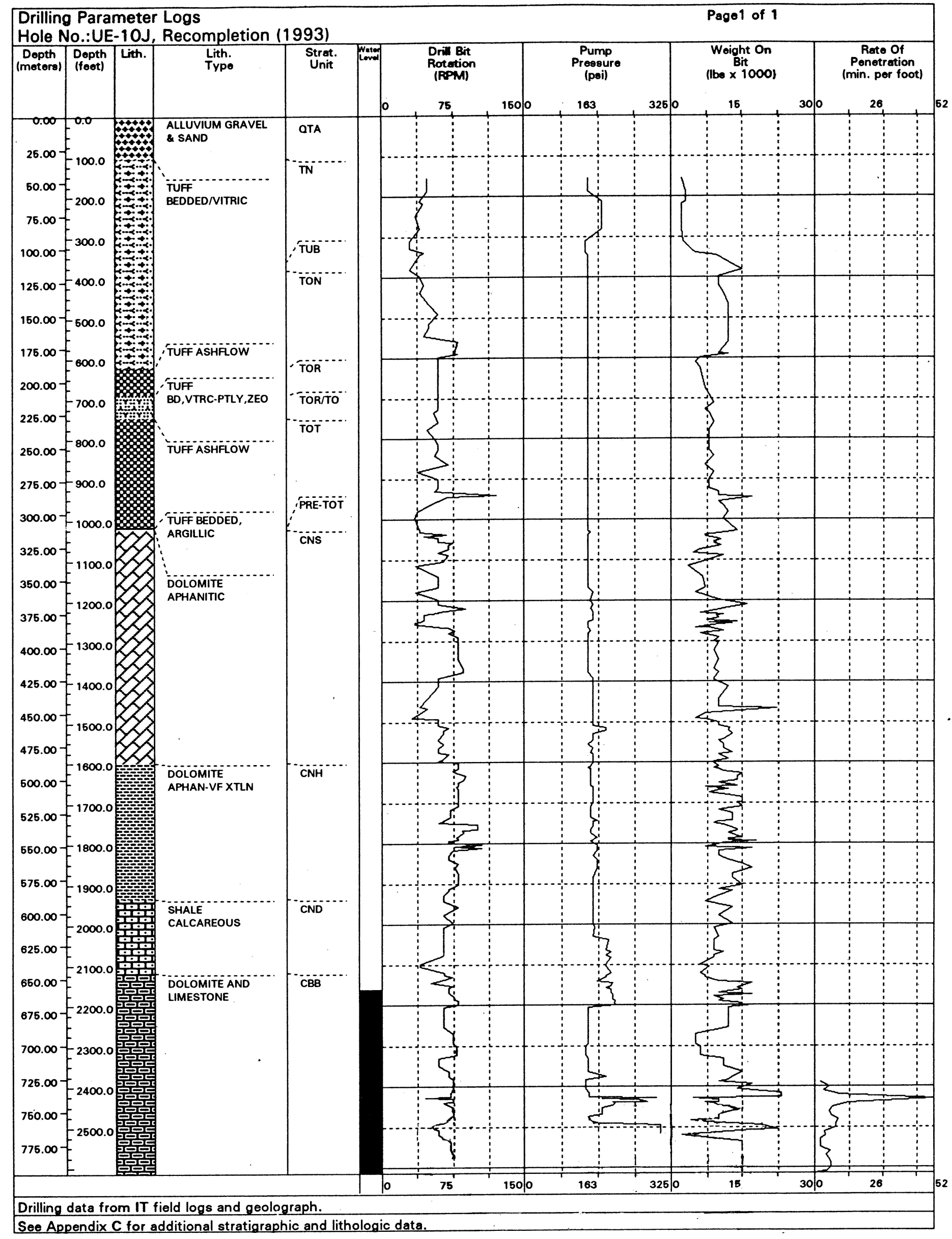


This page intentionally left blank.

A-2-2 


\section{Appendix A-3}

\section{Casing and Tubing Data for Well UE-10j}



A-3

Casing and Tubing Data for Well UE-10j

\begin{tabular}{|c|c|c|c|c|c|c|c|}
\hline CASING & $\begin{array}{c}\text { Depth Interval } \\
\text { meters } \\
\text { (feet) }\end{array}$ & Type & Grade & $\begin{array}{c}\text { Outside } \\
\text { Diameter } \\
\text { inches }\end{array}$ & $\begin{array}{c}\text { Inside } \\
\text { Diameter } \\
\text { centimeters } \\
\text { (inches) } \\
\end{array}$ & $\begin{array}{c}\text { Wall } \\
\text { Thickness } \\
\text { centimeters } \\
\text { (inches) }\end{array}$ & $\begin{array}{c}\text { Weight } \\
\text { per foot } \\
\text { (pound/foot) }\end{array}$ \\
\hline Surface Casing & $\begin{array}{l}0 \text { to } 16.8 \\
\text { (0 to } 55)\end{array}$ & $\begin{array}{c}\text { Carbon } \\
\text { Steel }\end{array}$ & K-55 & 20 & $\begin{array}{c}49.5 \\
(19.5)\end{array}$ & $\begin{array}{c}0.64 \\
0.250\end{array}$ & 52.73 \\
\hline $\begin{array}{l}\text { Intermediate } \\
\text { Casing }\end{array}$ & $\begin{array}{l}0 \text { to } 670.0 \\
\text { (0 to } 2,198)\end{array}$ & $\begin{array}{c}\text { Carbon } \\
\text { Steel }\end{array}$ & K-55 & $13 d$ & $\begin{array}{c}40.4 \\
(12.615)\end{array}$ & $\begin{array}{c}1.93 \\
(0.760)\end{array}$ & 54.5 \\
\hline \multicolumn{8}{|l|}{$\begin{array}{l}\text { COMPLETION } \\
\text { STRINGS }\end{array}$} \\
\hline String \#1 & $\begin{array}{c}0 \text { to } 627.9 \\
(0 \text { to } 2,059.9)\end{array}$ & $\begin{array}{c}\text { Carbon } \\
\text { Steel }\end{array}$ & P110 & $51 / 2$ & $\begin{array}{c}12.1 \\
(4.778)\end{array}$ & $\begin{array}{c}0.92 \\
(0.361)\end{array}$ & 20.0 \\
\hline $\begin{array}{c}\text { String \#1 } \\
\text { (with sliding } \\
\text { sleeves) }\end{array}$ & $\begin{array}{c}627.9 \text { to } 773.0 \\
(2,059.9 \text { to } \\
2,536.1)\end{array}$ & $\begin{array}{l}\text { Stainless } \\
\text { Steel }\end{array}$ & $\begin{array}{c}\text { Schedule } 40 \\
\text { T304L }\end{array}$ & $51 / 2$ & $\begin{array}{c}12.8 \\
(5.05)\end{array}$ & $\begin{array}{c}0.64 \\
(0.25)\end{array}$ & 14.6 \\
\hline $\begin{array}{c}\text { String \#2 } \\
\text { (pump riser) }\end{array}$ & $\begin{array}{c}0 \text { to } 602.6 \\
(0 \text { to } 1,976.9)\end{array}$ & $\begin{array}{c}\text { Carbon } \\
\text { Steel }\end{array}$ & N80 & $4 \frac{1}{2}$ & $\begin{array}{l}10.2 \\
(4.0)\end{array}$ & $\begin{array}{c}0.64 \\
(0.25)\end{array}$ & 11.6 \\
\hline $\begin{array}{c}\text { String \#2 } \\
\text { (pump riser) }\end{array}$ & $\begin{array}{c}602.6 \text { to } 665.0 \\
(1,976.9 \text { to } \\
2,181.9)\end{array}$ & $\begin{array}{l}\text { Stainless } \\
\text { Steel }\end{array}$ & $\begin{array}{c}\text { Schedule } 40 \\
\text { T304L }\end{array}$ & $4 \frac{1}{2}$ & $\begin{array}{c}10.2 \\
(4.0) \\
\text { nominal }\end{array}$ & $\begin{array}{c}0.64 \\
(0.25)\end{array}$ & 10.8 \\
\hline
\end{tabular}


This page intentionally left blank.

A-3-2 


\section{Appendix A-4}

\section{Well UE-10j Drilling Fluids, Additives, and Cement Composition}





\section{A-4}

Well UE-10j Drilling Fluids, Additives, and Cement Composition

\begin{tabular}{|c|c|}
\hline $\begin{array}{c}\text { \#3 Davis Mix } \\
\text { (Air Foam) }\end{array}$ & Cement Composition \\
\hline $0.22 \mathrm{~m}^{3 \mathrm{a}}\left(58 \mathrm{gal}^{\mathrm{b}}\right)$ detergent & \\
$907 \mathrm{~kg}^{\mathrm{c}}\left(2,000 \mathrm{lb}^{\mathrm{d}}\right)$ bentonite & Type II Portland cement with three \\
$110 \mathrm{~kg}(50 \mathrm{lb})$ guar gum & percent calcium chloride \\
$220 \mathrm{~kg}(100 \mathrm{lb})$ soda ash & \\
\hline
\end{tabular}
a cubic meters
b gallons
c kilograms
d pounds

NOTES:

1. Drilling fluid mixes consist of 19.1 cubic meters (120 barrels per load).

2. A concentrated solution of lithium bromide was added to all introduced fluids to make up a final concentration of 20 to 40 milligrams per liter. 
This page intentionally left blank.

A-4-2 


\section{Appendix B}

Fluid Management Data 

Marcin 1. 1994

Project No.: 301957.433 .01

Mr. Steven Lawrence

Project Manager. UGTA Operable Unit

U.S. Department of Energy

Nevada Operations Office

Post Office Box 98518

Las Vegas. Nevada 39193-8518

Contract No. DE-AC08-92NV10972

Well Ue-10i Fluid Management Status

Aquifer Testing/Initial Well Installation

Dear Mr. Lawrence:

The enclosed information is submitted for your review in accordance with the reporting requirements outlined in the Fluid Management Plan for Nevada Environmental Restoration Project. Final data (see attached) from well effluent samples collected from Underground Test Area (UGTA) Operable Unit Monitoring Well Ue-10j indicate that all fluid quality objectives have been met. The attached Fluid Management Reporting Form summarizes fluid production totals and disposition status. Analytical data indicate that all industrial wastes remaining in the lined sumps are non-hazardous and within the fluid quality objectives established for well construction activities. Remaining activities include multiple zone development and aquifer characterization sampling.

All data supporting this fluid status report are available for your review upon request. If you have any questions. please contact Linda Cardenas at 794-1700.

Sincerely,

IT CORPORATION

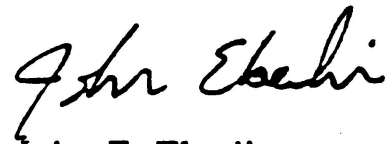

John E. Eberlin

Project Manager

JEE:LAC:bla

LV19400391cipps

Regional Otfice

4330 South Valley View. Suite 114 • Las Vegas. Nevada 89103-4047 • 702-794-1700

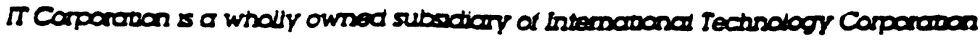

B-1 
This page intentionally left blank.

B-2 


\section{ER FLUID MANAGEMENT REPORTING FORM}

Site Identification: Ue-10j

Site Location:

Area 10 - NTS

Site Coordinates: N 887,033/E 670,453

Well Classification: Recompletion Monitoring Well

IT Project No:
Report Date:

DOE/NV Project Manager:

IT Project Manager:

IT Site Representative:

IT Waste Coordinator:
03/01/94

S. Lawrence

J. Eberlin

M. O'Hagan

L. Cardenas, $\not$ ice

\begin{tabular}{|c|c|c|c|c|c|c|c|c|c|c|c|c|}
\hline \multirow{2}{*}{$\begin{array}{l}\text { Well Construction } \\
\text { Activity }\end{array}$} & \multicolumn{2}{|c|}{ Activity Duration } & \multirow{2}{*}{$\begin{array}{l}\text { \#Ops. } \\
\text { Days } \\
\text { (A) }\end{array}$} & \multirow{2}{*}{$\begin{array}{l}\text { Well } \\
\text { Depth } \\
\text { (m) }\end{array}$} & \multirow{2}{*}{$\begin{array}{l}\text { Import } \\
\text { Fluid } \\
\text { (m') }\end{array}$} & \multicolumn{2}{|c|}{ I Lined sump 1 (m) } & \multicolumn{2}{|c|}{ Uned Sump $2(\mathrm{~m})$} & \multirow{2}{*}{$\frac{\begin{array}{c}\text { [nfiltration } \\
\text { Area }\left(m^{3}\right)\end{array}}{\text { Liquids }}$} & \multirow[t]{2}{*}{$\begin{array}{l}\text { Other } \\
\text { (C) }\end{array}$} & \multirow{2}{*}{$\begin{array}{c}\text { Fluid } \\
\text { Quality } \\
\text { Objectives } \\
\text { Met? }\end{array}$} \\
\hline & From & To & & & & $\begin{array}{l}\text { Solids } \\
\text { (B) }\end{array}$ & Liquids & Solids & Liquids & & & \\
\hline $\begin{array}{l}\text { Stage I: } \\
\text { Vadose-Zone Drilling }\end{array}$ & $02 / 01 / 93$ & $02 / 11 / 93$ & 9 & 658.7 & 414 & 71 & 1433 & 160 (D) & 640 (D) & $-0-$ & -0 & YES \\
\hline $\begin{array}{l}\text { Stage II: } \\
\text { Saturated-Zone Drilling }\end{array}$ & $02 / 22 / 93$ & $02 / 24 / 93$ & 4 & 796.8 & 318 & $<2(E)$ & $80(E)$ & $-0-$ & -0 & -0 & -0 & YES \\
\hline $\begin{array}{l}\text { Stage III: } \\
\text { Initial Well } \\
\text { Development }\end{array}$ & $02 / 26 / 93$ & $04 / 20 / 93$ & 6 & 796.8 & -0 & $<2$ & 633 & -0 & -0 & -0 & -0 & YES \\
\hline $\begin{array}{l}\text { Stage IV: } \\
\text { Aquifer Testing }\end{array}$ & $\begin{array}{l}04 / 27 / 93 \\
10 / 19 / 93 \\
\end{array}$ & $\begin{array}{l}04 / 30 / 93 \\
10 / 26 / 93 \\
\end{array}$ & $\begin{array}{c}3 \\
2.5\end{array}$ & 796.8 & $\begin{array}{l}-0 \\
-0 \\
\end{array}$ & $\begin{array}{l}-0- \\
-0- \\
\end{array}$ & $\begin{array}{c}818 \\
2105 \\
\end{array}$ & $\begin{array}{l}-0- \\
-0\end{array}$ & $\begin{array}{l}-0 \\
-0\end{array}$ & $\begin{array}{c}6662 \\
-0- \\
\end{array}$ & $\begin{array}{l}-0 \\
-0\end{array}$ & $\begin{array}{l}\text { YES } \\
\text { YES }\end{array}$ \\
\hline $\begin{array}{l}\text { Stage V: } \\
\text { Well Completion/No } \\
\text { Final Development }\end{array}$ & $11 / 09 / 93$ & $11 / 17 / 93$ & 6 & 796.8 & 207 & -0. & -0 & -0 & -0 & $-0-$ & -0 & YES \\
\hline \multicolumn{3}{|c|}{ Cumulative Production Totals to Date: } & 30.5 & 796.8 & 939 & 71 & 5069 & 160 & 640 & 6662 & -0 & YES \\
\hline
\end{tabular}

(A) Operational days refer to the number of days that the drill rig or, during aquifer tresting, that the pump was in operation during at least part of one shift.

(B) Solids refer to the drill volume estimates include added volume attributed to interstitial spaces.

(C) "Other" refers to fluid conveyance to other bcations or facilities away from the well site, such as vacuum truck transport to another location

(D) Approximately $800 \mathrm{~m}^{3}$ of liquids and solids and transferred from Lined Sump \#1 to Lined Sump \#2 to create additional freeboard.

(E) Lost circulation while drilling on $02 / 22 / 93$ at 737.6 meters; minimum return of solids and liquids thereafter.

$m=$ meters; $m^{3}=$ cubic meters

Total Sump Capacity: Lined Sump \#1 = $2000 \mathrm{~m}^{3} \quad$ Lined Sump \#2 $=1030 \mathrm{~m}^{3}$

Remaining Sump Capacity (Approximate) as of 11/17/93: Sump \#1 = $1000 \mathrm{~m}^{3} \quad(50 \%) \quad$ Sump \#2=824 $\mathrm{m}^{3}$ (80\%)

IT Authorizing Signature/Date: 
Anions \& Additional Analytes

\begin{tabular}{|c|c|c|c|c|c|c|}
\hline Param & & & & & $\mathbf{F}$ & $\mathrm{pH}$ \\
\hline Fluid Qu & bjectives & $\mathrm{ng} / \mathrm{L})$ & & & 20 & NA \\
\hline Site & Date & Sample ID & Type* & Matrix & & \\
\hline UE-10j & $02 / 02 / 93$ & GCP00067 & FMS-DL & Fluid & - & - \\
\hline UE-10j & $02 / 02 / 93$ & GCP00068 & FMS-DL & Fluid & 0.7 & 8.7 \\
\hline UE-10j & $02 / 26 / 93$ & GCP00089 & FMS-DL & GW & 0.247 & 8.19 \\
\hline UE-10j & $04 / 14 / 93$ & GCP00115 & FMS-DL & GW & 0.375 & 6.93 \\
\hline UE-10j & $04 / 14 / 93$ & GCP00115D & FMS-DL & GW & 0.383 & 6.95 \\
\hline UE-10j & $04 / 28 / 93$ & GCP00129 & FMS-DL & GW & 0.38 & 7.33 \\
\hline UE-10j & $04 / 28 / 93$ & GCP00129b & FMS-DL & GW & 0.38 & 7.24 \\
\hline UE-10j & $10 / 14 / 93$ & GCP00184 & FMS-DL & GW & 0.3 & 7.3 \\
\hline UE-10j & $10 / 20 / 93$ & GCP00185 & FMS-DL & GW & - & 6.80 \\
\hline UE-10j & $10 / 25 / 93$ & GCP00186 & FMS-DL & GW & - & 6.65 \\
\hline UE-10j & $02 / 05 / 93$ & GCP00074 & FMS-SP & Fluid & 0.8 & 8.3 \\
\hline UE-10j & $02 / 08 / 93$ & GCP00076 & FMS-SP & Fluid & 0.6 & 8.1 \\
\hline UE-10j & 02/10/93 & GCP00083 & FMS-SP & Fluid & $<0.5$ & 8.3 \\
\hline UE-10j & $02 / 11 / 93$ & GCP00084 & FMS-SP & Fluid & 0.5 & 8.1 \\
\hline UE-10j & $02 / 12 / 93$ & GCP00085 & FMS-SP & Fluid & 0.6 & 8.1 \\
\hline & & & & & & \\
\hline UE-10j & $02 / 02 / 93$ & GCP00069 & QCS-BT & Water & 1.2 & 7.9 \\
\hline UE-10j & $02 / 03 / 93$ & GCP00070 & QCS-BT & Fluid & 1.1 & 9.1 \\
\hline$U E-10 j$ & $02 / 16 / 93$ & GCP00086 & QCS-BT & Water & 1.1 & 8.1 \\
\hline & & 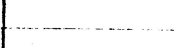 & & & & \\
\hline$J E-10 j$ & $02 / 04 / 93$ & GCP00075 & QCS-FR & Water & $<0.5$ & 7.2 \\
\hline$J E-10 j$ & $04 / 28 / 93$ & GCP00130 & QCS-FR & Water & ND & 4.76 \\
\hline
\end{tabular}


Total Metals

\begin{tabular}{|c|c|c|c|c|c|c|c|c|c|c|c|c|}
\hline \multicolumn{5}{|c|}{ Parameter } & As & $\mathbf{B a}$ & Cd & $\mathrm{Cr}$ & $\mathrm{Cu}$ & $\mathrm{Hg}$ & $\mathbf{P b}$ & $\mathrm{Se}$ \\
\hline \multicolumn{5}{|c|}{ Fluid Quality Objectives (mg/L) } & \multirow[t]{2}{*}{0.5} & \multirow[t]{2}{*}{10} & \multirow[t]{2}{*}{0.1} & \multirow[t]{2}{*}{0.5} & \multirow[t]{2}{*}{10} & \multirow[t]{2}{*}{ NA } & \multirow[t]{2}{*}{0.5} & \multirow[t]{2}{*}{0.1} \\
\hline Site & Date & Sample ID & Type* & Matrix & & & & & & & & \\
\hline UE-10j & $02 / 02 / 93$ & GCP00067 & FMS-DL & Fluid & 0.30 & 11 & 0.29 & 1.4 & 1.1 & 0.0037 & 2.2 & $<0.025$ \\
\hline UE-10j & $02 / 02 / 93$ & GCP00068 & FMS-DL & Fluid & 0.025 & 0.35 & $<0.025$ & 0.045 & 0.045 & $<0.0001$ & 0.085 & $<0.025$ \\
\hline UE-10j & $02 / 26 / 93$ & GCP00089 & FMS-DL & GW & ND & 0.082 & ND & ND & 0.136 & ND & 0.026 & ND \\
\hline UE-10j & $04 / 14 / 93$ & GCP00115 & FMS-DL & GW & ND & 0.147 & ND & ND & - & ND & 0.008 & ND \\
\hline UE-10j & $04 / 14 / 93$ & GCP00115D & FMS-DL & GW & ND & 0.157 & ND & ND & - & ND & 0.009 & ND \\
\hline UE-10] & $04 / 28 / 93$ & GCP00129 & FMS-DL & GW & 0.003 & 0.149 & ND & ND & ND & ND & 0.003 & ND \\
\hline UE-10j & $04 / 28 / 93$ & GCP00129b & FMS-DL & GW & 0.004 & 0.145 & ND & ND & - & ND & 0.007 & ND \\
\hline UE-10j & $10 / 14 / 93$ & GCP00184T & FMS-DL & GW & 0.0025 & 0.10 & $<0.00011$ & ND & 0.013 & & 0.011 & $<0.0014$ \\
\hline UE-10j & $10 / 14 / 93$ & GCP00184D & FMS-DL & GW & 0.0015 & 0.098 & 0.00023 & ND & $<0.016$ & & $<0.0012$ & $<0.0014$ \\
\hline UE-10j & $10 / 20 / 93$ & GCP00185T & FMS-DL & GW & 0.002 & 0.11 & ND & ND & $\therefore$ & ND & 0.002 & 0.0014 \\
\hline UE-10j & $10 / 20 / 93$ & GCP00185D & FMS-DL & GW & 0.0003 & 0.0004 & 0.003 & 0.007 & $<0.016$ & 0.0001 & 0.0004 & 0.0004 \\
\hline UE-10i & $10 / 25 / 93$ & GCP00186 & FMS-DL & GW & ND & $<0.006$ & ND & ND & 0.014 & ND & $<0.001$ & $<0.002$ \\
\hline \multirow[t]{2}{*}{ UE-10j } & $11 / 08 / 93$ & GCP00187 & FMS-DL & GW & 0.001 & 0.012 & ND & ND & 0.012 & ND & 0.002 & 0.001 \\
\hline & & & . & & & & & & & & & \\
\hline UE-10j & $02 / 05 / 93$ & GCPO00074 & FMS-SP & Fluid & 0.014 & 0.16 & $<0.005$ & 0.008 & 0.021 & $<0.0001$ & 0.036 & $\leq 0.005$ \\
\hline UE-10j & $02 / 08 / 93$ & GCP00076 & FMS-SP & Fluid & 0.006 & 0.08 & $<0.005$ & 0.008 & 0.021 & $<0.001$ & 0.007 & $<0.005$ \\
\hline UE-10j & $02 / 10 / 93$ & GCPO0083 & FMS-SP & Fluid & 0.011 & 0.28 & $\leq 0.005$ & 0.021 & 0.025 & $<0.001$ & 0.036 & $<0.005$ \\
\hline UE-10j & $02 / 11 / 93$ & GCP00084 & FMS-SP & Fluid & 0.017 & 0.20 & $<0.005$ & 0.016 & 0.023 & $<0.001$ & 0.027 & $<0.005$ \\
\hline UE-10j & $02 / 12 / 93$ & GCP00085 & FMS-SP & Fluid & 0.008 & 0.27 & $<0.005$ & 0.015 & 0.024 & $<0.001$ & 0.028 & $<0.005$ \\
\hline UE-10j & $02 / 02 / 93$ & GCP00069 & QCS-BT & Water & $<0.005$ & $<0.05$ & $<0.005$ & $<0.005$ & 0.013 & $<0.0001$ & $<0.005$ & $<0.005$ \\
\hline UE-10] & $02 / 03 / 93$ & GCP00070 & QCS-BT & Fluid & 0.12 & 8.5 & 0.055 & $<0.025$ & 0.055 & $<0.001$ & 0.80 & $<0.25$ \\
\hline \multirow[t]{2}{*}{ UE-10j } & $02 / 16 / 93$ & GCP00086 & QCS-BT & Water & 0.006 & $<0.05$ & $<0.005$ & $<0.005$ & 0.005 & $<0.0001$ & 0.005 & $<0.005$ \\
\hline & & & & & & & & & & & & $\cdot$ \\
\hline UE-10j & $02 / 04 / 93$ & GCP00075 & QCS-FR & Water & $<0.005$ & $<0.05$ & $<0.005$ & $<0.005$ & 0.074 & $<0.0001$ & $<0.005$ & $<0.005$ \\
\hline UE-10j & $04 / 28 / 93$ & GCP00130 & QCS-FR & Water & ND & ND & ND & ND & ND & ND & ND & ND \\
\hline
\end{tabular}

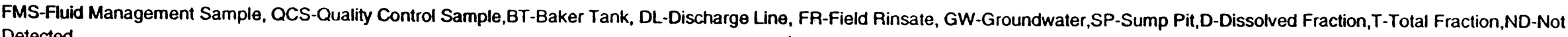




\begin{tabular}{|c|c|c|c|c|c|c|}
\hline \multicolumn{5}{|c|}{ Parameter } & \multirow{3}{*}{$\frac{\mathrm{Ag}}{0.5}$} & \multirow{3}{*}{$\begin{array}{l}\mathrm{Zn} \\
50\end{array}$} \\
\hline \multicolumn{5}{|c|}{ Fluid Quality Objectives ( $\mathrm{mg} / \mathrm{L}$ ) } & & \\
\hline Site & Date & Sample ID & Type* & Matrix & & \\
\hline UE-10j & $02 / 02 / 93$ & GCP00067 & FMS-DL & Fluid & $<0.025$ & 4.6 \\
\hline UE-10j & $02 / 02 / 93$ & GCP00068 & FMS-DL & Fluid & $<0.025$ & 0.22 \\
\hline UE-10j & $02 / 26 / 93$ & GCP00089 & FMS-DL & GW & ND & 0.136 \\
\hline UE-10j & $04 / 14 / 93$ & GCP00115 & FMS-DL & GW & ND & - \\
\hline UE-10j & $04 / 14 / 93$ & GCP00115D & FMS-DL & GW & ND & - \\
\hline UE-10j & $04 / 28 / 93$ & GCP00129 & FMS-DL & GW & ND & ND \\
\hline UE-10j & $04 / 28 / 93$ & GCP00129b & FMS-DL & GW & ND & - \\
\hline UE-10j & 10/14/93 & GCP00184T & FMS-DL & GW & ND & 0.024 \\
\hline UE-10j & $10 / 14 / 93$ & GCP00184D & FMS-DL & GW & ND & $<0.007$ \\
\hline$U E-10 j$ & $10 / 20 / 93$ & GCP00185T & FMS-DL & GW & ND & - \\
\hline UE-10j & $10 / 20 / 93$ & GCP00185D & FMS-DL & GW & 0.003 & 0.017 \\
\hline UE-10i & $10 / 25 / 93$ & GCP00186 & FMS-DL & GW & ND & 0.019 \\
\hline UE-10i & $11 / 08 / 93$ & GCP00187 & FMS-DL & GW & ND & $<0.005$ \\
\hline$U E-10 j$ & $02 / 05 / 93$ & GCP00074 & FMS-SP & Fluid & $<0.005$ & 0.11 \\
\hline$U E-10 j$ & $02 / 08 / 93$ & GCP00076 & FMS-SP & Fluid & $<0.005$ & 0.025 \\
\hline$U E-10 j$ & $02 / 10 / 93$ & GCP00083 & FMS-SP & Fluid & $<0.005$ & 0.071 \\
\hline$U E-10 j$ & $02 / 11 / 93$ & GCP00084 & FMS-SP & Fluid & $\leq 0.005$ & 0.088 \\
\hline UE-10j & $02 / 12 / 93$ & GCP00085 & FMS-SP & Fluid & $<0.005$ & 0.078 \\
\hline UE-10i & $02 / 02 / 93$ & GCP00069 & QCS-BT & Water & $<0.005$ & 0.018 \\
\hline UE-10j & $02 / 03 / 93$ & GCP00070 & QCS-BT & Fluid & $<0.025$ & 0.81 \\
\hline UE-10j. & $02 / 16 / 93$ & GCP00086 & QCS-BT & Water & $<0.005$ & $<0.005$ \\
\hline UE-10j & $02 / 04 / 93$ & GCP00075 & QCS-FR & Water & $<0.005$ & 0.13 \\
\hline UE-10i & $04 / 28 / 93$ & GCP00130 & QCS-FR & Whater & ND & ND \\
\hline
\end{tabular}


Radiation Chemistry

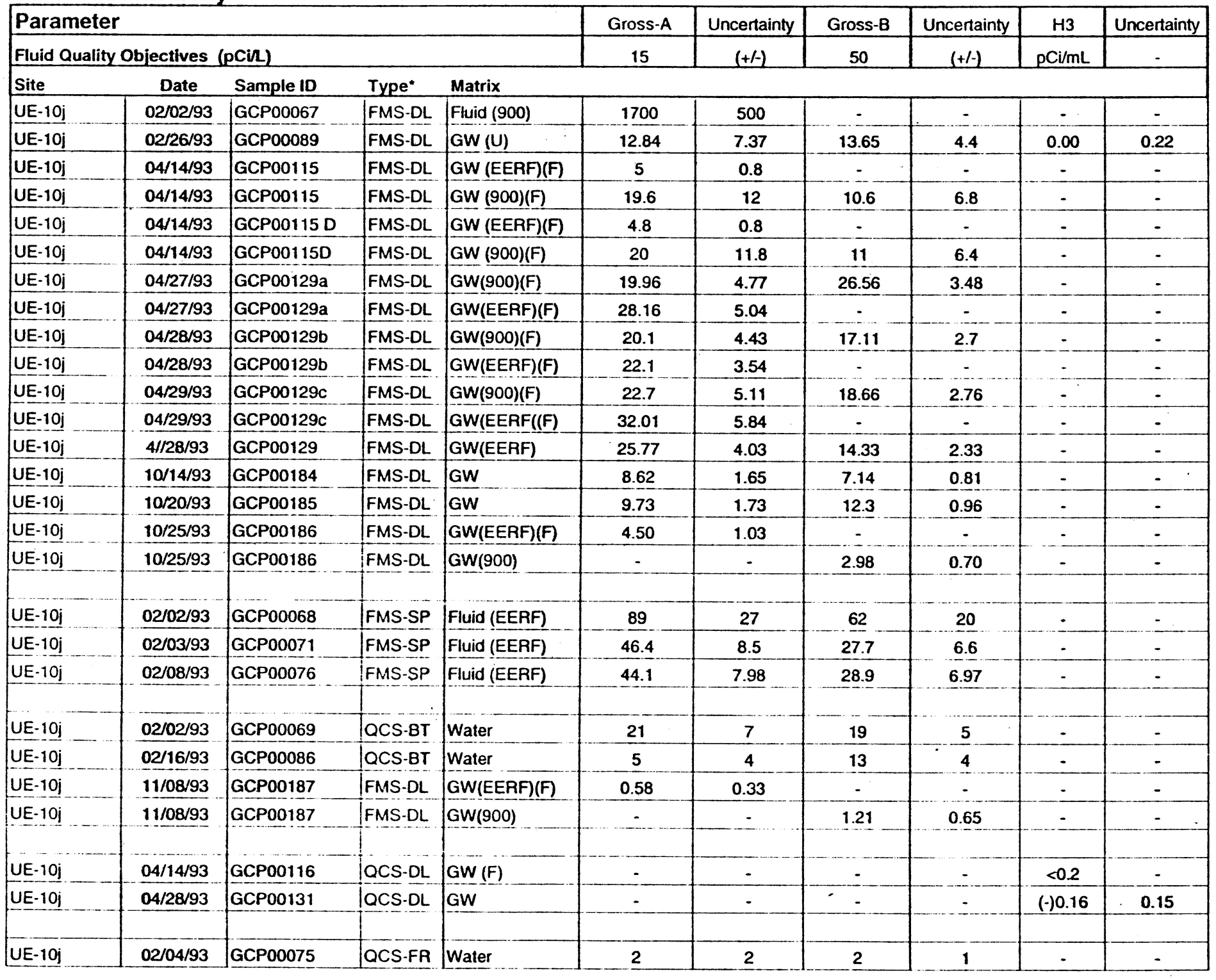


Radiation Chemistry

\begin{tabular}{|c|c|c|c|c|c|c|c|c|c|c|}
\hline \multicolumn{5}{|c|}{ Parameter } & Gross-A & Uncertainty & Gross-B & Uncertainty & H3 & Uncertainty \\
\hline \multicolumn{5}{|c|}{ Fluid Quality Objectives (pCin) } & 15 & $(+1-)$ & 50 & $(+1-)$ & $\mathrm{pCi} / \mathrm{mL}$ & - \\
\hline Site & Date & Sample ID & Type* & Matrix & & & & & & \\
\hline UE-10j & $04 / 28 / 93$ & GCP00130 & QCS-FR & Water & 0.48 & 0.59 & $(-) 0.46$ & 1.96 & - & - \\
\hline
\end{tabular}




\section{Appendix C}

Stratigraphic and Lithologic Logs 

Stratigraphic Log of Well UE-10j.

(Compiled by Lance Prothro, Raytheon Services Nevada, 14 August 1995)

\begin{tabular}{|c|c|c|c|c|c|c|}
\hline \multicolumn{2}{|c|}{ Depth } & \multirow[b]{2}{*}{ Lithology } & \multirow[b]{2}{*}{ Stratigraphic Unit } & \multirow[b]{2}{*}{ Symbol } & \multicolumn{2}{|c|}{ Thickness } \\
\hline Meters & Feet & & & & Meters & Feet \\
\hline $0-32$ & $0-106$ & $\begin{array}{l}\text { Sandy Gravel: Gravel } \\
\text { and cobble beds in a } \\
\text { sand and silt matrix. }\end{array}$ & Alluvium & QTa & 32 & 106 \\
\hline $32-109$ & $106-358$ & $\begin{array}{l}\text { Bedded Tuff: Vitric, } \\
\text { partially argillic. }\end{array}$ & $\begin{array}{l}\text { Tunnel Formation, } \\
\text { undifferentiated }\end{array}$ & $\mathrm{Tn}$ & 77 & 252 \\
\hline $109-116$ & $358-381$ & Bedded Tuff: Vitric. & $\begin{array}{l}\text { Tub Spring Tuff }{ }^{*} \\
\text { Volcanics of Big Dome }\end{array}$ & Tub & 7 & 23 \\
\hline $116-190$ & $381-623$ & $\begin{array}{l}\text { Bedded Tuff: Vitric and } \\
\text { argillic. }\end{array}$ & $\begin{array}{c}\text { tunnel beds } 1 \text { and } 2^{\ddagger} \text {, } \\
\text { undifferentiated, } \\
\text { Volcanics of } \\
\text { Oak Spring Butte }^{\dagger}\end{array}$ & Ton & 74 & 242 \\
\hline $190-210$ & $623-689$ & $\begin{array}{l}\text { Partially Welded Ash- } \\
\text { Flow Tuff: Vitric. }\end{array}$ & $\begin{array}{c}\text { Redrock Valley Tuff }{ }^{*} \text {, } \\
\text { Volcanics of } \\
\text { Oak Spring Butte }\end{array}$ & Tor & 20 & 66 \\
\hline $210-228$ & $689-748$ & $\begin{array}{l}\text { Bedded Tuff: Vitric to } \\
\text { partially zeolitic/argillic. }\end{array}$ & $\begin{array}{l}\text { pre-Redrock Valley Tuff/ } \\
\text { post-tuff of Twin Peaks } \\
\text { bedded tuff, undifferentiated }\end{array}$ & Tor/Tot & 18 & 59 \\
\hline
\end{tabular}


Stratigraphic Log of Well UE-10j (cont.)

\begin{tabular}{|c|c|c|c|c|c|c|}
\hline \multicolumn{2}{|c|}{ Depth } & \multirow[b]{2}{*}{ Lithology } & \multirow[b]{2}{*}{ Stratigraphic Unit } & \multirow[b]{2}{*}{ Symbol } & \multicolumn{2}{|c|}{ Thickness } \\
\hline Meters & Feet & & & & Meters & Feet \\
\hline $228-310$ & $748-1,017$ & $\begin{array}{l}\text { Partially Welded Ash- } \\
\text { Flow Tuff: Devitrified. }\end{array}$ & $\begin{array}{c}\text { tuff of Twin Peaks }{ }^{\ddagger} \text {, } \\
\text { Volcanics of } \\
\text { Oak Spring Butte }\end{array}$ & Tot & 82 & 269 \\
\hline $310-312$ & $1,017-1,024$ & Bedded Tuff: Argillic. & $\begin{array}{l}\text { pre-tuff of Twin Peaks } \\
\text { bedded tuff, undifferentiated }\end{array}$ & pre-Tot & 2 & 7 \\
\hline $312-488$ & $1,024-1,600$ & $\begin{array}{l}\text { Dolomite: Aphanitic to } \\
\text { finely crystalline. }\end{array}$ & $\begin{array}{l}\text { Smoky Member, } \\
\text { Nopah Formation }\end{array}$ & ons & 176 & 576 \\
\hline $488-590$ & $1,600-1,936$ & $\begin{array}{l}\text { Dolomite: Aphanitic to } \\
\text { very finely crystalline, } \\
\text { cherty in part. }\end{array}$ & $\begin{array}{l}\text { Halfpint Member, } \\
\text { Nopah Formation }\end{array}$ & onh & 102 & 336 \\
\hline $590-646$ & $1,936-2,119$ & $\begin{array}{l}\text { Shale: Calcareous, } \\
\text { finely laminated. }\end{array}$ & $\begin{array}{c}\text { Dunderberg Shale Member, } \\
\text { Nopah Formation }\end{array}$ & ond & 56 & 183 \\
\hline $\begin{array}{c}646-796 \\
\text { TD }\end{array}$ & $\begin{array}{c}2,119-2,613 \\
\text { TD }\end{array}$ & $\begin{array}{l}\text { Dolomite and } \\
\text { Limestone: Aphanitic to } \\
\text { very coarsely crystalline. }\end{array}$ & $\begin{array}{l}\text { Banded Mountain Member, } \\
\text { Bonanza King Formation }\end{array}$ & obb & $>150$ & $>494$ \\
\hline
\end{tabular}




\section{Lithologic Log of Well UE-10j}

(Compiled by Lance Prothro, Raytheon Services Nevada, August 14, 1995)

Lithologic descriptions for the interval 0 - $722 \mathrm{~m} \mathrm{(0} \mathrm{-2,370} \mathrm{ft)} \mathrm{are} \mathrm{compiled} \mathrm{from} \mathrm{R.} \mathrm{McArthur} \mathrm{(Lawrence} \mathrm{Livermore} \mathrm{National} \mathrm{Laboratory),}$ November 8, 1979 and USGS Technical Letter: NTS-141 by Ege et al, 1965. Lithologic descriptions below $722 \mathrm{~m}$ (2,370 ft) follow RSN Department Procedure NTS-GEO-003 and were compiled using rotary sidewall core samples and geophysical logs. Stratigraphic contacts and lithologic divisions are tied to geophysical logs whenever possible.

\begin{tabular}{ccc}
\hline $\begin{array}{c}\text { Depth } \\
\text { Meters/(Feet) }\end{array}$ & Lithologic Description & Stratigraphic Unit $^{\star}$ \\
\hline
\end{tabular}

$$
\begin{gathered}
0-32 \mathrm{~m} \\
(0-106 \mathrm{ft})
\end{gathered}
$$

Sandy Gravel: Generally gravel and cobble beds in a sand and silt matrix; gravel and cobble fractions consist of 60 percent moderate-yellowish-brown and pale-red to grayish-purple quartzite, 35 percent medium- to dark-gray argillite, and 5 percent medium-dark-gray limestone and light-gray and light-brown tuff.

Note: Lower contact of interval revised 8/1995 based on reexamination of geophysical logs. Original contact placed at $63 \mathrm{~m}$ (207 ft).

$32-109 m$ $(106-358 \mathrm{ft})$

$109-116 m$ (358 - $381 \mathrm{ft})$

$116-190 \mathrm{~m}$ $(381-623 \mathrm{ft})$

$190-210 m$ $(623-689 \mathrm{ft})$
Bedded Tuff: Generally bedded airfall tuffs and tuffaceous sandstones; generally vitric but partially argillic from 98 - $104 \mathrm{~m}$ (322 - $341 \mathrm{ft})$.

Bedded Tuff: Air-fall tuffs; pumicerich; vitric.

Bedded Tuff: Air-fall tuffs with some tuffaceous sandstones; vitric to $180 \mathrm{~m}$ (591 ft), argillic below.

Partially Welded Ash-Flow Tuff: Vitric.
Alluvium
Tub Spring Tuff

tunnel beds 1 and 2 , undifferentiated 
Lithologic Log of Well UE-10j (cont.)

\begin{tabular}{|c|c|c|}
\hline $\begin{array}{c}\text { Depth } \\
\text { Meters/(Feet) }\end{array}$ & Lithologic Description & Stratigraphic Unit* \\
\hline $\begin{array}{l}210-228 \mathrm{~m} \\
(689-748 \mathrm{ft})\end{array}$ & $\begin{array}{l}\text { Bedded Tuff: Vitric to partially } \\
\text { zeolitic/argillic. }\end{array}$ & $\begin{array}{l}\text { pre-Redrock Valley } \\
\text { Tuff/post-tuff of Twin } \\
\text { Peaks bedded tuff, } \\
\text { undifferentiated }\end{array}$ \\
\hline $\begin{array}{c}228-310 \mathrm{~m} \\
(748-1,017 \mathrm{ft})\end{array}$ & $\begin{array}{l}\text { Partially Welded Ash-Flow Tuff: } \\
\text { Devitrified. }\end{array}$ & tuff of Twin Peaks \\
\hline $\begin{array}{c}310-312 \mathrm{~m} \\
(1,017-1,024 \mathrm{ft})\end{array}$ & Bedded Tuff: Argillized. & $\begin{array}{l}\text { pre-tuff of Twin } \\
\text { Peaks bedded tuff, } \\
\text { undifferentiated }\end{array}$ \\
\hline $\begin{array}{c}312-488 \mathrm{~m} \\
(1,024-1,600 \mathrm{ft})\end{array}$ & $\begin{array}{l}\text { Dolomite: Medium- to medium-dark- } \\
\text { gray; aphanitic to finely crystalline; } \\
\text { brecciated; thick-bedded; stringers of } \\
\text { very-light-gray and pale-grayish- } \\
\text { orange calcite and dolomite; sparse } \\
\text { white to very-light-gray chert nodules. }\end{array}$ & $\begin{array}{l}\text { Smoky Member, } \\
\text { Nopah Formation }\end{array}$ \\
\hline $\begin{array}{c}488-590 \mathrm{~m} \\
(1,600-1,936 \mathrm{ft})\end{array}$ & $\begin{array}{l}\text { Dolomite: Dark-gray; aphanitic to } \\
\text { very finely crystalline; brecciated and } \\
\text { fractured; very thin-bedded with } \\
\text { intercalated laminae of very-light-gray } \\
\text { and pale-grayish-orange to pale-red } \\
\text { silty dolomite and very thin beds of } \\
\text { very-light-gray chert. Between } 572 \\
\text { and } 590 \mathrm{~m} \text { ( } 1,875 \text { and } 1,936 \mathrm{ft}) \\
\text { interbedded dolomite, limestone, and } \\
\text { siltstone grades into the Dunderberg } \\
\text { Shale Member below. }\end{array}$ & $\begin{array}{l}\text { Halfpint Member, } \\
\text { Nopah Formation }\end{array}$ \\
\hline
\end{tabular}




\begin{tabular}{|c|c|c|}
\hline $\begin{array}{c}\text { Depth } \\
\text { Meters/(Feet) }\end{array}$ & Lithologic Description & Stratigraphic Unit* \\
\hline $\begin{array}{c}590-646 \mathrm{~m} \\
(1,936-2,119 \mathrm{ft})\end{array}$ & $\begin{array}{l}\text { Shale: Pale- to dark-reddish-brown; } \\
\text { calcareous; finely laminated; bedding } \\
\text { dips approximately } 40 \text { degrees. } \\
\text { Upper } 9 \mathrm{~m} \text { ( } 30 \mathrm{ft} \text { ) of interval contains } \\
\text { very thin beds of medium-gray and } \\
\text { light-olive-gray limestone; lower } 3 \mathrm{~m} \\
\text { (10 ft) of interval contains beds of } \\
\text { medium-dark-gray limestone. }\end{array}$ & $\begin{array}{c}\text { Dunderberg Shale } \\
\text { Member, } \\
\text { Nopah Formation }\end{array}$ \\
\hline $\begin{array}{c}646-722 \mathrm{~m} \\
(2,119-2,370 \mathrm{ft})\end{array}$ & $\begin{array}{l}\text { Interbedded Dolomite and } \\
\text { Limestone: Dolomite is medium- } \\
\text { light- and medium-dark-gray, } \\
\text { aphanitic to finely crystalline. } \\
\text { Limestone is very-light-gray. Interval } \\
\text { is fractured. }\end{array}$ & $\begin{array}{c}\text { Banded Mountain } \\
\text { Member, } \\
\text { Bonanza King } \\
\text { Formation }\end{array}$ \\
\hline $\begin{array}{c}722-796 \mathrm{~m} \\
(2,370-2,613 \mathrm{ft}) \\
\text { TD }\end{array}$ & $\begin{array}{l}\text { Dolomite: White, yellowish-gray, and } \\
\text { dusky-yellow, mottled; very coarsely } \\
\text { to coarsely crystalline becoming } \\
\text { medium to finely crystalline towards } \\
\text { base of interval; scarce to moderate } \\
\text { grayish-orange and dark-yellowish- } \\
\text { orange staining; trace of inter- } \\
\text { crystalline porosity; geophysical logs } \\
\text { indicate interval is more fractured } \\
\text { than overlying interval. }\end{array}$ & $\begin{array}{c}\text { Banded Mountain } \\
\text { Member, } \\
\text { Bonanza King } \\
\text { Formation }\end{array}$ \\
\hline
\end{tabular}

* Stratigraphic nomenclature for the volcanic section revised August 1995 in accordance with that presented in Ferguson et al., 1994. 


\section{Information on Samples Taken During Drilling of Well UE-10j in 1965}

\section{Sidewall Samples}

The Fenix \& Scisson Hole History states that fifteen samples were taken in the interval 125.0 to $167.6 \mathrm{~m}$ (410 to $550 \mathrm{ft}$ ). Ege, et al. (1965) reports ten samples in this interval, but there is no record that any of these samples were kept.

\section{Conventional Cores}

Ten conventional cores were taken at the intervals listed in Table C-1. The cores are stored at the U.S. Geological Survey Core Library in Mercury, Nevada.

Table C-1

Drilling and Recovery Data for Ten Cores Cut in Well UE-10j in 1965

\begin{tabular}{|c|c|c|c|}
\hline \multirow{2}{*}{ Run Number } & \multirow{2}{*}{$\begin{array}{c}\text { Interval } \\
\text { Meters (feet) }\end{array}$} & \multicolumn{2}{|c|}{ Recovery } \\
\hline & & Meters (feet) & $\begin{array}{c}\text { Percent } \\
\text { Recovered } \\
\end{array}$ \\
\hline 1 & $\begin{array}{c}112.8-115.2 \\
(370.0-378.0)\end{array}$ & $\begin{array}{c}2.4 \\
(8.0)\end{array}$ & 100 \\
\hline 2 & $\begin{array}{l}203.6-206.0 \\
(668.0-676.0)\end{array}$ & $\begin{array}{c}2.4 \\
(8.0)\end{array}$ & 100 \\
\hline 3 & $\begin{array}{c}228.6-231.0 \\
(750.0-758.0)\end{array}$ & $\begin{array}{l}2.4 \\
(8.0)\end{array}$ & 100 \\
\hline 4 & $\begin{array}{c}315.5-316.4 \\
(1,035.0-1,038.0)\end{array}$ & $\begin{array}{c}0.6 \\
(2.0)\end{array}$ & 66.7 \\
\hline 5 & $\begin{array}{c}393.2-394.7 \\
(1,290.0-1,295.0)\end{array}$ & $\begin{array}{c}1.5 \\
(5.0)\end{array}$ & 100 \\
\hline 6 & $\begin{array}{c}493.8-494.7 \\
(1,620.0-1,623.0)\end{array}$ & 0 & 0 \\
\hline 7 & $\begin{array}{c}499.9-501.1 \\
(1,640.0-1,644.0)\end{array}$ & $\begin{array}{c}1.2 \\
(4.0)\end{array}$ & 100 \\
\hline 8 & $\begin{array}{c}566.9-568.6 \\
(1,860.0-1.865 .5)\end{array}$ & $\begin{array}{c}1.7 \\
(5.5)\end{array}$ & 100 \\
\hline 9 & $\begin{array}{c}624.8-627.3 \\
(2,050.0-2,058.0)\end{array}$ & $\begin{array}{l}2.4 \\
(8.0)\end{array}$ & 100 \\
\hline 10 & $\begin{array}{c}655.3-657.1 \\
(2,150.0-2,156.0)\end{array}$ & $\begin{array}{l}1.8 \\
(6.0)\end{array}$ & 100 \\
\hline
\end{tabular}


Appendix D

Geophysical Logs 



\section{Geophysical Logs}

Appendix D contains presentations of selected geophysical logs run during recompletion operations. Table D-1 summarizes the logs presented on the following charts. Table D-2 contains a list of geophysical logs run in 1965 through 1983, prior to recompletion activities.

See Table 3-2 in the main body of this report for more information on logs run in Well UE-10j.

Table D-1

Geophysical Log Summary for Well UE-10j

\begin{tabular}{|c|c|c|c|}
\hline Log Type & $\begin{array}{l}\text { Log Interval } \\
\text { Meters (feet) }\end{array}$ & $\begin{array}{c}\text { Run } \\
\text { Number }\end{array}$ & Run Date \\
\hline Caliper & $\begin{array}{c}0.00-668.3(0.0-2,192.5) \\
668.4-774.2(2,192.8-2,540.0)\end{array}$ & $\begin{array}{l}\text { CA6-4 } \\
\text { CA6-6 }\end{array}$ & $\begin{array}{l}02 / 12 / 1993 \\
10 / 27 / 1993 \\
\end{array}$ \\
\hline $\begin{array}{l}\text { Density } \\
\text { (Compensated Densilog) }\end{array}$ & $646.3-775.4 \quad(2,120.3-2,544.0)$ & CDL-1 & 03/04/1993 \\
\hline $\begin{array}{l}\text { Digital Spectralog } \\
\text { Spectral Potassium } \\
\text { Spectral Uranium } \\
\text { Spectral Thorium }\end{array}$ & $660.0-773.5(2,165.3-2,537.8)$ & SGR-2 & 03/04/1993 \\
\hline $\begin{array}{l}\text { Gamma Ray } \\
\text { Digital Spectralog and } \\
\text { Compensated Neutron }\end{array}$ & $\begin{array}{ll}768.4-773.6 & (2,521.0-2,538.0) \\
647.7-768.3 & (2,125.0-2,520.8)\end{array}$ & $\begin{array}{l}\text { SGR-2 } \\
\text { CN-2 }\end{array}$ & $\begin{array}{l}03 / 04 / 1993 \\
03 / 04 / 1993\end{array}$ \\
\hline $\begin{array}{l}\text { Porosity } \\
\text { (Compensated Neutron) }\end{array}$ & $646.3-775.4(2,120.3-2,544.0)$ & $\mathrm{CN}-1$ & 03/04/1993 \\
\hline $\begin{array}{l}\text { Resistivity } \\
\text { (Dual Lateralog) }\end{array}$ & $661.4-772.7(2,170.0-2,535.0)$ & DLL-1 & 03/04/1993 \\
\hline $\begin{array}{l}\text { Spontaneous Potential } \\
\text { (Dual Lateralog) }\end{array}$ & $661.4-772.7(2,170.0-2,535.0)$ & DLL-1 & 03/04/1993 \\
\hline Temperature & $\begin{array}{ll}631.1-701.0 & (2,070.5-2,300.0) \\
701.1-739.1 & (2,300.3-2,425.0) \\
739.2-772.9 & (2,425.3-2,535.8) \\
\end{array}$ & $\begin{array}{l}\text { TL-1 } \\
\text { TL-2 } \\
\text { TL-5 }\end{array}$ & $\begin{array}{l}03 / 03 / 1993 \\
04 / 14 / 1993 \\
11 / 16 / 1993 \\
\end{array}$ \\
\hline
\end{tabular}


Table D-2

Summary of Geophysical Logs Run in Well UE-10j, 1965 to 1983

\begin{tabular}{|c|c|c|c|c|c|}
\hline $\begin{array}{c}\text { Geophysical Log } \\
\text { Type }\end{array}$ & $\begin{array}{l}\text { Logging } \\
\text { Service }\end{array}$ & $\begin{array}{l}\text { Date } \\
\text { Logged }\end{array}$ & $\begin{array}{l}\text { Run } \\
\text { Number }\end{array}$ & $\begin{array}{c}\text { Top of Logged } \\
\text { Interval (bgs a }) \\
\text { Meters (feet) } \\
\end{array}$ & $\begin{array}{l}\text { Bottom of Logged } \\
\text { Interval (bgs) } \\
\text { Meters (feet) }\end{array}$ \\
\hline Borehole Gravity & $\begin{array}{l}\text { USGS }^{b} \\
\text { LLL }^{c} \\
\end{array}$ & $\begin{array}{l}08 / 07 / 1976 \\
01 / 18 / 1977 \\
\end{array}$ & $\begin{array}{l}1 \\
1 \\
\end{array}$ & $\begin{array}{c}0.3(1) \\
?\end{array}$ & $\begin{array}{c}481.6(1,580) \\
?\end{array}$ \\
\hline $\begin{array}{l}\text { Borehole Deviation } \\
\text { Survey (gyroscopic } \\
\text { multi-shot) }\end{array}$ & $\begin{array}{l}S^{d} \\
S S\end{array}$ & $\begin{array}{l}05 / 26 / 1965 \\
08 / 31 / 1976\end{array}$ & $\begin{array}{c}1,2 \\
1\end{array}$ & $\begin{array}{c}0(0) \\
198.1(650)\end{array}$ & $\begin{array}{l}726.0(2,382) \\
481.6(1,580)\end{array}$ \\
\hline Caliper & $\begin{array}{l}\text { Welex } \\
\text { BWS } \\
\text { BWS }\end{array}$ & $\begin{array}{l}05 / 25 / 1965 \\
03 / 02 / 1976 \\
04 / 11 / 1976 \\
\end{array}$ & $\begin{array}{l}\text { CA6-1 } \\
\text { CA6-1 } \\
\text { CA6-2 }\end{array}$ & $\begin{array}{ll}9.1(30) \\
4.6(15) \\
9.1(30) \\
\end{array}$ & $\begin{array}{ll}725.1 & (2,379) \\
700.1 & (2,297) \\
691.6 & (2,269) \\
\end{array}$ \\
\hline Density & $\begin{array}{l}\text { Welex } \\
\text { BWS } \\
\text { BWS }\end{array}$ & $\begin{array}{l}05 / 25 / 1965 \\
06 / 24 / 1976 \\
07 / 22 / 1976 \\
\end{array}$ & $\begin{array}{c}1 \\
\text { FDD-1 } \\
\text { FDD-2 }\end{array}$ & $\begin{array}{cl}18.3(60) \\
0 & (0) \\
9.1 & (30) \\
\end{array}$ & $\begin{array}{ll}724.8 & (2,378) \\
691.6 & (2,269) \\
694.3 & (2,278) \\
\end{array}$ \\
\hline Fluid Density & $\begin{array}{l}\text { Welex } \\
\text { Welex } \\
\text { BWS } \\
\text { BWS }\end{array}$ & $\begin{array}{l}05 / 27 / 1965 \\
05 / 27 / 1965 \\
03 / 02 / 1976 \\
06 / 24 / 1976 \\
\end{array}$ & $\begin{array}{l}\text { DF-1 } \\
\text { DF-2 } \\
\text { DF-3 } \\
\text { DF-4 }\end{array}$ & $\begin{array}{ll}320.0 & (1,050) \\
612.6 & (2,010) \\
548.6 & (1,800) \\
609.6 & (2,000) \\
\end{array}$ & $\begin{array}{ll}640.1 & (2,100) \\
640.1 & (2,100) \\
699.2 & (2,294) \\
691.6 & (2,269) \\
\end{array}$ \\
\hline Gamma Ray/Neutron & Welex & $05 / 25 / 1965$ & 1 & $0(0)$ & $725.4(2,380)$ \\
\hline Gamma Ray & BWS & $09 / 20 / 1981$ & GR-1 & $0(0)$ & $442.6(1,452)$ \\
\hline Induction & BWS & 05/18/1979 & IEL-1A & $17.1(56)$ & $685.5(2,249)$ \\
\hline Spectralog & $D^{f}{ }^{f}$ & $04 / 29 / 1983$ & SGR-1 & $0(0)$ & $442.9(1,453)$ \\
\hline $\begin{array}{l}\text { Total Magnetic } \\
\text { Intensity }\end{array}$ & LLL & 08/16/1979 & 1 & $19.8(65)$ & $350.5(1,150)$ \\
\hline Vibroseis & BWS & $04 / 11 / 1976$ & 1 & $18.9(62)$ & $695.2(2,281)$ \\
\hline
\end{tabular}

\footnotetext{
a below ground surface

b U.S. Geological Survey

c Lawrence Livermore Laboratory

d Sperry-Sun

e Birdwell Wireline Services

f Dresser Atlas
} 


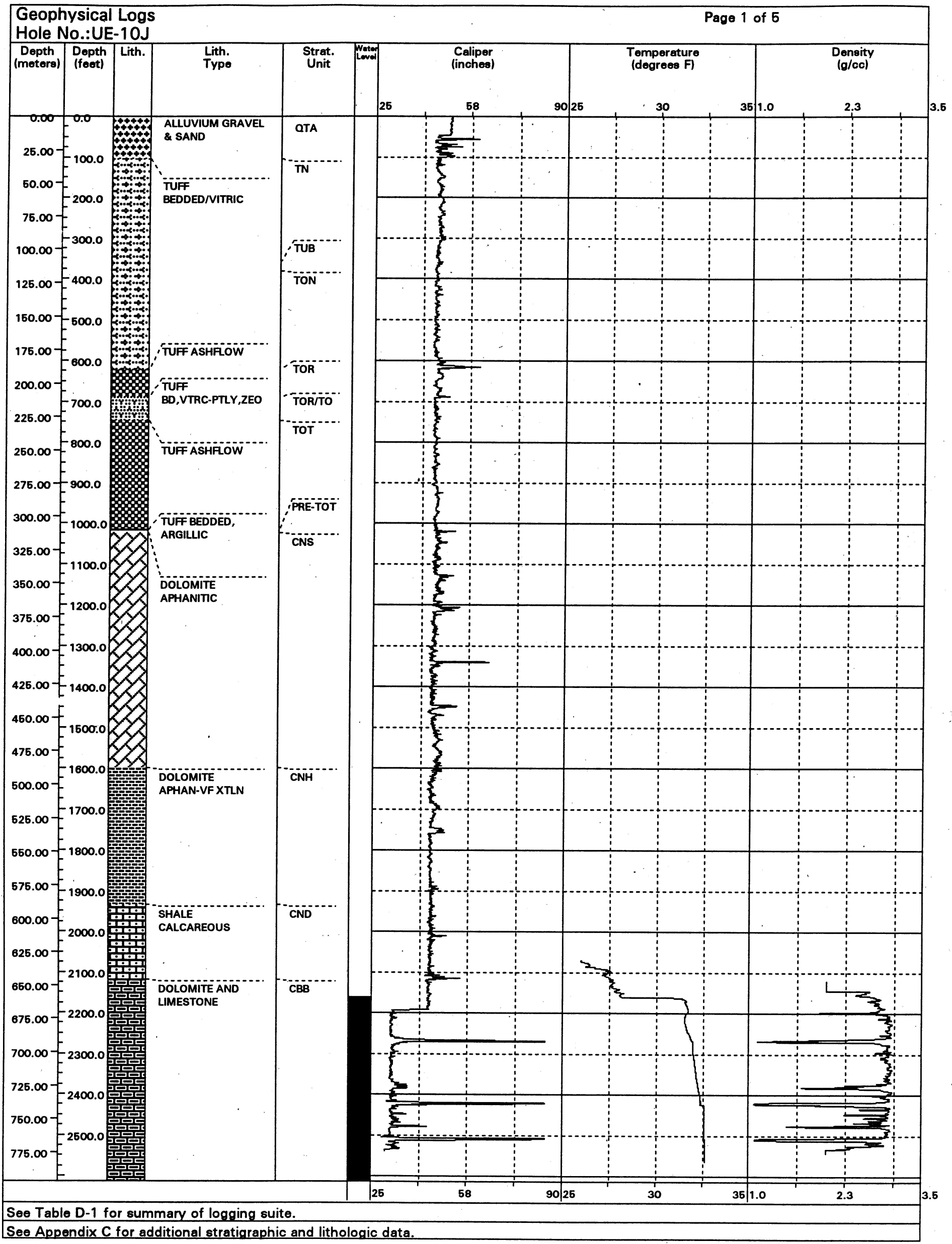

D-3 


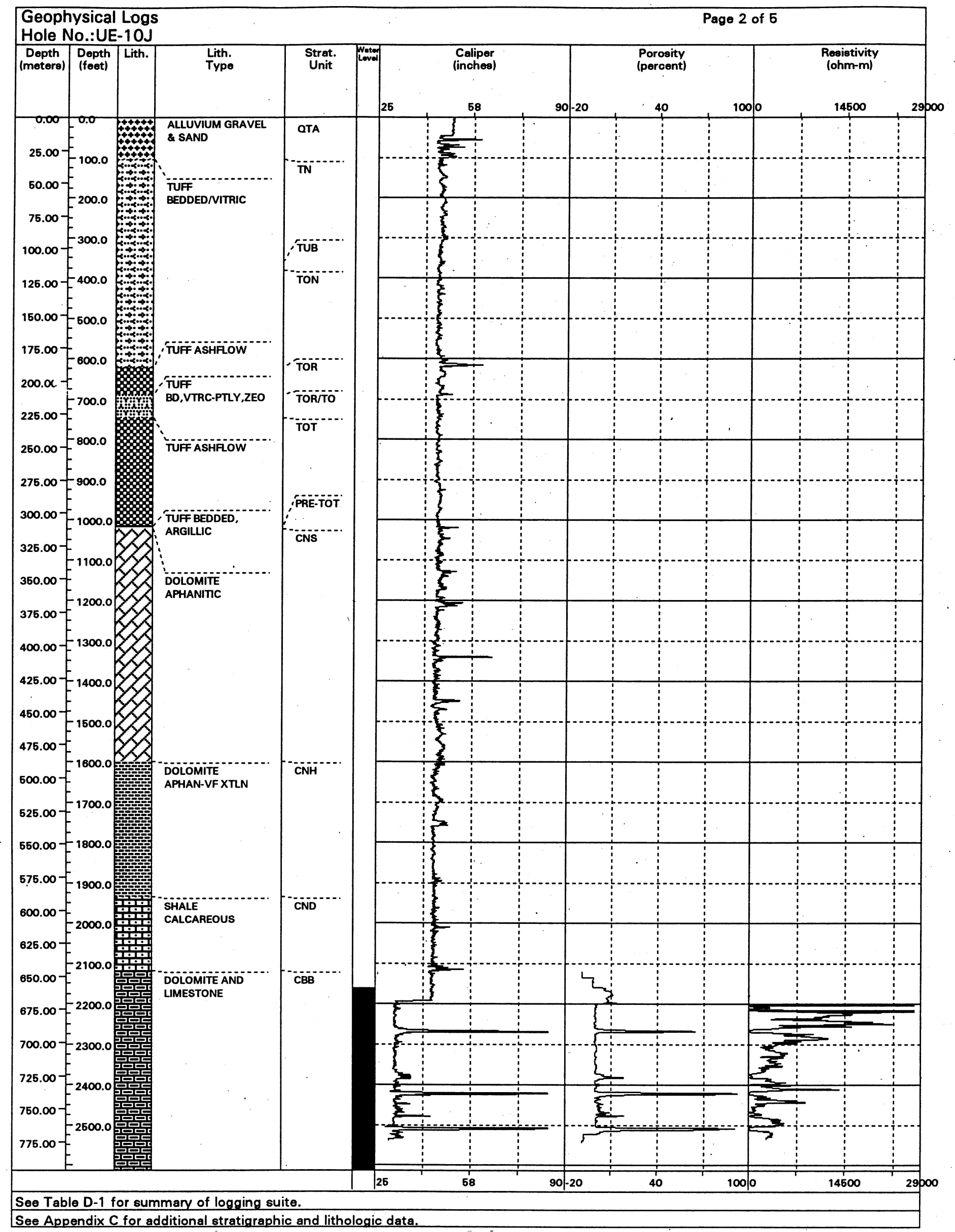




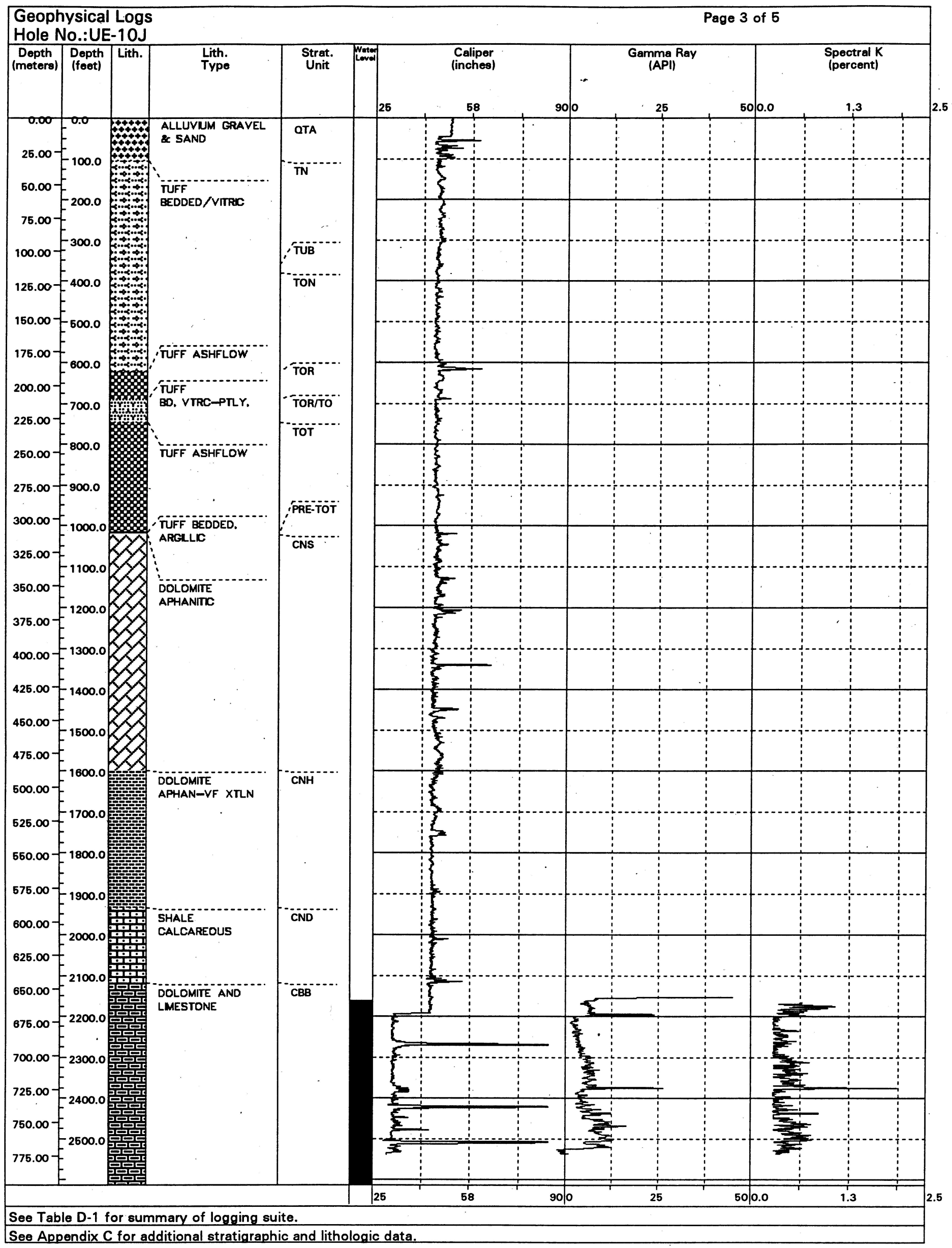

D-5 


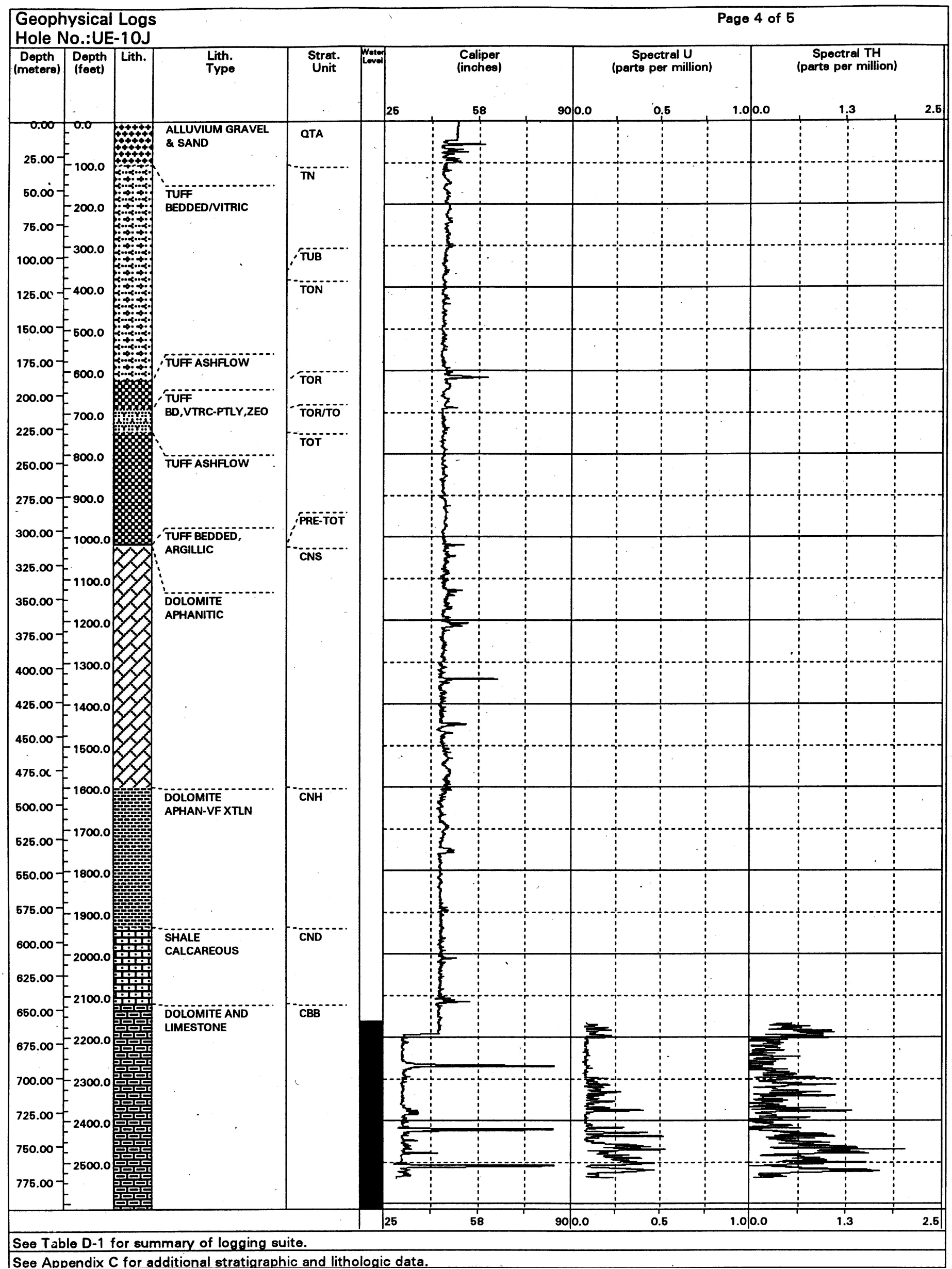




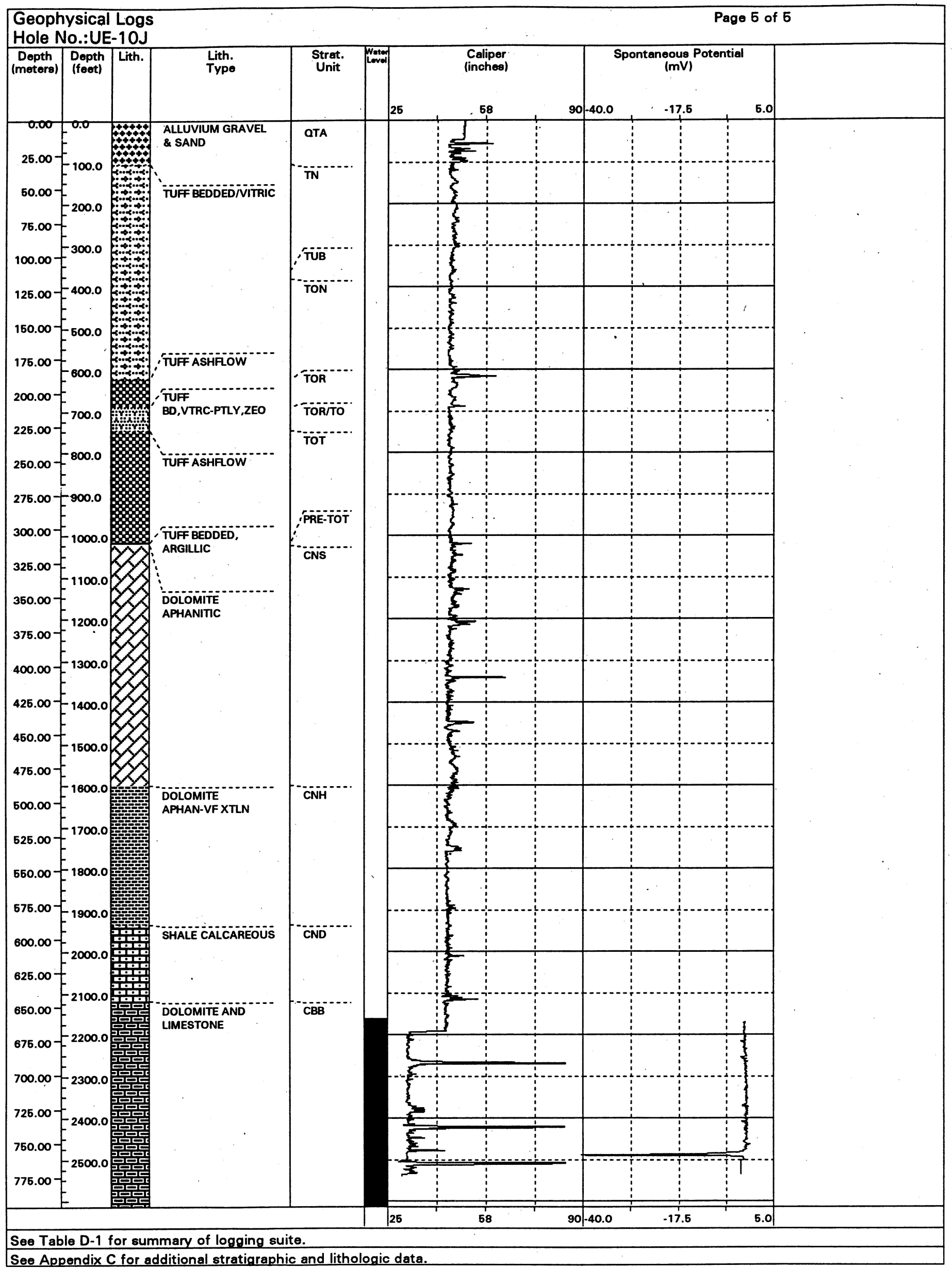

D-7 
This page intentionally left blank.

D-8 


\section{Distribution List}

\section{$\underline{\text { Copies }}$}

R. M. Bangerter

Environmental Restoration Division

DOE Nevada Operations Office

P.O. Box 98518, M/S 505

Las Vegas, NV 89193-8518

U.S. Department of Energy

Nevada Operations Office

Technical Information Resource Center

P.O. Box 98518

Las Vegas, NV 89193-8518

U.S. Department of Energy

Nevada Operations Office

Public Reading Facility

P.O. Box 98521

Las Vegas, NV 89193-8521

U.S. Department of Energy

Office of Scientific and Technical Information

P.O. Box 62

Oak Ridge, TN 37831-0062

D. W. Duncan

Environment, Safety, and Health Division

DOE/Nevada Operations Office

P.O. Box 98518, M/S 505

Las Vegas, NV 89193-8518

P. K. Ortego

Bechtel Nevada

P.O. Box 98521, M/S NLV082

Las Vegas, NV 89193-8521

Janet Wille

IT Corporation

P. O. Box 93838, M/S 439

Las Vegas, NV 89193-3838

IT Library

IT Corporation

P. O. Box 93838, M/S 439

Las Vegas, NV 89193-3838 
W. L. Hawkins

Los Alamos National Laboratory

P.O. Box 1663

Los Alamos, NM 87545-1663

D. L. Finnegen

Los Alamos National Laboratory

P. O. Box 1663

Los Alamos, NM 87545-1663

G. A. Pawloski

Lawrence Livermore National Laboratory

P.O. Box 808

Livermore, CA 94550-0808

D. K. Smith

Lawrence Livermore National Laboratory

P.O. Box 808

Livermore, CA 94550-0808

B. K. Thompson

DOE/USGS Cooperative Program Manager

U.S. Geological Survey

Water Resources Division

6770 S. Paradise Rd.

Las Vegas, NV 89119-3721

C. E. Russell

1

Desert Research Institute

P.O. Box 19040

Las Vegas, NV 89119-7363 